Portland State University

PDXScholar

Master of Environmental Management Project

Reports

Environmental Science and Management

Spring 2003

\title{
Urbanization and its Relationship to Water Quality within the Bronson Creek Watershed
}

Jason Cristopher Creech

Portland State University

Follow this and additional works at: https://pdxscholar.library.pdx.edu/mem_gradprojects

Part of the Environmental Indicators and Impact Assessment Commons, and the Natural Resources Management and Policy Commons

Let us know how access to this document benefits you.

\section{Recommended Citation}

Creech, Jason Cristopher, "Urbanization and its Relationship to Water Quality within the Bronson Creek Watershed" (2003). Master of Environmental Management Project Reports. 8.

https://pdxscholar.library.pdx.edu/mem_gradprojects/8

https://doi.org/10.15760/mem.37

This Project is brought to you for free and open access. It has been accepted for inclusion in Master of Environmental Management Project Reports by an authorized administrator of PDXScholar. Please contact us if we can make this document more accessible: pdxscholar@pdx.edu. 


\title{
Urbanization and its Relationship to Water Quality within the Bronson Creek Watershed
}

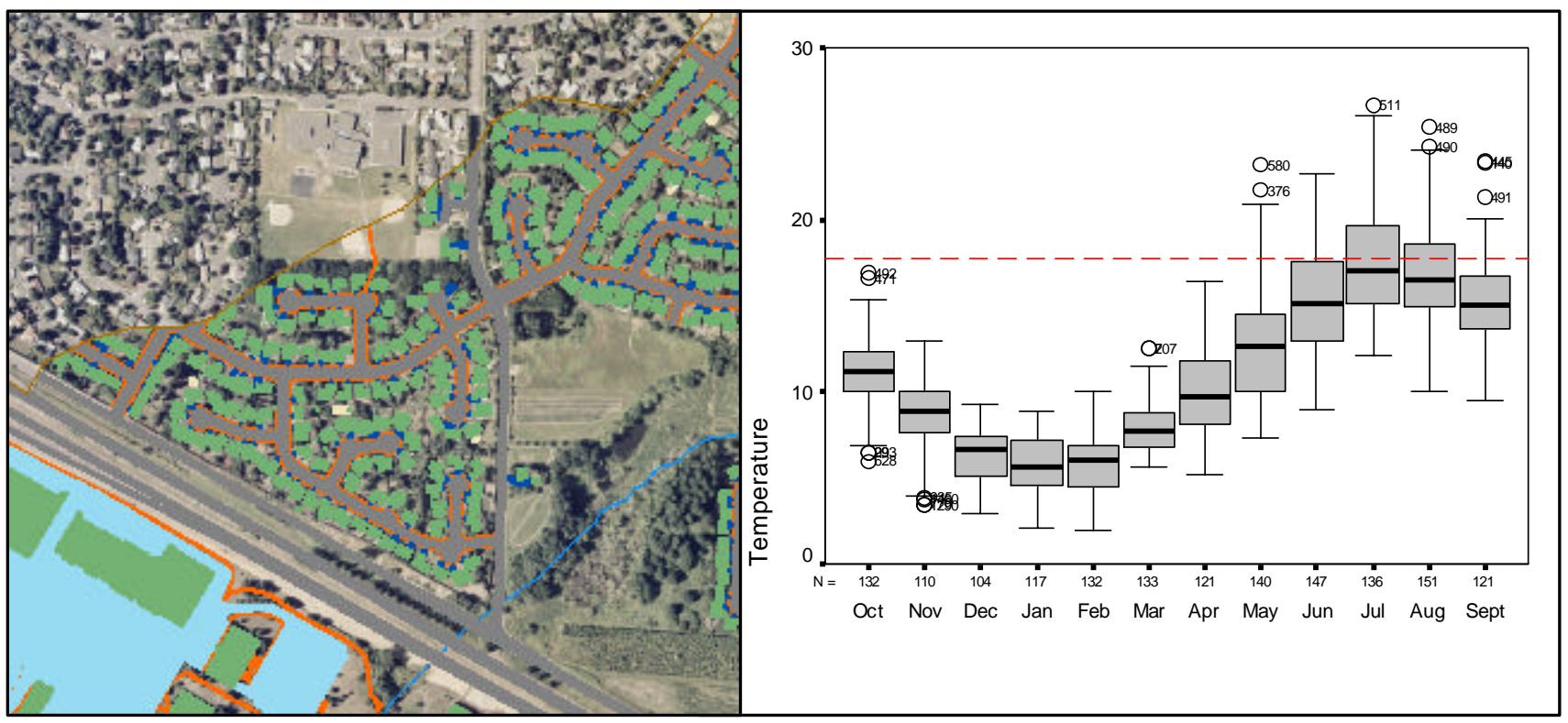

\author{
Jason Creech \\ Portland State University \\ Portland, Oregon
}




\title{
Urbanization and its Relationship to Water Quality within the Bronson Creek Watershed
}

\author{
By \\ Jason Christopher Creech
}

A project report submitted in partial fulfillment of the requirements for the degree of

Master of Environmental Management in

Environmental Sciences and Resources

Portland State University

2003 


\section{PROJECT REPORT APPROVAL}

The abstract and project report of Jason Christopher Creech for the Master of Environmental Management in Environmental Sciences and Resources were presented June 12, 2003, and accepted by the project committee and the department.

COMMITTEE APPROVALS:

Dr. Roy Koch, Advisor

Portland State University

Bernie Bonn

Clean Water Services

Dr. Heejun Chang

Portland State University

DEPARTMENT APPROVAL:

Dr. Roy Koch, Chair

Department of Environmental Sciences and Resource 


\begin{abstract}
Urbanization and its Relationship to Water Quality within the Bronson Creek Watershed
\end{abstract}

A watershed analysis project was undertaken to investigate the impact of urbanization on the water quality with Bronson Creek; a small urban stream in the metropolitan area of Portland, Oregon. Total Maximum Daily Loads (TMDLs) have been established for several water quality parameters within the watershed.

Water quality data were collected at nine sampling along Bronson Creek by Clean Water Services, a local public utility charged with storm water management and water quality protection duties. Only seven water quality parameters were included in the analysis; they were 1) temperature, 2) total phosphorous, 3) ortho-phosphate, 4) ammonia, 5) total nitrogen, 6) total suspended solids, and 7) E. Coli. Samples were taken approximately twice a month over a 7 year period from $1994-2001$.

Total impervious area (TIA) was used as the indicator of urbanization for the project. Impervious area values (TIA\%) were calculated by digitizing aerial photography. Yearly TIA values were calculated for the entire watershed, as well as for its 37 subasins (subcatchement level). 
Water quality data were analyzed for variations along the stream and for the presence of trends (monotonic changes over time) during seasons of poor water quality. Kendall's t was also used as the trend test statistic. Data were also analyzed to determine if an association exists between water quality at a sampling site and the upstream imperviousness (TIA\%). Kendall's t was used as the test statistic.

Negative trends (improving water quality) were found throughout the watershed with nitrogen exhibiting the largest reduction. Temperature was the only parameter not to exhibit a negative trend at any location within the watershed. Results of the correlation between water quality and TIA\% showed similar results, where a parameter experiencing a trend also exhibited a significant Kendall's correlation with upstream TIA\%. As TIA increased, water quality improved at least one site, for all parameters except temperature.

One possible cause of the improving water quality within Bronson Creek is the implementation of best management practices within the watershed. Stormwater ponds were located in subcatchments that were adjacent to water quality sampling sites with improving water quality. The Bronson Creek watershed is also part of a pilot program to test the effectiveness of best management practices on improving water quality in the urban environment. 


\section{Acknowledgments}

I would like to thank Dr. Roy Koch for his guidance and counsel during this project. His insight and knowledge of statistical methods were invaluable. I would also like to thank Bernie Bonn and Jan Miller from Clean Water Services for there assistance in putting this project together. Their knowledge of the water quality data and water resource management practices within Bronson Creek watershed was extremely helpful. Finally, I would like to thank Erin Mick and Michael Mintz for their diligence in digitizing the impervious surfaces within Bronson Creek Watershed. The tedious nature of the work required a special work ethic and I'm delighted that they were on the team.

I would also like to thank Clean Water Services, for funding this project. I would not have been able to complete the degree program without there financial assistance. I am truly indebted. 


\section{TABLE OF CONTENTS}

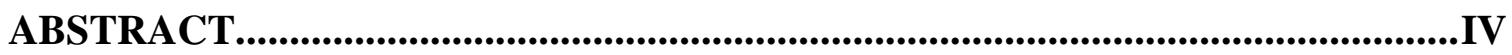

ACKNOWLEDGMENTS.......................................................................................VI

LIST OF FIGURES …........................................................................................................VIII

LIST OF TABLES ….................................................................................................VIII

I. INTRODUCTION ....................................................................................................

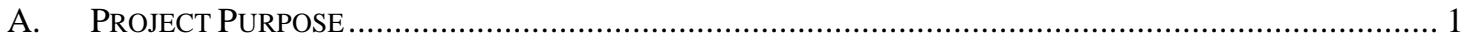

B. IMPACTS OF URBANIZATION ON WATER QUALITY .................................................... 1

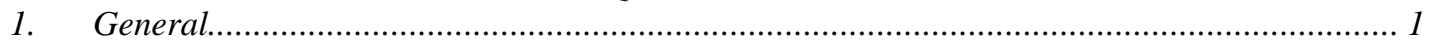

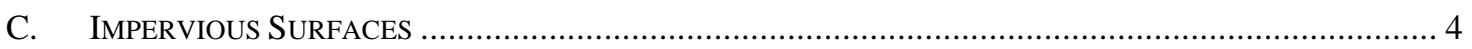

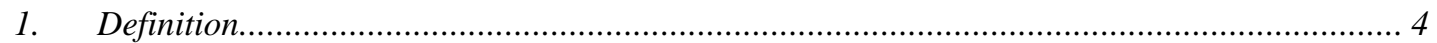

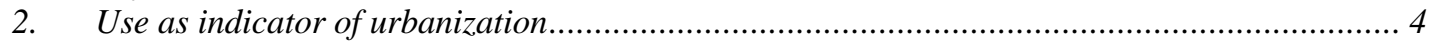

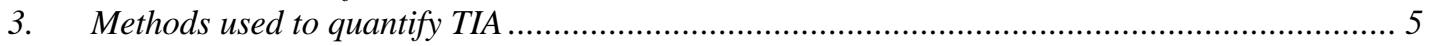

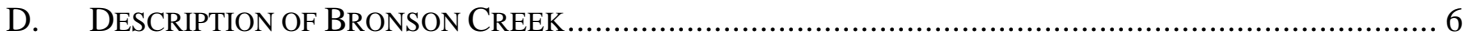

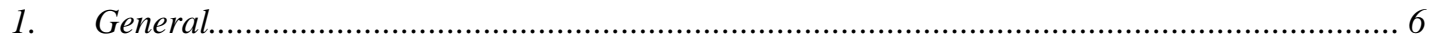

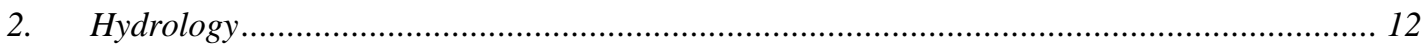

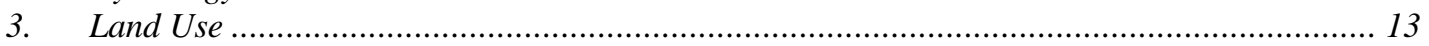

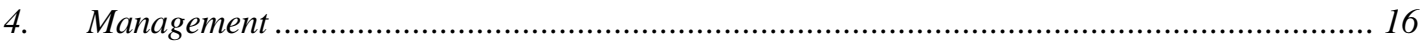

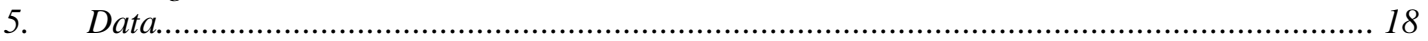

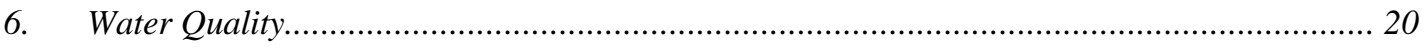

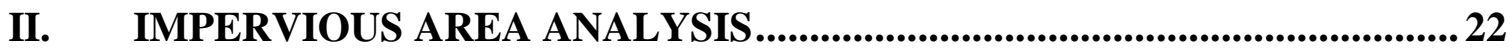

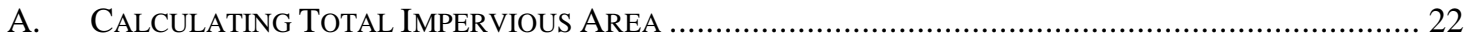

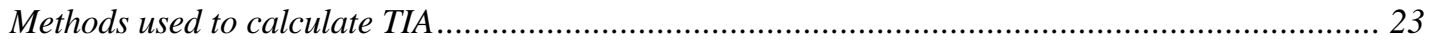

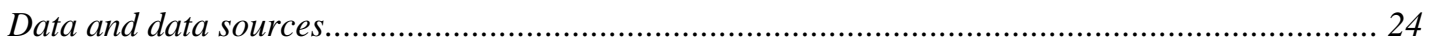

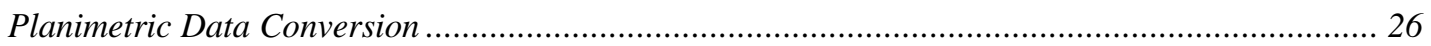

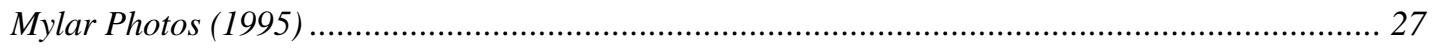

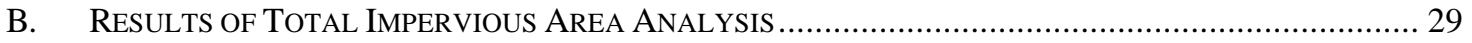

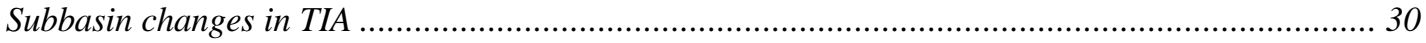

Changes in specific impervious features........................................................................... 34

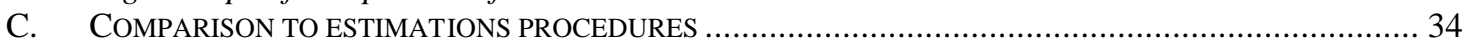

Comparison of TIA values calculated from differing methods .................................................. 35

Results of Estimation Analysis ........................................................................................ 39

III. WATER QUALITY ANALYSIS ........................................................................ 42

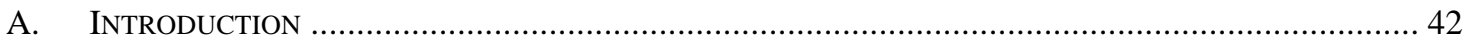

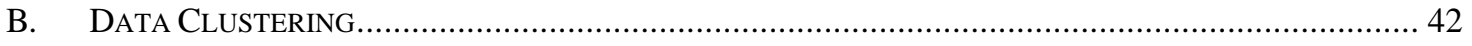

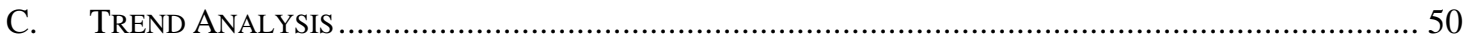

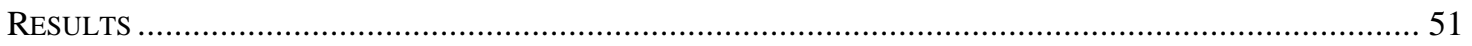

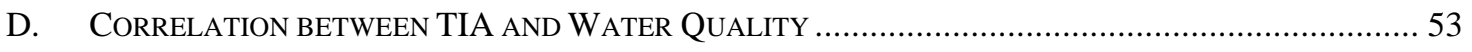

IV. IMPLICATIONS AND RECOMMENDATIONS .......................................58

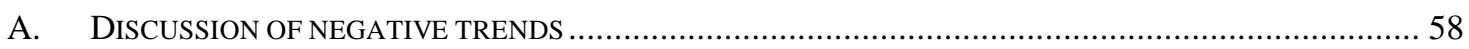

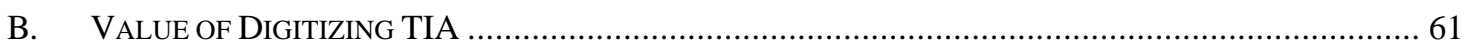

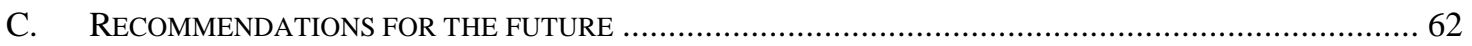

APPENDIX A: SPSS ANOVA OUTPUT FOR MONTHLY ANALYSIS ............... 68 


\section{APPENDIX B: SPSS ANOVA OUTPUT FOR DOWNSTREAM ANALYSIS.........76 APPENDIX C: DIGITAL GIS DATA AND REPORT

\section{List of Figures}

FIgURE 1 OVERVIEW MAP OF BRONSON CREEK WATERSHED................................................ 8

FIGURE 2 MIDDLE TUALATIN WATERSHED HYDROLOGIC UNITS ............................................... 9

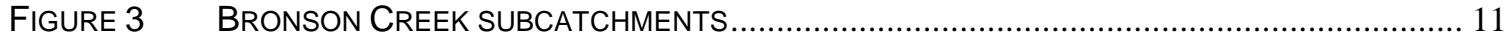

FIGURE $4 \quad$ BRONSON CREEK HYDROGRAPH AT WEST UNION .................................................... 13

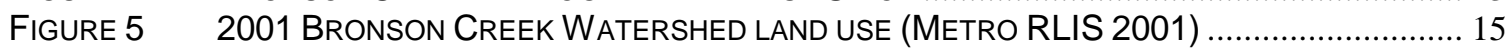

FIGURE 6 MAP OF BRONSON CREEK SAMPLING SITES............................................................... 20

FIGURE 8 INCREASE IN IMPERVIOUS AREA, AS A PERCENTAGE OF THE TOTAL BASIN AREA, FOR THE

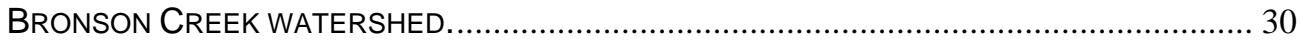

FIGURE 92001 BRONSON TIA\% AND TIA CHANGE FROM 1994 - 2001 ...................................... 32

FIGURE 10 COMPARISON OF METHODS USED TO CALCULATE TOTAL IMPERVIOUS SURFACE AREA..... 41

FIGURE 11 MULTIPLE COMPARISON OUTPUT FOR TEMPERATURE ….............................................. 45

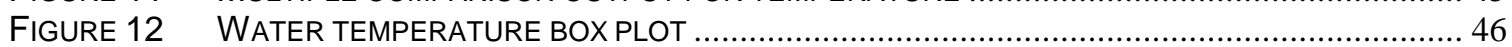

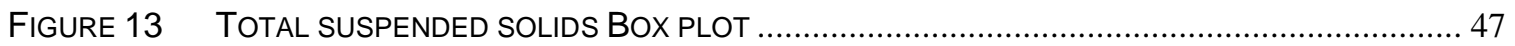

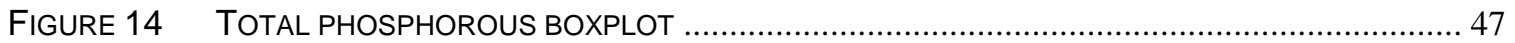

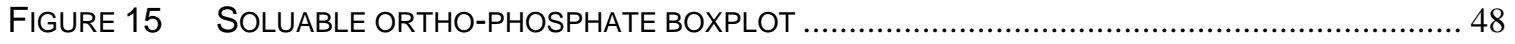

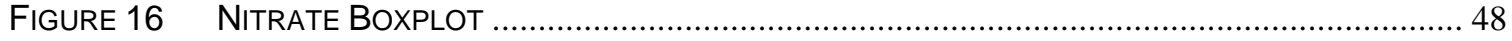

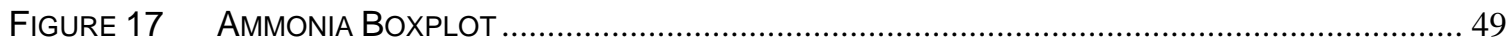

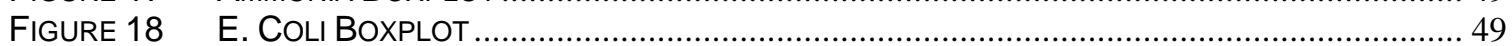

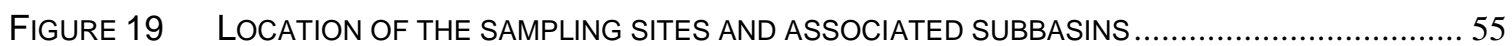

FIGURE 20 STROMWATER FACILITIES WITHIN BRONSON CREEK WATERSHED ................................... 60

\section{List of Tables}

TABLE 1 IMPACTS FROM INCREASES IN IMPERVIOUS SURFACES (USEPA 1997) ........................... 3

TABLE 2 BRonson CREek WATERSHEd (CATCHMENT) HUC ADDRESS (REO 2003B)................. 10

TABLE $3 \quad$ DESCRIPTION OF THE VARIOUS WATERSHED MANAGEMENT UNITS ................................ 12

TABLE $4 \quad 2001$ BRONSON CREEK WATERSHED LAND USE STATISTICS …….................................... 14

TABLE 5 ACTIVE TMDLS WITHIN THE TUALATIN WATERSHED (FROM ODEQ 2001) ........................ 18

TABLE 6 PROJECT VARIABLES, CRITICAL LEVELS AND MINIMUM DETECTION LIMITS........................ 19

TABLE 7 FORMAT, SOURCE AND RESOLUTION OF AERIAL PHOTOGRAPHY .................................... 24

TABLE 8 TOTAL IMPERVIOUS AREA FROM 1994 THROUGH 2001 IN THE BRONSON CREEK

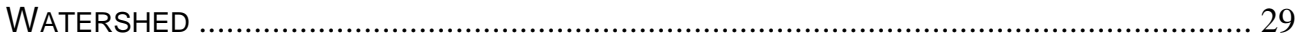

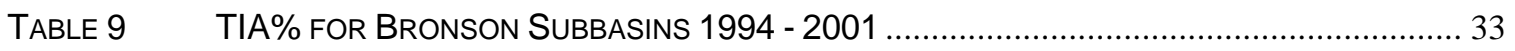

TABLE 10 PERCENT OF IMPERVIOUS AREA BY CATEGORY WITHIN THE BRONSON CREEK

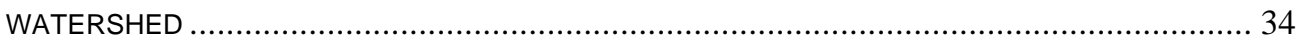

TABLE 11 IMPERVIOUSNESS VALUES ASSIGNED TO RLIS LAND USE CLASSIFICATIONS...................... 37

TABLE 12 RESULTS OF COMPARISON OF DIGITIZED TIA AND TIA ESTIMATED FROM LAND USE....... 40

TABLE 13 CLUSTERS AND METHOD FOR EACH VARIABLE ........................................................... 50

TABLE $14 \quad$ ASSOCIATION BETWEen WATER QuALITY AND TIME (TREND) ........................................ 52

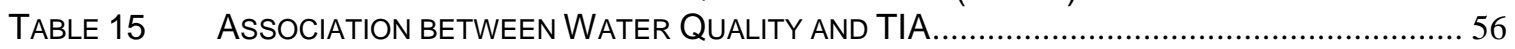




\section{Introduction}

\section{A. Project Purpose}

The purpose of this project was to assess whether urbanization within Bronson Creek watershed has impacted the water quality of Bronson Creek over the past decade. Total Impervious Area (TIA), an indicator of urbanization, was calculated for the watershed for each year between 1994 and 2001. These values were then statistically compared to water quality samples to determine if such a relationship exists.

\section{B. Impacts of Urbanization on Water Quality}

\section{General}

Over the past few decades, the impacts of urbanization on watershed health have been thoroughly investigated and documented (Klien 1979; Booth 1991). The adverse affects of watershed development include the transformation of the natural hydrologic flow regime, changes in stream temperature, and decreased water quality (Klien 1979).

Increasing imperviousness increases runoff and decreases infiltration, resulting in higher peak flows and lower base flows (Klien 1979). Booth (1991) states that urbanization does more than magnify peak flows. Small storms that would not typically produce a peak event do so in urbanized watersheds. Leopold's (1968) classic paper on the effect of urbanization on the surrounding hydrologic cycle included four key impacts of urbanization to hydrology: 1) changes in peak flows, 2) changes in the quantity of runoff, 3) changes in water quality, and 4) visual impacts to the stream channel. 


\section{Temperature}

Stream temperature is also altered by urbanization with several processes contributing to the changes. One major contributor involves the function of the riparian corridor or buffer that surrounds most natural streams. As watersheds are developed, the natural stream bank shape and vegetative cover are modified. Vegetation may be removed during the construction of sewer lines or other facilities in or near a stream or the stream channel itself may be relocated to follow an entirely new path. These activities reduce the amount of shade that a stream receives and also leave a wider and shallower stream bed, both of which affect the normal thermal regime of the stream (Klien 1977). Reduction in baseflow, another impact of urbanization, can also affect stream temperature. As urbanization is increased, solar radiation is absorbed and reflected from urban structures, which result in increased temperatures in the microclimate. The increased ground and air temperatures subsequently raise the temperature of nearby streams (Schuler and Holland 2000b).

\section{$\underline{\text { Nutrients }}$}

Water quality is also impaired by urbanization. Impervious surfaces provide a direct pathway for nutrients and toxins to flow into surface waters (Schuler and Holland 2000b). Urban runoff typically contains nutrients such as nitrogen and phosphorous. Sources include runoff of lawn fertilizer, pet waste, failing septic systems and deposition of atmospheric emissions (USEPA 2002). 


\section{Sediment}

Impacts to surface waters from sediment are a great concern throughout the United States (USEPA 2002). Sediment sources include construction activities, agricultural erosion, grazing, deforestation, as well as the erosion of the stream bank or the incision of the stream channel (USEPA 2002). Major impacts of sediment include the loss of habitat or spawning grounds, smothering of benthic organisms, disruption to the food chain, and changes to the natural hydraulic regime of streams (Schuler and Holland 2000b).

In 2001, Clean Water Services recognized six site specific problems impacting water quality within the Tualatin Basin. Impervious surfaces were included on this list with other common impacts to water quality such as golf courses, grazing, construction/ development, landscaping and nurseries. An impervious area taskforce was established in 2000 to address impacts of impervious and implement best management practices to reduce the amount of effective impervious area within the basin (CWS 2001a). Table 1 summarizes many of the impacts to stream health or water quality as defined by the Unites States Environmental Protection Agency.

Table 1 Impacts from increases in impervious surfaces (USEPA 1997)

\begin{tabular}{|c|c|c|c|c|c|}
\hline \multirow{2}{*}{$\begin{array}{c}\text { Increased } \\
\text { Imperviousness Leads to: }\end{array}$} & \multicolumn{5}{|c|}{ Resulting Impacts } \\
\cline { 2 - 6 } & Flooding & $\begin{array}{c}\text { Habitat } \\
\text { Loss }\end{array}$ & Erosion & $\begin{array}{c}\text { Channel } \\
\text { Widening }\end{array}$ & $\begin{array}{c}\text { Streambed } \\
\text { Alteration }\end{array}$ \\
\hline Increased Volume & $?$ & $?$ & $?$ & $?$ & $?$ \\
\hline Increased Peak Flow & $?$ & $?$ & $?$ & $?$ & $?$ \\
\hline Increased Peak Duration & $?$ & $?$ & $?$ & $?$ & $?$ \\
\hline Increased Stream Temperature & & $?$ & & & $?$ \\
\hline Decreased Base Flow & & $?$ & & & $?$ \\
\hline Sediment Loading Changes & $?$ & $?$ & $?$ & & $?$ \\
\hline
\end{tabular}




\section{Impervious Surfaces}

\section{Definition}

"Urbanization has resulted in increased impervious surface area, which in turn has increased peak flows to streams, increased delivery of pollutants to these streams, and resulted in downcutting of stream channels." (Hawksworth 2001) As a watershed is urbanized, natural ground cover is replaced by manmade structures, such as buildings, roads, and parking lots. These features are considered impervious surfaces because they prevent or decrease the natural infiltration of precipitation (Schueler 1994).

\section{Use as indicator of urbanization}

Impervious surface area has become a valuable index used to quantify urbanization. Arnold and Gibbons (1996) suggest that its utility stems from two factors. The first being that imperviousness is quantifiable. The impervious surface area within a watershed can be measured and analyzed through several techniques. The second factor is that imperviousness is an integrative value that can be used in watershed management and analysis. Impervious cover has been used as an index of urbanization in many published articles (Klien 1979, Booth 1991, Arnold and Gibbons 1996).

In general, the imperviousness of a watershed is reported as percent impervious, also known as total impervious area (TIA). Threshold values have been calculated to identify 
the degree of impairment for a watershed. Studies have shown the initial impairment value to be around 10 percent total impervious area (Klien 1979, Schueler 1994).

\section{Methods used to quantify TIA}

Two metrics are available to report the amount of impervious cover within a watershed. Impervious surface can be quantified using 1) total impervious area (TIA) or 2) effective impervious area (EIA). TIA represents all actual impervious area within a watershed and there is no distinction between the hydraulic function of individual impervious features (Equation 1). In contrast, EIA characterizes only that impervious cover that flows directly to the drainage system (Alley and Veenhuis 1983).

\section{Total Impervious Area}

$$
T I A=\frac{\text { Impervious Area }}{\text { Total Area }} \times 100
$$

EIA is the portion of the total watershed impervious area that is directly connected to the drainage network. EIA attempts to account for the fact that the hydrologic impact of impervious surfaces vary with the connectivity of impervious surfaces to the surface water drainage network. An impervious surface that is disconnected and drains to a permeable surface does not truly act as an impervious surface (Sutherland 2000).

EIA represents that portion of the TIA that is directly connected to the basin outlet by the storm sewer system. Therefore, if all impervious surfaces are hydraulically connected to a stream, the effective impervious area is equal to the total impervious area. Sutherland recommends converting total impervious area to effective impervious area by using one 
of five available equations (Sutherland 2000). Each of the equations is designed to account for the average hydraulic connectivity of the watershed (Equation 2-5).

\section{Average conditions}

$E I A=0.1(T I A)^{1.5}$, TIA $=1$

Highly connected basins

$E I A=0.4(T I A)^{1.2}, T I A=1$

Totally connected basins

$E I A=T I A$

Somewhat connected basins

$E I A=0.04(T I A)^{1.7}$, TIA $=1$

\section{Extremely connected basins}

$E I A=0.01(T I A)^{2.0}, T I A=1$

\section{Description of Bronson Creek}

\section{General}

The Bronson Creek Watershed is as small urban watershed that lies within the Metropolitan area of Portland Oregon (Figure 1). The watershed drains both Bronson Creek and Bannister Creek, a small tributary of Bronson Creek, to Beaverton Creek, which eventually flows to the Tualatin River via Rock Creek. The Bronson Creek watershed drains approximately 3195 acres (619 acres for Bannister Creek and 2576 acres for Bronson Creek) through a variety of land uses. The watershed lies within 
Multnomah and Washington counties and parts of Beaverton and Hillsboro's city limits are with the watershed.

Though it is called a watershed, the land area that drains to Bronson Creek is actually a catchment as defined by the USGS's updated hydrologic unit code classification system (Koski, M., C. Novak, et al. 2001). The catchment level of classification corresponds to a $7^{\text {th }}$ field watershed with a 14-digit HUC address (Table 2). At this time the USGS has only defined the $6^{\text {th }}$ field subwatersheds in the Tualatin basin (REO 2003a). Figure 2 displays the Bronson Creek subcatchment in relation to other Middle Tualatin Watershed hydrologic units. The Bronson Creek catchment boundary was created by combining Clean Water Service's digital drainage polygons for Bronson and Bannister Creeks. The resulting $7^{\text {th }}$ field watershed is composed of 37 subcatchments whose extents were delineated by Clean Water Services (Figure 3). 


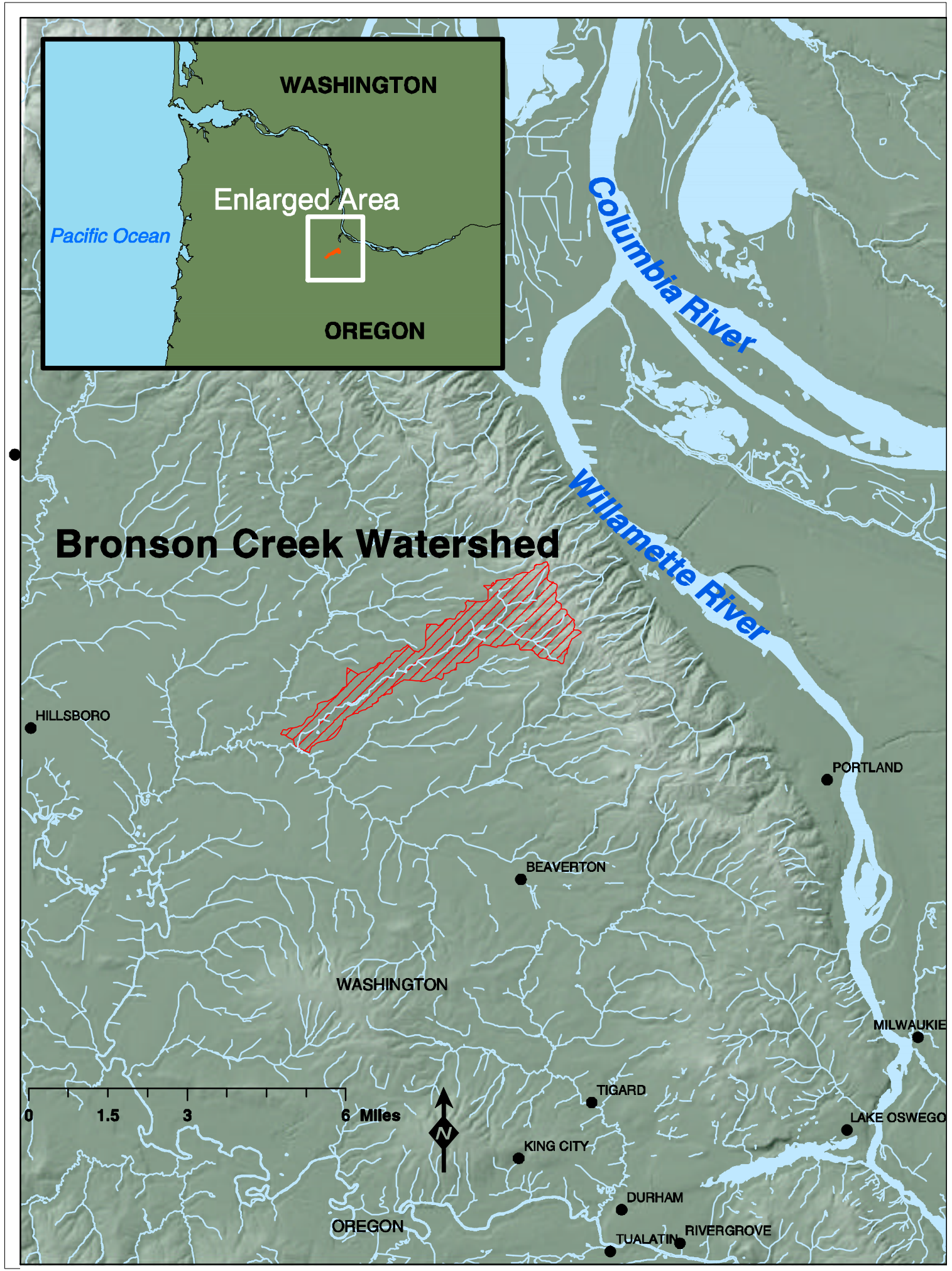

Figure 1 Overview map of Bronson Creek Watershed 


\section{Tualatin River Hydrologic Units}

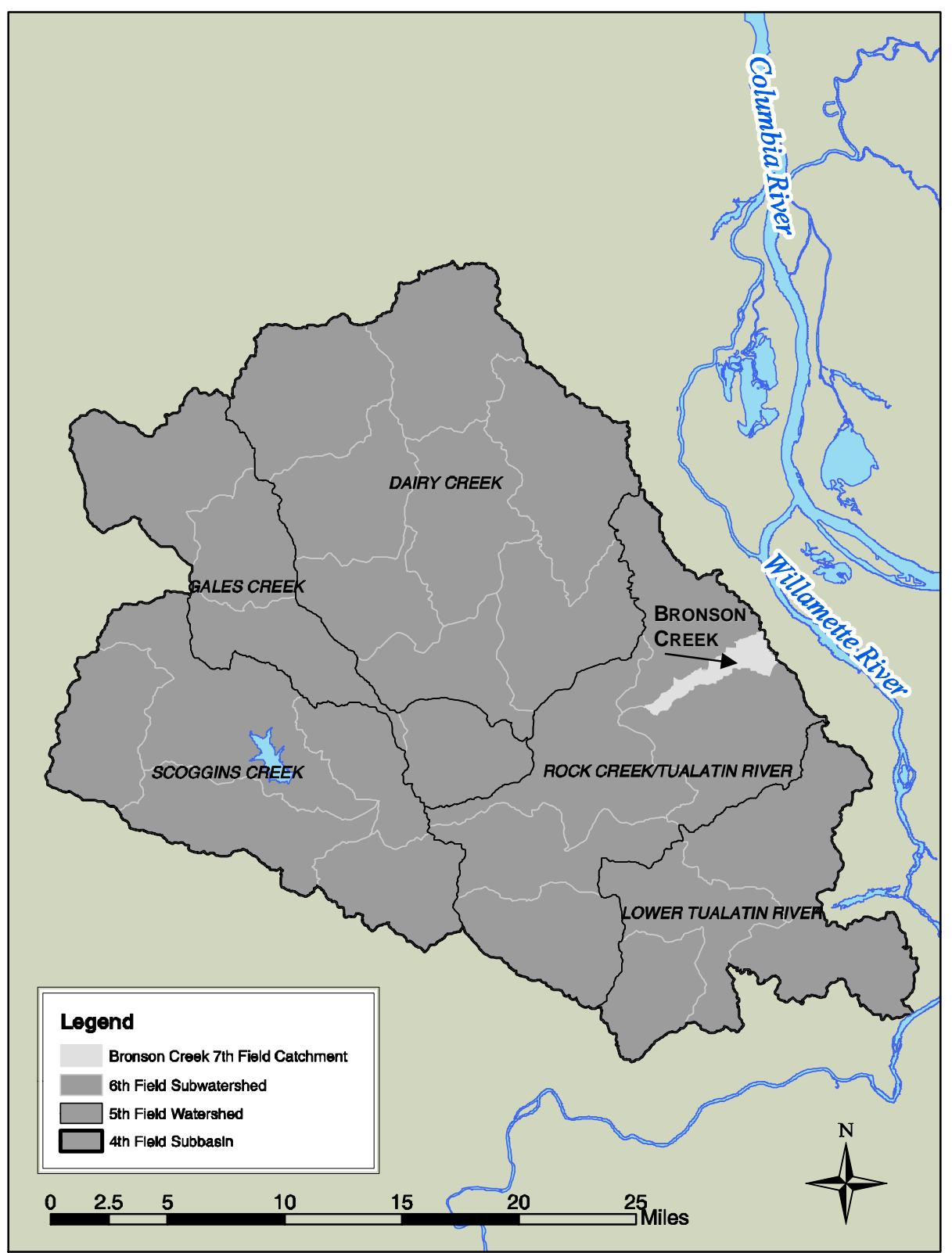

Figure 2 Middle Tualatin Watershed hydrologic units 
Table 2 Bronson Creek Watershed (Catchment) HUC address (REO 2003b)

\begin{tabular}{|c|c|c|c|}
\hline HUC & Class & Name & Code \\
\hline 1 & Region & Pacific Northwest & 17 \\
\hline 2 & Subregion & Willamette & 09 \\
\hline 3 & Basin & Willamette & 00 \\
\hline 4 & Subbasin & Tualatin & 04 \\
\hline 5 & Watershed & Rock Creek \Tualatin & 03 \\
\hline 6 & Subwatershed & Beaverton Creek & undefined \\
\hline $\mathbf{7}$ & Catchment & Bronson Creek & undefined \\
\hline 8 & Subcatchment & undefined & \\
\hline
\end{tabular}




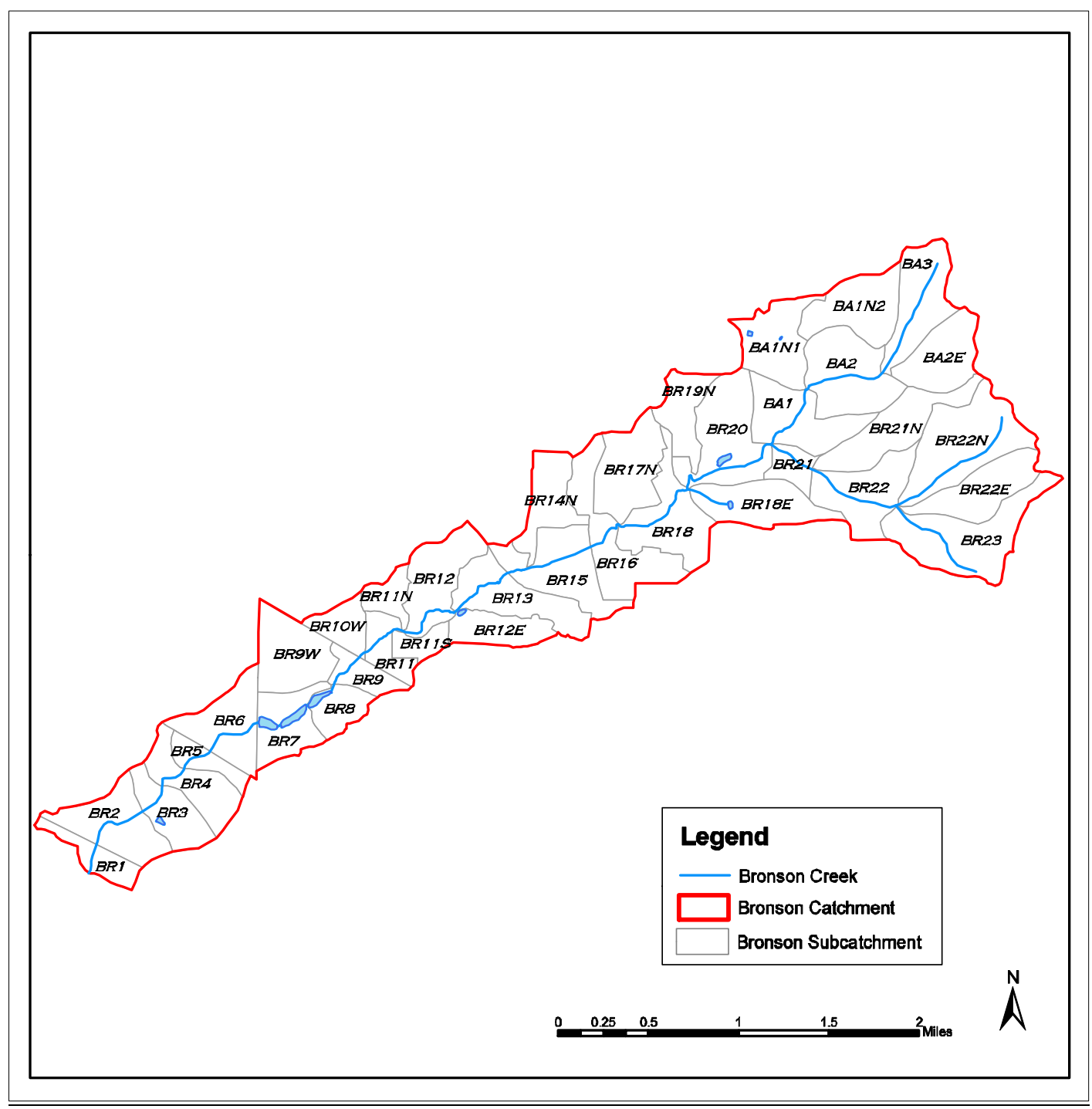

\section{Figure 3 Bronson Creek subcatchments}

The Watershed Vulnerability Handbook recommends performing watershed or impervious surface analysis at the subwatershed level (Zielinski 2002). The rationale is influenced by the size of the subwatershed. It is small enough that it is typically not part of several jurisdictions with varying storm water management plans, it won't be influenced by confounding pollutant sources, the influence of impervious surfaces on hydrology and water quality will be perceptible, and its size will allow a timely analysis 
(Zielinski 2002). Table 3 highlights the optimal management unit for impervious area analysis as described by The Watershed Vulnerability Handbook.

Table 3 Description of the various watershed management units (from Zielinski 2002)

\begin{tabular}{|l|l|l|l|}
\hline $\begin{array}{l}\text { Watershed } \\
\text { Management Unit }\end{array}$ & $\begin{array}{l}\text { Typical Area } \\
\text { (square miles) }\end{array}$ & $\begin{array}{l}\text { Influence of } \\
\text { Impervious Cover }\end{array}$ & $\begin{array}{l}\text { Sample Management } \\
\text { Measures }\end{array}$ \\
\hline Catchment & 0.05 to 0.5 & very strong & $\begin{array}{l}\text { stormwater management } \\
\text { and site design }\end{array}$ \\
\hline Subwatershed & 0.5 to 30 & strong & $\begin{array}{l}\text { stream classification and } \\
\text { management }\end{array}$ \\
\hline Watershed & 30 to 100 & moderate & watershed-based zoning \\
\hline Sub-basin & 100 to 1,000 & weak & basin planning \\
\hline Basin & 1,000 to 10,000 & very weak & basin planning \\
\hline
\end{tabular}

Even though the Bronson Creek drainage area is classified as a catchment, it meets the assumptions set by the Watershed Vulnerability Handbook. It's size, 3195 acres (5.0 $\mathrm{mi}^{2}$ ) falls within the subwatershed category suggesting that impervious cover should have a dominate influence on the area.

\section{Hydrology}

According to the Bureau of Land Management (BLM), all streams within the Rock Creek / Middle Tualatin watershed, including Bronson Creek, experience seasonal variation in flow that are typified by peaks in the winter and lows in the summer (Hawksworth 2001). Figure 4 is a hydrograph of Bronson Creek at West Union which depicts this season variation. 


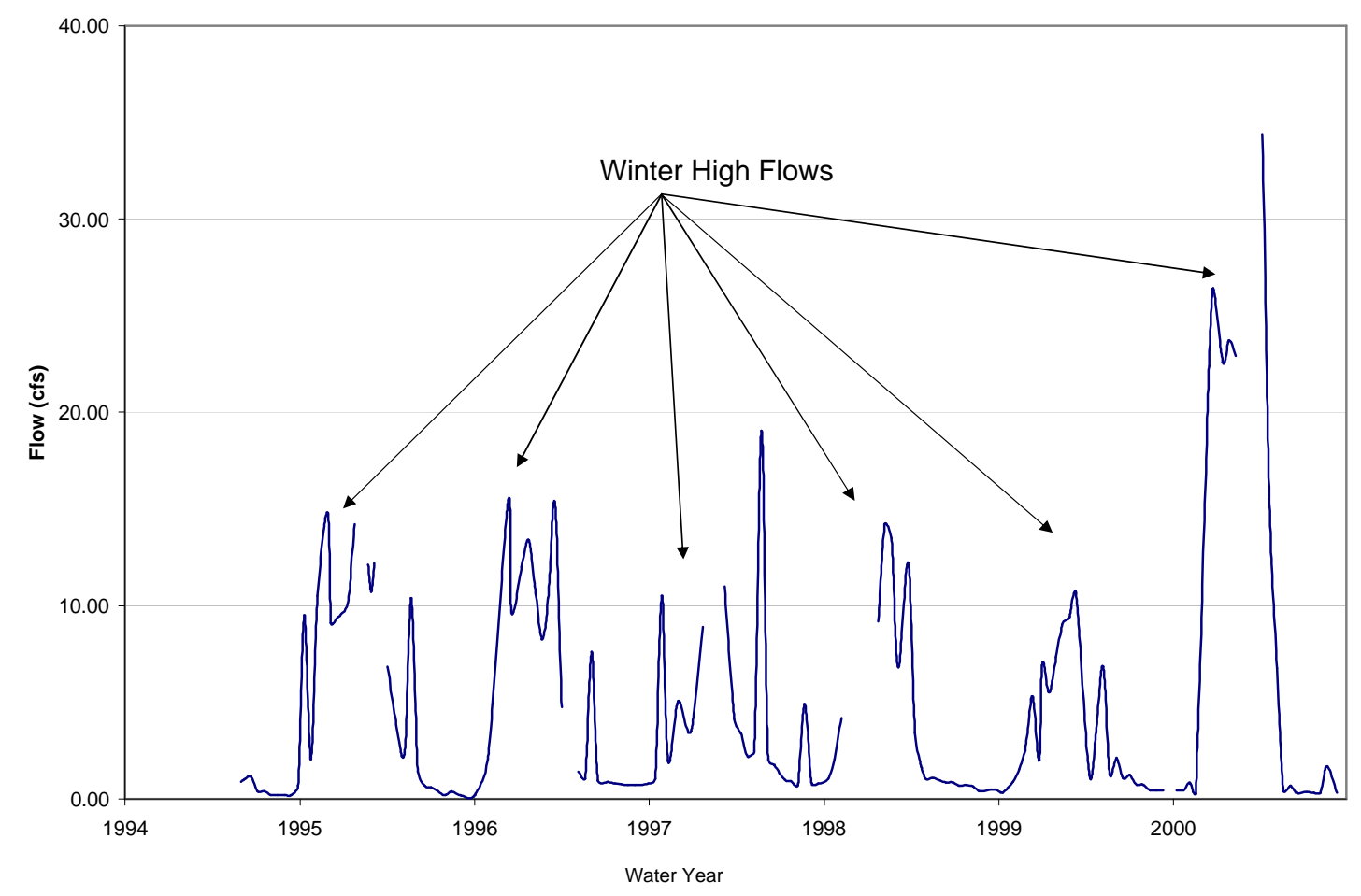

Figure 4 Bronson Creek hydrograph at West Union

\section{Land Use}

The headwaters of Bronson Creek lie just west of Skyline drive in the West Hills of Portland. This area is typified by rural land use with minor encroachment of suburban housing development, though much of the undeveloped land in the headwaters has been zoned for single family residential development. From its confluence with Bannister Creek (River Mile 5.5) downstream to the crossing at Highway 26 (River Mile 2.3), the majority of the watershed has been developed with single family housing with suburban style neighborhoods. The remainder of the watershed from the Highway 26 crossing to the convergence of Bronson and Rock Creeks, is mixed use and commercially developed. The Tanasbourne Village and Tanasbourne Town Center are located in this area. There 
are also a few multifamily apartment complexes scattered at the lower end of the basin (Metro 2001). Table 4 for provides a breakdown of land use classification within Bronson Creek watershed for 2001 and Figure 5 is a map showing these land use categories.

\section{Table 42001 Bronson Creek Watershed land use statistics}

(Metro 2001)

\begin{tabular}{|l|c|}
\hline General Zoning Classification within Bronson Creek Watershed & Percent \\
\hline Commercial & $5.9 \%$ \\
\hline Industrial & $7.3 \%$ \\
\hline Multi-family residential & $5.5 \%$ \\
\hline Mixed use & $8.4 \%$ \\
\hline Public/open space & $1.3 \%$ \\
\hline Rural & $24.0 \%$ \\
\hline Single family residential & $47.6 \%$ \\
\hline
\end{tabular}




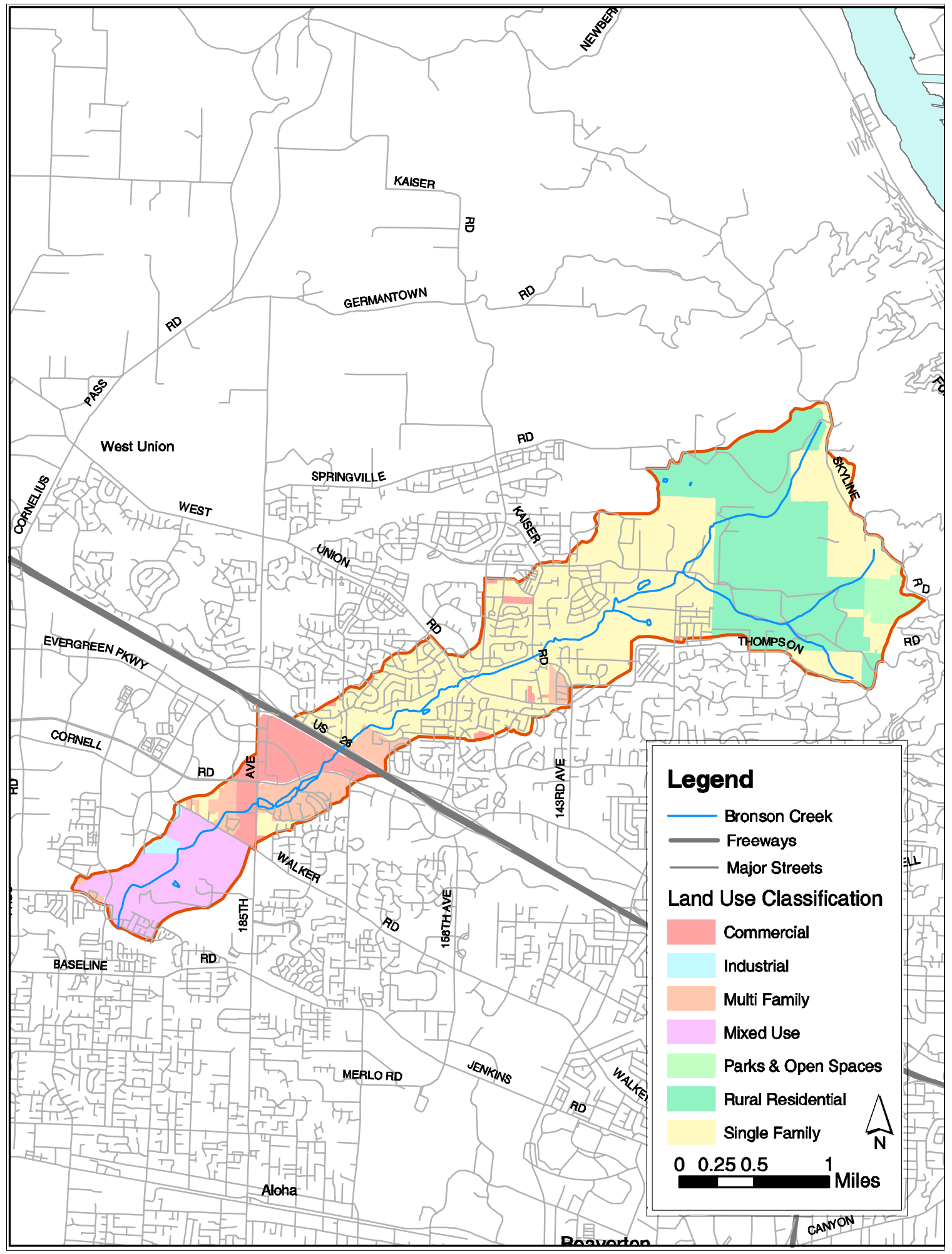

Figure 52001 Bronson Creek Watershed land use (Metro RLIS 2001) 


\section{Management}

Agency

Clean Water Services (CWS), formally the Unified Sewerage Agency (USA), is a public utility which is responsible for the management of water resources within the Tualatin Watershed. Waste and surface water management are two of Clean Water Services primary functions, though CWS plays an important and active roll in water quality and watershed health protection (CWS 2003). CWS, which is a Designated Management Agency (DMA), per Clean Water Act specifications, is also charged with implementing a plan to address water quality within its service area as defined by the Oregon Department of Environmental Quality (DEQ) (ODEQ 2001).

\section{Total Maximum Daily Loads}

Currently, seven water quality parameters within Bronson Creek are listed for Total Maximum Daily Loads (TMDLs) as defined by section 303(d) of the Clean Water Act. This section mandates that states are responsible for cataloging all impaired and threatened waterbodies within their boundaries. The CWA requires states to establish TMDLs for waterbodies that violate established water quality standards (ODEQ 2001). In Oregon, the Department of Environmental Quality (DEQ) is responsible for creating TMDLs for waterbodies on the 303(d) list.

A TMDL is a plan that is created to make certain that water quality is returned to a nonthreatening level. The Oregon Department of Environmental Quality defines a TMDL as, 
"the total amount of a pollutant (from all sources) that can enter a specific waterbody without violating the water quality standards." (ODEQ 2001)

In 1988, the first waterbodies within the Tualatin watershed were put on the 303(d) list. TMDLs were prepared for dissolved oxygen (DO) via ammonina $\left(\mathrm{NH}_{3}\right)$ and phosphorus that same year. As a result of the listing and implementation of TMDLs, ammonia and total phosphorus levels within the Tualatin watershed have improved (ODEQ 2001). Waste water treatment plants (WWTP) were upgraded between 1988 and 1994 (CWS 2001a). These upgrades have been responsible for dramatic decreases in ammonia along the lower reaches of the Tualatin (ODEQ 2001). At the time of the January 2001 CWS report, the Tualatin Basin was meeting the ammonia TMLD requirements (CWS 2001a). Total phosphorous levels have also improved as a result of upgrades to WWTPs and the implementation of best management practices (BMP) that have reduced nonpoint inputs of phosphorous. The reduction in phosphorous since the implementation of the 1988 TMDL has lead to some success in controlling algal blooms, but the critical levels that were set by the TMDL are still being exceeded throughout the Tualatin watershed (ODEQ 2001).

Oregon established new water quality criteria in 1996 in an effort to improve the health of its streams and rivers. Measures were put in place to regulate water temperature, phosphorous, nitrate, bacteria, and pH (USGS 1997). The Oregon 303(d) list was appended again in 1998 for waterbodies within the Tualatin watershed. Temperature, bacteria, $\mathrm{DO}, \mathrm{pH}$, biological criteria, arsenic, iron, and manganese were added to the list 
of impairments to water quality. In 2001, the TMDLs for ammonia and phosphorous were revised and TMDLs were created for bacteria, temperature, and volatile solids (ODEQ 2001). Table 5 highlights the water quality parameters within the Tualatin basin that have been put on the State of Oregon's 303(d) list of threatened water bodies.

Table 5 Active TMDLs within the Tualatin Watershed (from ODEQ 2001)

\begin{tabular}{lccc} 
Parameter & 303(d) listing & TMDL & Within Bronson Creek \\
\hline Temperature & 1998 & Yes & Yes \\
Bacteria & 1998 & Yes & Yes \\
DO & 1998 & Yes & Yes \\
Settleable Volatile Solids & 2001 & No & n/a \\
Ammonia & 1988 & Yes & Yes \\
Chlorophyll a & 1998 & Yes & Yes \\
pH & 1998 & Yes & No \\
Phosphorus & 1988 & Yes & Yes \\
Biological criteria & 1998 & No & n/a \\
Arsenic & 1998 & No & n/a \\
Iron & 1998 & No & n/a \\
Manganese & 1998 & No &
\end{tabular}

\section{Data}

As part of the Bronson Watershed Project, an ongoing study of watershed urbanization, CWS has been sampling approximately 39 water quality parameters at 8 sampling stations along Bronson Creek twice a month since 1994 (CWS 2001b). Of the 39 water quality variables, eight were chosen by CWS to be included in this analysis. These variables are considered problematic in Bronson Creek or other parts of the Tualatin watershed and have either been assigned a TMDL are in jeopardy of exceeding a critical level that has been assigned to the parameter. Table 6 lists the water quality variables that were included in the analysis with TMDL and critical level information. 


\section{Table 6 Project variables, critical levels and minimum detection limits}

\begin{tabular}{|c|c|c|c|c|}
\hline WQ Variable & Critical Level & MDL & $\begin{array}{c}\text { Critical Level } \\
\text { Description }\end{array}$ & $\begin{array}{l}\text { 303(d) } \\
\text { Listing }\end{array}$ \\
\hline Temperature & $17.8^{\circ} \mathrm{C}$ & $?$ & CurrentTMDL & 1998 \\
\hline Ortho- & & & & \\
\hline Phosphorous & $0.13 \mathrm{mg} / \mathrm{L}$ & $0.01 \mathrm{mg} / \mathrm{L}$ & TMDL & 1988 \\
\hline TSS & $?$ & $?$ & & \\
\hline Fecal & $<10 \%$ of samples with $>400$ & & & \\
\hline Coliform & organisms/ $100 \mathrm{~mL}$ & $\begin{array}{c}4 \\
0.02,0.025,0.0\end{array}$ & pre-1995 value & \\
\hline $\begin{array}{l}\text { Ammonia } \\
\text { Total }\end{array}$ & $0.1 \mathrm{mg} / \mathrm{L}$ & 1 & DO & 1988 \\
\hline Phosphorous & $0.13 \mathrm{mg} / \mathrm{L}$ & $?$ & TMDL & 1988 \\
\hline E. Coli & 406 organisms $/ 100 \mathrm{~mL}$ & $1,4,17$ & TMDL & \\
\hline Nitrogen & $10 \mathrm{mg} / \mathrm{L}$ & $0.01,0.03,0.01$ & & 1998 \\
\hline
\end{tabular}

The period of record for the dataset that was delivered to PSU for analysis was from January 1994 to March 2002. Year 2002 data were excluded from the analysis because the full year of data was not available. After initial analysis fecal coliform was dropped from the project due to a lack of data. Sampling for fecal coliform ended in April of 1996.

CWS sampling sites were longitudinally dispersed along Bronson Creek with sites located in the head waters of the watershed (RM 6.0) downstream to the bottom of the watershed near the confluence of Bronson and Rock Creeks (RM 01). Figure 6 shows the location of the sampling sites along Bronson Creek. 


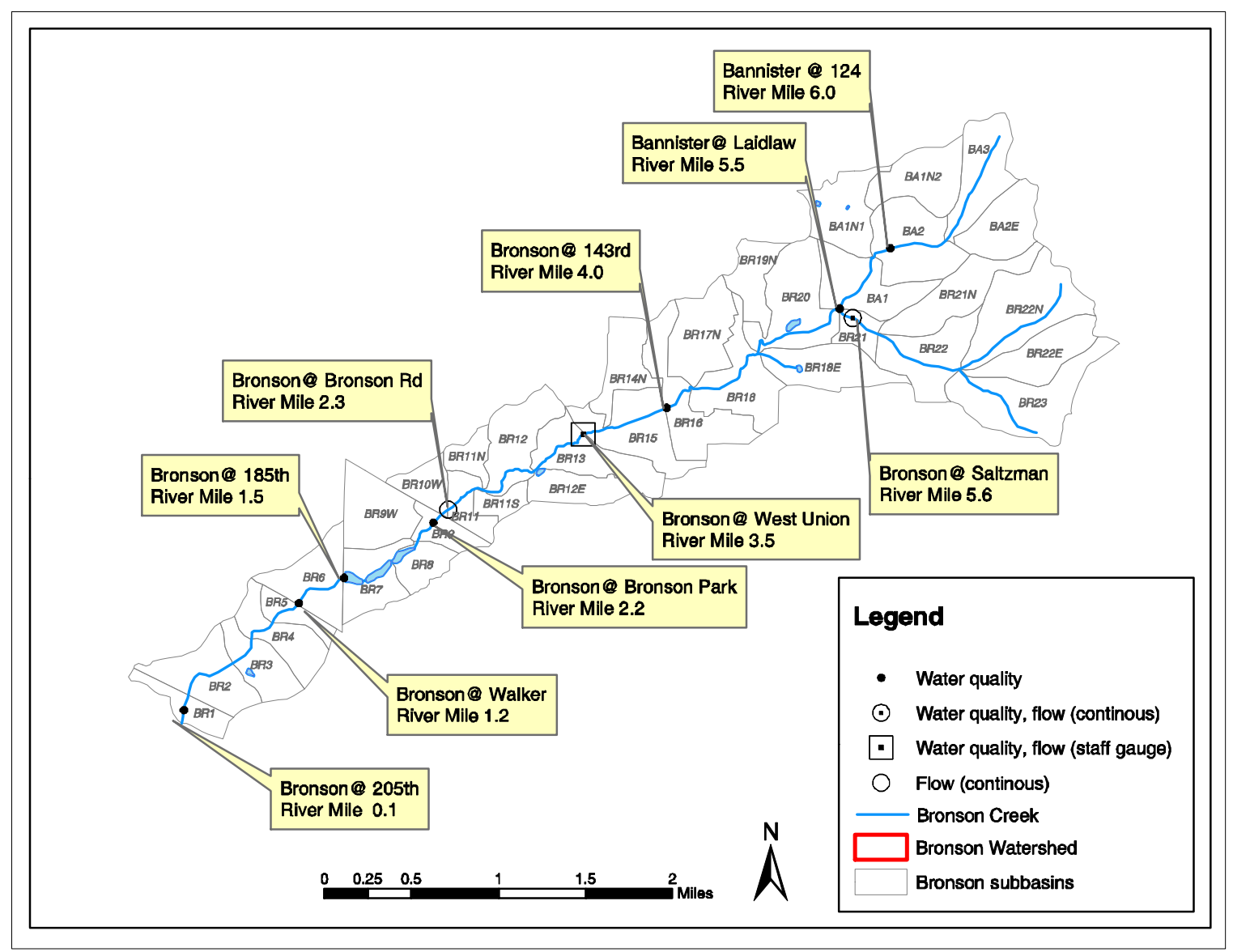

Figure 6 Map of Bronson Creek sampling sites

\section{Water Quality}

Water quality within Bronson Creek has been a concern since the first TMDLs were put in place in 1988. Bronson Creek has been identified as having some of the highest phosphorous levels within the Middle Tualatin watershed. In 2001, the BLM reported that the highest median (May - Oct) phosphorous levels and the highest maximum phosphorous levels recorded within the Middle Tualatin watershed were in Bronson Creek (BLM 2001). 
The $17.8^{\circ} \mathrm{C}$ temperature standard was created to provide habitat protection for cold water aquatic species. In 1997, Bronson Creek had the largest number of temperature readings in the Middle Tualatin above the $17.8^{\circ} \mathrm{C}$ critical level (BLM 2001). 


\section{Impervious Area Analysis}

\section{A. Calculating Total Impervious Area}

There are several methods available to measure the amount of imperviousness within a watershed. The technique used to measure impervious area is usually depends on the scale of the analysis. For a small site study, actual on the ground measurements can be used. Because physical measurements are taken, this method is time consuming, but produces the most accurate results of any of the available techniques. The large amount of time required to measure impervious features on site typically limits this procedure to being used on the smallest of projects. Other methods are utilized on larger scale projects.

For community or regional scale analysis, digitizing impervious surfaces from aerial photography is generally considered the best approach. This method also produces the best compromise between time, accuracy, and cost (Arnold and Gibbons 1996). For the largest of projects, remote sensing analysis is generally the best choice for calculating impervious area statistics. This procedure involves interpreting digital satellite imagery for a study area (Sleavin et al. 2000 ).

A final technique to quantify imperviousness involves indirectly calculating impervious area through a surrogate measure. Impervious surface coefficients that relate impervious percentages to specific land use classifications are used (NRCS 1996). Land use or 
zoning data from city or regional data bases can therefore be converted to impervious surface area (Zielinski 2002).

Total impervious area (TIA) for the Bronson Creek watershed was calculated using direct digitizing techniques. ESRI ArcGIS (version 8.1) geographic information system (GIS) was used to digitize impervious feature polygons from aerial photography. The total area of these polygons and the areas of Bronson Creek and its subcatchments were used to produce the TIA percentages for the watershed. TIA values were calculated for the $378^{\text {th }}$ field subcatchments of Bronson Creek for years 1994 -2001 and aggregated to determine TIA values for the entire catchment during the same period.

\section{Methods used to calculate TIA}

All impervious features were created and stored in the personal geodatabase format. This is a relatively new data storage format that has many benefits over the older ESRI shapefile and coverage file formats. Several of these benefits were the primary drivers in choosing the geodatabase for the project. The data structure of the geodatabase allowed multiple users on personal workstations to work on the project and import individual feature classes when necessary. Projection parameters for multiple files were of no concern since the parameters were set for the entire personal geodatabase when it was initially created. The geodatabase format also allowed for the creation and storage of true curves. The nature of this digitizing project required that many curved impervious features, such as roads and parking lots, to be digitized. The true curve feature allowed 
polygons to be created in a timely manner. Time savings results from the input of fewer vertices (or mouse clicks) by the operator.

The projection parameters for this project were Oregon State Plane North, North American Datum (NAD 83/91), with units in international feet. This format is a standard projection for the area and also corresponds to the digital aerial photography that was used to identify and create the impervious features.

\section{$\underline{\text { Data and data sources }}$}

The impervious features were digitized from aerial photography, either digital or paper, for years 1994 to 2001. The data were compiled from a variety of sources from the Portland metro area. The format, source, and resolution of the photography are given in Table 7.

Table $7 \quad$ Format, source and resolution of aerial photography

\begin{tabular}{|c|c|c|c|}
\hline YEAR & FORMAT & SOURCE & RESOLUTION \\
\hline 2001 & Digital & Metro & $1.0 \mathrm{ft}$ \\
\hline 2000 & Digital & Clean Water Services & $2.0 \mathrm{ft}$ \\
\hline 1999 & Digital & Clean Water Services & $2.0 \mathrm{ft}$ \\
\hline 1998 & Digital & Spenser B. Gross & $2.0 \mathrm{ft}$ \\
\hline 1997 & Digital & Metro & $4.0 \mathrm{ft}$ \\
\hline 1996 & Digital & Spenser B. Gross & $2.0 \mathrm{ft}$ \\
\hline 1995 & Mylar & Metro & $\mathrm{n} / \mathrm{a}$ \\
\hline 1994 & Digital & Spenser B. Gross & $1.3 \mathrm{ft}$ \\
\hline
\end{tabular}

Year 2000 was used as the reference year for this project, since it was the first year that was made available to the project team and was the most recent photography owned by Clean Water Services at the inception of the project. The reference year photography 
was the only year digitized in its entirety. Rather than digitize the watershed 7 times, once for each year, impervious features were added to and subtracted from the reference year. This method served 3 functions. The first was to reduce the amount of the time spent digitizing. A building that was built prior to 1994 was only digitized once and copied 6 times into the geodatabases for each subsequent year, instead of being digitized 7 separate times. This procedure also maintained consistency of the project because each impervious feature was only digitized once. Therefore, only one area was calculated for each surface, which reduced error when yearly TIA values were compared. The quality and resolution of the aerial photography as well as user interpretation would cause the area of a feature to vary from year to year. The accuracy of the results also increased with this methodology because the digitized surfaces for each year were compared to the years before and after. This redundancy reduced the chances of an impervious feature being missed because of image quality or user error.

All surfaces were heads up digitized from the digital aerial photography at an on screen scale of 1:1000, except for 1995 where digital photography was not available.

Impervious surfaces were grouped into 6 categories; buildings, roads, sidewalks, driveways, parking lots, and miscellaneous. Personal geodatabases were created for each year of the study to ease data management and work loads issues. 6 feature classes representing the impervious classifications were built within each of the yearly geodatabases. Each impervious surface that was visible at the project scale $(1: 1000)$ was 
digitized to its designated feature class within the geodatabase for the year of the underlying photography.

The arterials layer of Metro's Regional Land Information System (RLIS) dataset was used to aid in the interpretation of the roads from the aerial photography. In some cases, there were difficulties distinguishing paved roads from unpaved gravel roads in the upper reaches of the watershed. The RLIS data was used to rectify any of these discrepancies.

\section{Planimetric Data Conversion}

Digital planimetric data were incorporated into the project for sections of Bronson Creek watershed that were within Beaverton and Hillsboro city limits. This was a time saving mechanism due to the tedious and time intensive nature of digitizing. Planimetric data accounted for approximately $20 \%$ of the total project area. These datasets were delivered to the project team by the respective city governments in AutoCAD DWG file format. The files were preprocessed in AutoCAD to remove unnecessary layers and to close impervious polygons before importing into the personal geodatabase format.

The planimetric data were integrated into the 2000 reference geodatabase at the start of the project. Impervious polygons were not digitized in the areas where there was planimetric data coverage. The imported planimetric polygons were compared to the 2000 aerial photography to check for inconsistencies. Impervious features were missing in some areas because the plannimetric datasets were created prior to 2000 . The 
completed 2000 dataset was used to create 1999 and 2001 impervious data after all discrepancies were resolved.

A flow diagram of the process (Figure 7) illustrates the data creation process.

\section{Mylar Photos (1995)}

The process used to create the 1995 impervious feature data set varied from the process used for the other years in the study. Digital aerial photography was not available for the project study area for 1995 so copies of mylar plots were used to instead. These copies were purchased from Metro, Portland Oregon. Eight sheets at the scale of 1" to 400' were needed to cover the Bronson Creek watershed. The impervious features for 1996 were plotted at the same scale as the aerial photography and then overlaid on a light table to identify impervious features that were constructed over the year. The plots of the 1996 impervious surfaces were marked up to identify features that did not exist in 1995 . The marked up plots were then used to aid in the on screen removal digital polygons in the 1995 personal geodatabase. 
URBANIZATION AND ITS RELATIONSHIP TO WATER QUALITY WITHIN THE BRONSON CREEK WATERSHED

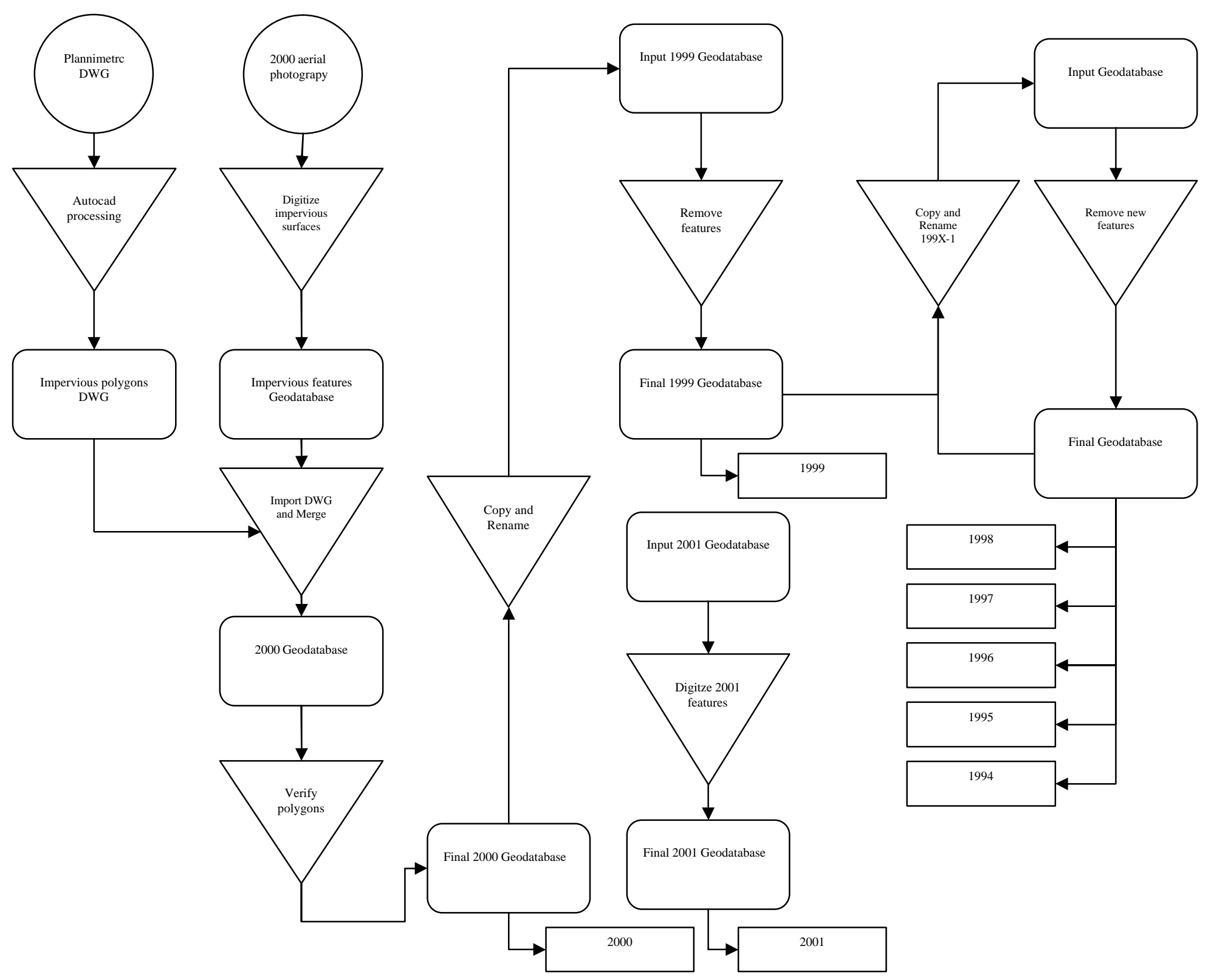

Figure $7 \quad$ Flow diagram of digitizing process 


\section{B. Results of Total Impervious Area Analysis}

Total impervious area and percent impervious were calculated for the Bronson Creek watershed and 37 subbasins for each year. The annual values of impervious area are presented in Table 8. The total area of the Bronson Creek watershed is 3194.8 acres. Bronson Creek's imperviousness increased at an average rate of $1.2 \%\left(\mathrm{R}^{2}=0.972\right)$ per year from 1994 to 2001 as shown in Figure 8.

Table 8 Total impervious area from 1994 through 2001 in the Bronson Creek Watershed

\begin{tabular}{|c|c|c|}
\hline Year & TIA (acres) & TIA\% \\
\hline 2001 & 714.8 & $22.4 \%$ \\
\hline 2000 & 701.7 & $22.0 \%$ \\
\hline 1999 & 685.9 & $21.5 \%$ \\
\hline 1998 & 643.9 & $20.2 \%$ \\
\hline 1997 & 601.5 & $18.8 \%$ \\
\hline 1996 & 548.6 & $17.2 \%$ \\
\hline 1995 & 504.1 & $15.8 \%$ \\
\hline 1994 & 464.7 & $14.5 \%$ \\
\hline
\end{tabular}


Bronson Creek Total Impervious Area \%

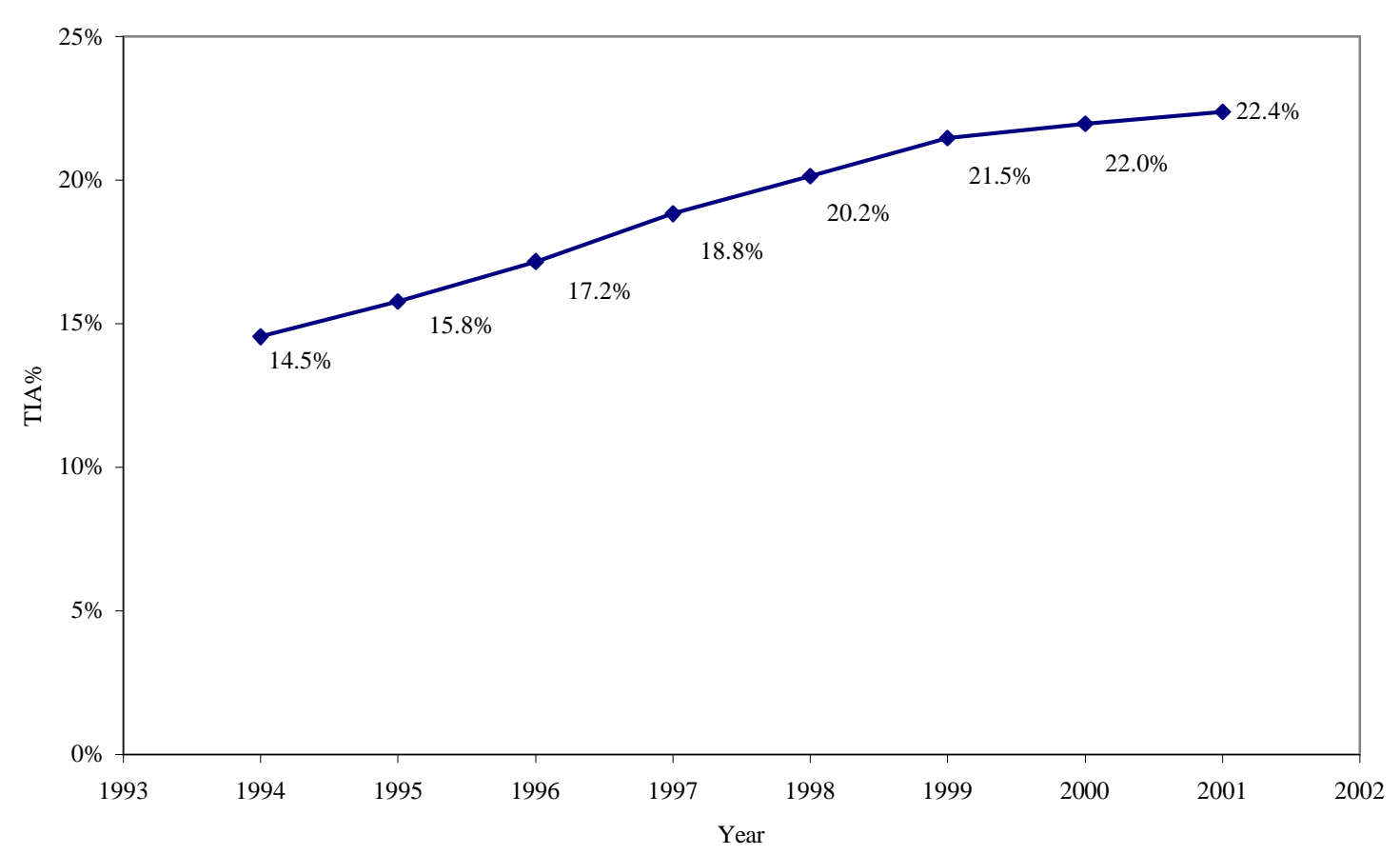

Figure 8 Increase in impervious area, as a percentage of the total basin area, for the Bronson Creek watershed.

$\underline{\text { Subbasin changes in TIA }}$

Bronson Creek watershed and subbasin boundary files provided by Clean Water Services were used to delineate the watershed and its subbasins. The Clean Water Services watersheds data breaks Bannister Creek (BA) out into a separate watershed, but the 2 watersheds of Bronson and Bannister Creeks were merged for the purposes of this analysis. In total, 37 Bronson Creek and Bannister Creek subbasins make up the Bronson Creek watershed that was analyzed for this project. The majority of the urbanization took place within 5 of the 37 subbasins during the 7 year study period. TIA increased more 
than 20 percentage points within these 5 subbasins while the remainder of the subbasins experienced only a modest amount of development. A cluster of 4 of the 7 urbanizing subbasins were adjacent to each other, located near Kaiser and West Union roads. The increased TIA values in this area resulted primarily from the construction of single family homes in a suburban setting. A summary of the change in TIA for each of the subbasins over the 7 year period is presented in Figure 9 and Table 9. Subbasins experiencing growth of more than 20 percentage points are highlighted in Table 9. 


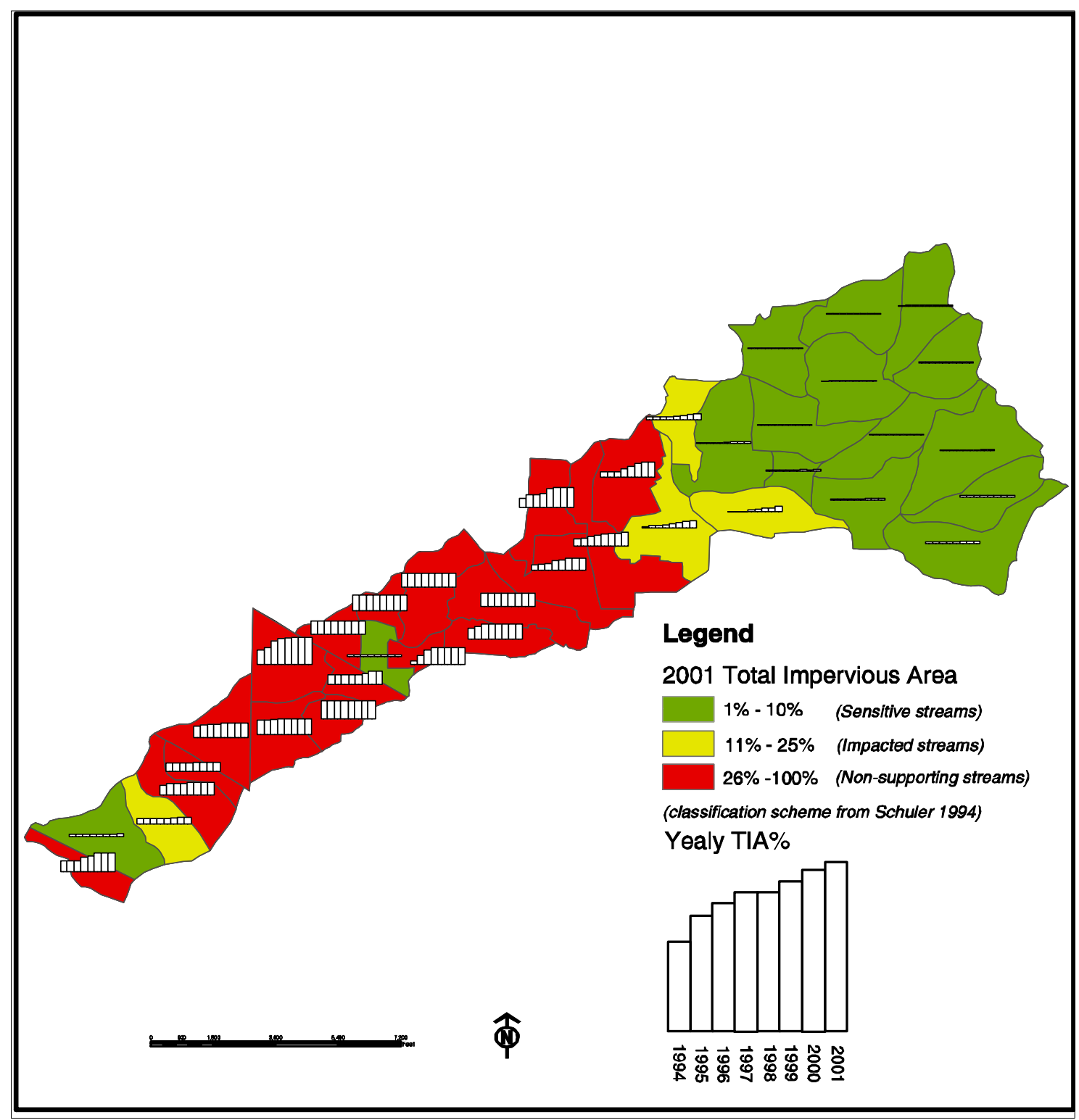

Figure 92001 Bronson TIA\% and TIA change from 1994-2001 
Table $9 \quad$ TIA\% for Bronson Subbasins 1994 - 2001

\begin{tabular}{|c|c|c|c|c|c|c|c|c|c|}
\hline SUBID & Acres & 1994 & 1995 & 1996 & 1997 & 1998 & 1999 & 2000 & 2001 \\
\hline BR1 & 44.1 & $33.4 \%$ & $33.4 \%$ & $33.4 \%$ & $40.8 \%$ & $45.3 \%$ & $53.2 \%$ & $53.2 \%$ & $53.2 \%$ \\
\hline BR2 & 102.4 & $5.8 \%$ & $5.8 \%$ & $5.8 \%$ & $6.4 \%$ & $6.8 \%$ & $6.8 \%$ & $6.8 \%$ & $7.8 \%$ \\
\hline BR3 & 70.1 & $17.1 \%$ & $17.1 \%$ & $17.1 \%$ & $17.4 \%$ & $17.4 \%$ & $17.6 \%$ & $18.9 \%$ & $20.2 \%$ \\
\hline BR4 & 78.0 & $27.5 \%$ & $34.1 \%$ & $34.1 \%$ & $34.2 \%$ & $35.8 \%$ & $35.8 \%$ & $35.8 \%$ & $35.8 \%$ \\
\hline BR5 & 34.8 & $25.3 \%$ & $25.3 \%$ & $25.3 \%$ & $25.3 \%$ & $26.8 \%$ & $26.8 \%$ & $26.8 \%$ & $26.8 \%$ \\
\hline BR6 & 96.0 & $32.6 \%$ & $35.3 \%$ & $38.1 \%$ & $38.6 \%$ & $41.0 \%$ & $41.1 \%$ & $41.1 \%$ & $41.1 \%$ \\
\hline BR7 & 78.3 & $41.7 \%$ & $42.5 \%$ & $43.9 \%$ & $44.5 \%$ & $45.7 \%$ & $45.7 \%$ & $45.7 \%$ & $45.7 \%$ \\
\hline BR8 & 45.9 & $52.5 \%$ & $52.5 \%$ & $52.5 \%$ & $52.5 \%$ & $52.5 \%$ & $52.5 \%$ & $52.5 \%$ & $52.5 \%$ \\
\hline BR9 & 39.5 & $27.6 \%$ & $27.6 \%$ & $27.8 \%$ & $28.0 \%$ & $28.0 \%$ & $31.9 \%$ & $38.5 \%$ & $38.5 \%$ \\
\hline BR9W & 99.8 & $42.5 \%$ & $47.8 \%$ & $68.1 \%$ & $74.4 \%$ & $76.2 \%$ & $78.3 \%$ & $78.3 \%$ & $78.3 \%$ \\
\hline BR10W & 42.7 & $37.7 \%$ & $37.7 \%$ & $37.7 \%$ & $37.7 \%$ & $37.7 \%$ & $37.8 \%$ & $38.1 \%$ & $38.1 \%$ \\
\hline BR11 & 42.1 & $5.5 \%$ & $5.5 \%$ & $5.6 \%$ & $5.6 \%$ & $5.6 \%$ & $5.6 \%$ & $5.4 \%$ & $5.4 \%$ \\
\hline BR11N & 33.7 & $45.4 \%$ & $45.4 \%$ & $45.4 \%$ & $45.4 \%$ & $45.4 \%$ & $45.4 \%$ & $45.3 \%$ & $45.3 \%$ \\
\hline BR11S & 28.2 & $9.4 \%$ & $26.7 \%$ & $41.9 \%$ & $49.3 \%$ & $49.3 \%$ & $49.3 \%$ & $49.2 \%$ & $49.2 \%$ \\
\hline BR12 & 99.7 & $38.6 \%$ & $38.7 \%$ & $38.8 \%$ & $38.8 \%$ & $38.8 \%$ & $38.8 \%$ & $38.8 \%$ & $38.9 \%$ \\
\hline BR12E & 61.2 & $31.6 \%$ & $35.7 \%$ & $43.8 \%$ & $44.9 \%$ & $44.9 \%$ & $44.9 \%$ & $45.1 \%$ & $45.1 \%$ \\
\hline BR13 & 104.1 & $39.0 \%$ & $39.4 \%$ & $39.5 \%$ & $39.5 \%$ & $39.5 \%$ & $39.6 \%$ & $39.7 \%$ & $39.7 \%$ \\
\hline BR14N & 72.9 & $24.7 \%$ & $37.7 \%$ & $37.8 \%$ & $41.3 \%$ & $53.8 \%$ & $58.7 \%$ & $59.3 \%$ & $59.3 \%$ \\
\hline BR15 & 118.3 & $16.5 \%$ & $17.9 \%$ & $19.9 \%$ & $28.2 \%$ & $31.0 \%$ & $34.8 \%$ & $36.0 \%$ & $36.3 \%$ \\
\hline BR16 & 122.8 & $19.5 \%$ & $22.6 \%$ & $28.0 \%$ & $31.0 \%$ & $33.6 \%$ & $36.8 \%$ & $38.5 \%$ & $39.8 \%$ \\
\hline BR17N & 106.1 & $12.8 \%$ & $12.8 \%$ & $12.8 \%$ & $24.4 \%$ & $31.3 \%$ & $39.2 \%$ & $40.7 \%$ & $41.1 \%$ \\
\hline BR18 & 112.8 & $3.5 \%$ & $4.9 \%$ & $6.1 \%$ & $9.3 \%$ & $13.1 \%$ & $17.0 \%$ & $19.1 \%$ & $20.9 \%$ \\
\hline BR18E & 97.3 & $2.3 \%$ & $2.3 \%$ & $2.3 \%$ & $5.6 \%$ & $7.9 \%$ & $10.9 \%$ & $11.5 \%$ & $16.4 \%$ \\
\hline BR19N & 61.5 & $6.7 \%$ & $6.7 \%$ & $6.8 \%$ & $7.0 \%$ & $8.0 \%$ & $13.1 \%$ & $16.0 \%$ & $17.9 \%$ \\
\hline BR20 & 136.0 & $3.2 \%$ & $3.2 \%$ & $3.4 \%$ & $3.4 \%$ & $5.5 \%$ & $7.1 \%$ & $7.8 \%$ & $7.9 \%$ \\
\hline BR21 & 32.1 & $5.3 \%$ & $5.3 \%$ & $5.3 \%$ & $6.2 \%$ & $6.2 \%$ & $6.5 \%$ & $6.4 \%$ & $7.1 \%$ \\
\hline BR21N & 105.4 & $1.8 \%$ & $2.0 \%$ & $2.0 \%$ & $2.7 \%$ & $2.7 \%$ & $2.7 \%$ & $2.7 \%$ & $3.0 \%$ \\
\hline BR22 & 107.3 & $3.4 \%$ & $3.5 \%$ & $3.5 \%$ & $3.5 \%$ & $3.5 \%$ & $3.6 \%$ & $3.7 \%$ & $3.7 \%$ \\
\hline BR22E & $\begin{array}{l}90.8 \\
\end{array}$ & $4.8 \%$ & $5.1 \%$ & $5.1 \%$ & $5.1 \%$ & $5.1 \%$ & $5.1 \%$ & $5.0 \%$ & $5.0 \%$ \\
\hline BR22N & 159.3 & $2.1 \%$ & $2.2 \%$ & $2.2 \%$ & $2.3 \%$ & $2.3 \%$ & $2.3 \%$ & $2.6 \%$ & $2.6 \%$ \\
\hline BR23 & 153.0 & $6.8 \%$ & $6.8 \%$ & $6.9 \%$ & $7.1 \%$ & $7.2 \%$ & $7.9 \%$ & $8.2 \%$ & $8.2 \%$ \\
\hline BA1 & 107.2 & $2.0 \%$ & $2.0 \%$ & $2.0 \%$ & $2.0 \%$ & $2.0 \%$ & $2.0 \%$ & $2.0 \%$ & $2.0 \%$ \\
\hline BA1N1 & 93.9 & $2.0 \%$ & $2.0 \%$ & $2.0 \%$ & $2.1 \%$ & $2.1 \%$ & $2.3 \%$ & $2.3 \%$ & $2.3 \%$ \\
\hline BA1N2 & 99.4 & $1.9 \%$ & $1.9 \%$ & $1.9 \%$ & $1.9 \%$ & $1.9 \%$ & $1.9 \%$ & $1.9 \%$ & $1.9 \%$ \\
\hline BA2 & 126.8 & $0.4 \%$ & $0.5 \%$ & $0.7 \%$ & $0.9 \%$ & $1.0 \%$ & $1.0 \%$ & $1.0 \%$ & $1.0 \%$ \\
\hline BA2E & 88.0 & $1.8 \%$ & $2.2 \%$ & $2.2 \%$ & $3.4 \%$ & $3.4 \%$ & $3.4 \%$ & $3.4 \%$ & $3.4 \%$ \\
\hline BA3 & 103.4 & $2.4 \%$ & $2.5 \%$ & $2.5 \%$ & $2.7 \%$ & $2.7 \%$ & $2.7 \%$ & $2.7 \%$ & $2.7 \%$ \\
\hline
\end{tabular}


Changes in specific impervious features

As impervious features were digitized they were assigned unique feature types that corresponded to the impervious surface type. This allowed for an analysis of the composition of the impervious feature types within Bronson Creek. Total impervious area was calculated for each of the 6 feature types: roads, buildings, sidewalks, driveways, parking lots, and miscellaneous features such as swimming pools, tennis courts and large patios that were visible at the digitizing resolution. Roads and buildings account for more than 60 percent of the total impervious area for Bronson Creek. Table 10 displays the makeup of the total impervious area for each feature type during each year.

Table 10 Percent of impervious area by category within the Bronson Creek watershed

\begin{tabular}{|c|c|c|c|c|c|c|c|c|}
\hline Surface & $\mathbf{1 9 9 4}$ & $\mathbf{1 9 9 5}$ & $\mathbf{1 9 9 6}$ & $\mathbf{1 9 9 7}$ & $\mathbf{1 9 9 8}$ & $\mathbf{1 9 9 9}$ & $\mathbf{2 0 0 0}$ & $\mathbf{2 0 0 1}$ \\
\hline \hline Buildings & $36.6 \%$ & $37.4 \%$ & $37.2 \%$ & $36.9 \%$ & $37.1 \%$ & $37.6 \%$ & $37.9 \%$ & $37.9 \%$ \\
\hline Driveways & $7.4 \%$ & $7.3 \%$ & $7.3 \%$ & $7.9 \%$ & $7.7 \%$ & $8.1 \%$ & $8.2 \%$ & $8.3 \%$ \\
\hline Miscellaneous & $0.8 \%$ & $0.8 \%$ & $0.8 \%$ & $0.9 \%$ & $0.9 \%$ & $0.9 \%$ & $0.9 \%$ & $0.9 \%$ \\
\hline Parking lots & $17.7 \%$ & $17.8 \%$ & $19.7 \%$ & $19.5 \%$ & $19.6 \%$ & $19.5 \%$ & $19.5 \%$ & $19.2 \%$ \\
\hline Roads & $31.9 \%$ & $31.3 \%$ & $29.4 \%$ & $28.7 \%$ & $28.6 \%$ & $27.3 \%$ & $26.9 \%$ & $27.0 \%$ \\
\hline Sidewalks & $5.6 \%$ & $5.4 \%$ & $5.6 \%$ & $6.1 \%$ & $6.2 \%$ & $6.6 \%$ & $6.7 \%$ & $6.7 \%$ \\
\hline
\end{tabular}

\section{Comparison to estimations procedures}

Effective impervious area (EIA), another index of urbanization, was calculated for Bronson Creek by Clean Water Services as part of their Watersheds 2000 project. An attempt was made to compare these EIA values to a set of values that were calculated with the Sutherland equations and digitized TIA values. This task was unsuccessful because of differences in the land use data that were used as the source of the EIA values. 


\section{Comparison of TIA values calculated from differing methods}

Another set of analysis was performed to identify if land use estimation procedures could produce results comparable to those calculated from direct digitizing. 2001 TIA values for Bronson Creek had already been digitized, so it was necessary to calculate TIA values from land use data. The zoning layer of the Metro Regional Land Information System (RLIS) dataset was used to produce these values.

The RLIS zoning layer contains 26 unique zoning classifications that describe land use at the tax lot level. 19 of these classifications have been assigned within the Bronson Creek Watershed. The 26 metro zoning classes are grouped into 7 generalized zoning classifications, all of which were assigned to taxlots within the Bronson Creek watershed.

The total area for each zoning classification was calculated for all 37 subbasins within the Bronson Creek watershed. At this point, the data represented the watershed if it were entirely built out. Data were then clipped with the RLIS developed land layer, which identified the taxlots that were actually developed to transform the data to 2001 conditions.

Several studies and engineering manuals have published average TIA values for general land use classifications for modeling and design scenarios. These values make it possible to convert land use area within a basin to TIA. The NRCS's values for the TR-55 model were used to calculate TIA for this project. The TR-55 model is a hydrologic model for small urban watersheds such as Bronson Creek (NRCS 1996). These values were chosen 
because conversion coefficients were available for a wider assortment of land use classifications than other options and the models' applicability to the Bronson Creek watershed. The RLIS land use data classes did offer exact matches to those defined by the NRCS, especially in the single family residential subgroup. Therefore, it was necessary to match the RLIS zoning classes to those published by the NRCS. The matched classes are presented in the Table 12 . 
Table 11 Imperviousness values assigned to RLIS land use classifications

\begin{tabular}{|c|c|c|c|}
\hline \multicolumn{2}{|c|}{26 regional classifications into which the zoning was generalized ${ }^{1}$} & \multirow{2}{*}{\begin{tabular}{l} 
Assigned \\
within \\
Bronson \\
\multicolumn{1}{c}{}
\end{tabular}} & \multirow{2}{*}{$\begin{array}{l}\text { Assigned } \\
\text { Imperviousness }^{2} \\
\\
0\end{array}$} \\
\hline FF & $\begin{array}{l}\text { Agriculture or Forestry- activities suited to commercial scale agricultural production, typically with lot sizes of } \\
30 \text { acres or more. }\end{array}$ & & \\
\hline RRFU & $\begin{array}{l}\text { Rural or Future Urban- residential uses permitted on rural lands or areas designated for future urban } \\
\text { development, with minimum lot sizes of one acre or more. }\end{array}$ & $\mathrm{V}$ & 16 \\
\hline SFR1 & Single Family 1- detached housing with minimum lot sizes from 20,000 square feet and up. & $\mathrm{V}$ & 16 \\
\hline SFR2 & Single Family 2- detached housing with minimum lot sizes ranging from 12,000 to 20,000 square feet. & $\mathrm{V}$ & 25 \\
\hline SFR3 & Single Family 3- detached housing with minimum lot sizes ranging from 8,500 to 12,000 square feet. & $\mathrm{V}$ & 30 \\
\hline SFR4 & Single Family 4- detached housing with minimum lot sizes from 6,500 to 8,500 square feet. & & 38 \\
\hline SFR5 & Single Family 5- detached housing with minimum lot sizes ranging from 5,500 to 6,500 square feet. & $\mathrm{V}$ & 38 \\
\hline SFR6 & Single Family 6- detached housing with minimum lot sizes from 4,000 to 5,500 square feet. & & 38 \\
\hline SFR7 & Single Family 7- detached housing with minimum lot sizes ranging from 0 to 4,000 square feet. & $\mathrm{V}$ & 38 \\
\hline MFR1 & $\begin{array}{l}\text { Multi-family 1- housing and or duplex, townhouse and attached single-family structures allowed outright. } \\
\text { Maximum net allowable densities range from } 11 \text { to } 25 \text { units per acre, with height limits usually set at } 21 / 2 \text { to } 3 \\
\text { stories. }\end{array}$ & $\mathrm{v}$ & 65 \\
\hline MFR2 & $\begin{array}{l}\text { Multi-family } 2 \text { - housing accommodating densities ranging from } 25 \text { to } 50 \text { units per acre. Buildings may exceed } \\
\text { three stories in height. }\end{array}$ & $\mathrm{V}$ & 65 \\
\hline MFR3 & Multi-family 3 - housing accommodating densities ranging from 50 to 100 units. & & 65 \\
\hline MFR4 & $\begin{array}{l}\text { Multi-family 4- housing accommodating densities greater than } 100 \text { units. This is the densest of the multi-family } \\
\text { zones and would require greater use of vertical space and buildings with multiple stories. }\end{array}$ & & 65 \\
\hline $\mathrm{CN}$ & $\begin{array}{l}\text { Neighborhood Commercial- small scale commercial districts permitting retail and service activities such as } \\
\text { grocery stores and laundromats supporting the local residential community. Floor space and/or lot size is } \\
\text { usually limited from 5,000 to } 10,000 \text { square feet. }\end{array}$ & $\mathrm{v}$ & 85 \\
\hline $\mathrm{CG}$ & $\begin{array}{l}\text { General Commercial- larger scale commercial districts, often with a more regional orientation for providing } \\
\text { services. Businesses offering a wide variety of goods and services are permitted and include highway and strip } \\
\text { commercial zones. }\end{array}$ & $\mathrm{V}$ & 85 \\
\hline $\mathrm{CC}$ & $\begin{array}{l}\text { Central Commercial- allows a full range of commercial activities typically associated with central business } \\
\text { districts. More restrictive than general commercial in the case of large lot and highway oriented uses, but usally } \\
\text { allows multi-story development. }\end{array}$ & $\mathrm{v}$ & 85 \\
\hline
\end{tabular}




\begin{tabular}{|c|c|c|c|}
\hline \multicolumn{2}{|c|}{26 regional classifications into which the zoning was generalized ${ }^{1}$} & \multirow{2}{*}{\begin{tabular}{l}
$\begin{array}{l}\text { Assigned } \\
\text { within } \\
\text { Bronson }\end{array}$ \\
\multicolumn{1}{c}{$\mathrm{v}$}
\end{tabular}} & \multirow{2}{*}{$\begin{array}{c}\begin{array}{c}\text { Assigned } \\
\text { Imperviousness }\end{array} \\
85\end{array}$} \\
\hline $\mathrm{CO}$ & $\begin{array}{l}\text { Office Commercial- districts accommodating a range of business, professional and medical office facilities, } \\
\text { typically as a buffer between residential areas and more intensive uses. }\end{array}$ & & \\
\hline IL & $\begin{array}{l}\text { Light Industrial- districts permitting warehousing and light processing and fabrication activities. May allow } \\
\text { some commercial activities. }\end{array}$ & & 85 \\
\hline $\mathrm{IH}$ & $\begin{array}{l}\text { Heavy Industrial- districts permitting light industrial and more intensive industrial activities such as bottling, } \\
\text { limited chemical processing, heavy manufacturing and similar uses. }\end{array}$ & $\mathrm{v}$ & 72 \\
\hline IMU & Mixed Use Industrial- districts accommodating a mix of light manufacturing, office and retail uses. & $\mathrm{V}$ & 72 \\
\hline IA & $\begin{array}{l}\text { Industrial Area- districts designated exclusively for manufacturing, industrial, warehouse and distribution } \\
\text { related operations. }\end{array}$ & & 72 \\
\hline MUC1 & Mixed Used Center 1- combines residential and employment uses in town centers, main streets and corridors. & $\mathrm{v}$ & 72 \\
\hline MUC2 & Mixed Use Center 2- combines residential and employment uses in light rail station areas and regional centers. & $\mathrm{v}$ & 72 \\
\hline MUC3 & $\begin{array}{l}\text { Mixed Use 3- combines residential and employment uses in central city locations. Mixed use is weighted } \\
\text { toward residential development. }\end{array}$ & & 72 \\
\hline POS & Parks and Open Space & $\mathrm{v}$ & 0 \\
\hline $\mathrm{PF}$ & Public Facilities & $\mathrm{v}$ & 85 \\
\hline
\end{tabular}

(1) from Metro 2003

(2) from NRCS 1996 


\section{$\underline{\text { Results of Estimation Analysis }}$}

TIA values that were estimated from the land use classes were compared to those produced from digitizing in order to determine if the two methods generate similar results. TIA values are useful indicators of urbanization and there is a large discrepancy in the amount of time required to produce TIA values from the 2 methods. It took over 40 hours to digitize all impervious surfaces within the Bronson Creek watershed from one year of aerial photography, while TIA values were calculated from land use class in less than 8 hours.

There is a considerable difference between the output TIA values from the 2 methods. The results from the direct digitizing method are more dependable, so all analysis and comparisons were made using this assumption.

TIA was underestimated in subbasins dominated with single family residential land use and overestimated in subbasins with mixed use and industrial land use. Only a general analysis was performed on the ability to estimate TIA values using land use data. The TIA values were grouped into the common classification system proposed by Schuler and Holland (2000) where streams surrounded areas that are less than 11\% impervious are considered sensitive, while those surrounded by land with impervious levels greater than $26 \%$ are non-supporting. Streams that fall into the middle category of $11-25 \%$ are classified as impacted using the classification scheme. Figure 10 displays the general 
results of this analysis as well as land use classifications for developed land within the watershed.

Table 12 Results of Comparison of Digitized TIA and TIA estimated from Land Use

\begin{tabular}{|c|c|c|c|}
\hline SUBID & Digitized TIA\% & Estimated TIA\% & Difference \\
\hline BR1 & $40.7 \%$ & $56.0 \%$ & $-15.3 \%$ \\
\hline BR2 & $2.2 \%$ & $25.0 \%$ & $-22.8 \%$ \\
\hline BR3 & $9.5 \%$ & $41.0 \%$ & $-31.5 \%$ \\
\hline BR4 & $23.3 \%$ & $50.0 \%$ & $-26.7 \%$ \\
\hline BR5 & $15.5 \%$ & $41.0 \%$ & $-25.5 \%$ \\
\hline BR6 & $28.3 \%$ & $58.0 \%$ & $-29.7 \%$ \\
\hline BR7 & $32.9 \%$ & $60.0 \%$ & $-27.1 \%$ \\
\hline BR8 & $40.0 \%$ & $56.0 \%$ & $-16.0 \%$ \\
\hline BR9 & $25.8 \%$ & $61.0 \%$ & $-35.2 \%$ \\
\hline BR9W & $70.2 \%$ & $84.0 \%$ & $-13.8 \%$ \\
\hline BR10W & $25.4 \%$ & $53.0 \%$ & $-27.6 \%$ \\
\hline BR11 & $1.6 \%$ & $19.0 \%$ & $-17.4 \%$ \\
\hline BR11N & $32.5 \%$ & $44.0 \%$ & $-11.5 \%$ \\
\hline BR11S & $36.5 \%$ & $42.0 \%$ & $-5.5 \%$ \\
\hline BR12 & $26.1 \%$ & $37.0 \%$ & $-10.9 \%$ \\
\hline BR12E & $32.3 \%$ & $45.0 \%$ & $-12.7 \%$ \\
\hline BR13 & $27.0 \%$ & $40.0 \%$ & $-13.0 \%$ \\
\hline BR14N & $47.4 \%$ & $51.0 \%$ & $-3.6 \%$ \\
\hline BR15 & $23.4 \%$ & $32.0 \%$ & $-8.6 \%$ \\
\hline BR16 & $25.8 \%$ & $41.0 \%$ & $-15.2 \%$ \\
\hline $\mathrm{BR} 17 \mathrm{~N}$ & $27.9 \%$ & $44.0 \%$ & $-16.1 \%$ \\
\hline BR18 & $9.6 \%$ & $21.0 \%$ & $-11.4 \%$ \\
\hline BR18E & $4.7 \%$ & $13.0 \%$ & $-8.3 \%$ \\
\hline BR19N & $7.5 \%$ & $39.0 \%$ & $-31.5 \%$ \\
\hline BR20 & $2.7 \%$ & $19.0 \%$ & $-16.3 \%$ \\
\hline BR21 & $2.1 \%$ & $20.0 \%$ & $-17.9 \%$ \\
\hline BR21N & $0.6 \%$ & $10.0 \%$ & $-9.4 \%$ \\
\hline BR22 & $1.0 \%$ & $29.0 \%$ & $-28.0 \%$ \\
\hline BR22E & $1.5 \%$ & $10.0 \%$ & $-8.5 \%$ \\
\hline BR22N & $0.6 \%$ & $10.0 \%$ & $-9.4 \%$ \\
\hline BR23 & $2.9 \%$ & $27.0 \%$ & $-24.1 \%$ \\
\hline BA1 & $0.4 \%$ & $15.0 \%$ & $-14.6 \%$ \\
\hline BA1N1 & $0.5 \%$ & $8.0 \%$ & $-7.5 \%$ \\
\hline BA1N2 & $0.4 \%$ & $3.0 \%$ & $-2.6 \%$ \\
\hline BA2 & $0.1 \%$ & $2.0 \%$ & $-1.9 \%$ \\
\hline BA2E & $0.8 \%$ & $3.0 \%$ & $-2.2 \%$ \\
\hline BA3 & $0.6 \%$ & $6.0 \%$ & $-5.4 \%$ \\
\hline
\end{tabular}




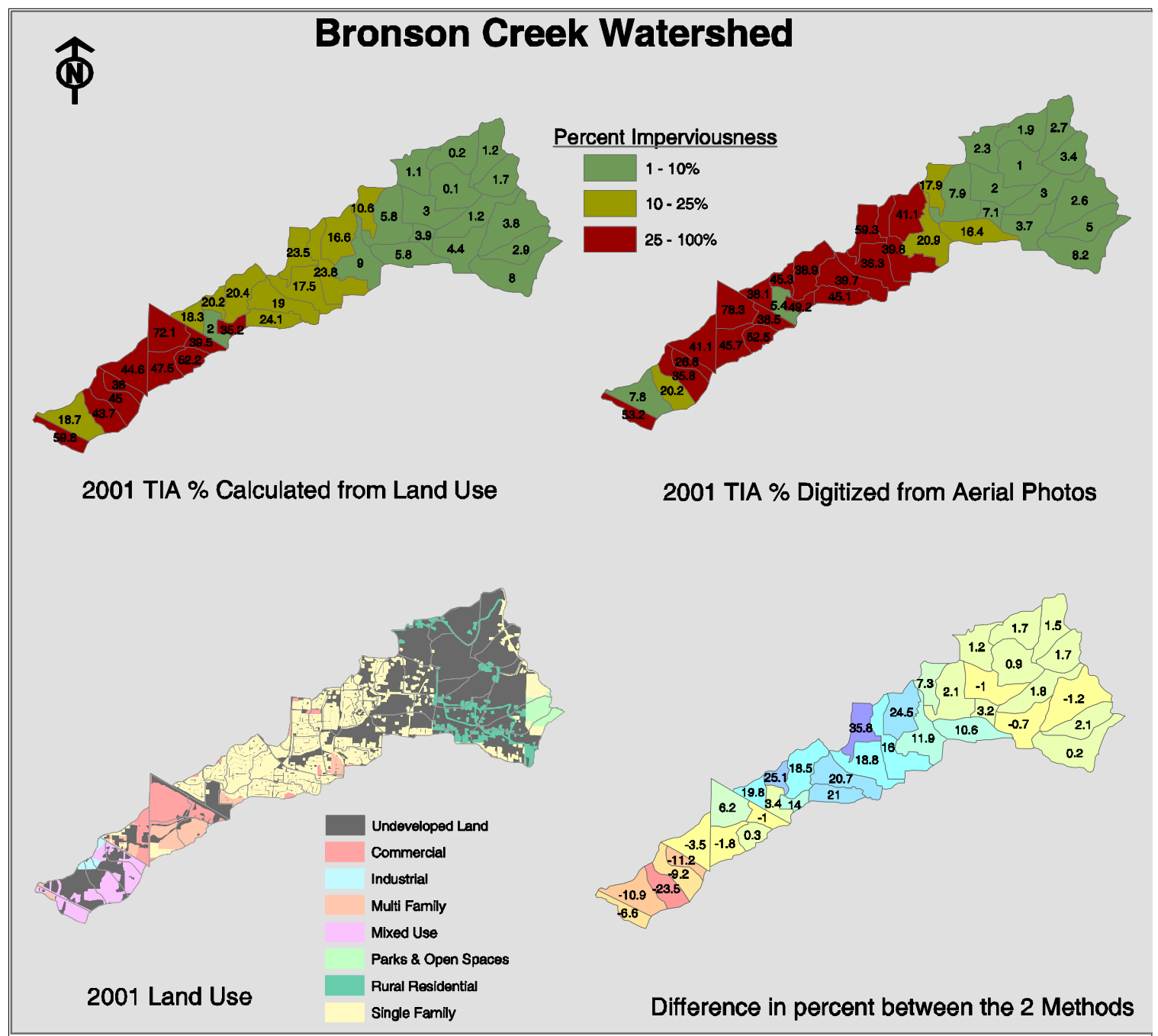

Figure 10 Comparison of Methods used to calculate total impervious surface area 


\section{Water Quality Analysis}

\section{A. Introduction}

The water quality analysis portion of the project was undertaken in an attempt to answer two key questions: 1) Has water quality changed over time? 2) Is there a relationship between water quality and the amount of total impervious cover within the watershed? Attempts were made to reduce the effect of seasonal variation, which could decrease the power of the testing procedures and mask a trend or significant association.

\section{B. Data Clustering}

Prior to performing analysis of the water quality data it was necessary to account for the effects of seasonal variation that is intrinsic in environmental data of this type.

Traditionally, water quality studies have clustered months into periods, such as wet and dry season and analyzed the data during the specified periods. In order to account for and reduce the impact of seasonal variation for this project, data were grouped into sets of months where water quality values were similar and water quality levels approached or exceeded critical levels. Only the data that met these criteria were used in the analysis.

All statistical analysis for this project was performed using SPSS (v.11.0) or Analyse-It, a statistical add-on for Microsoft Excel. Prior to examination, the raw data that were submitted by CWS were formatted in Microsoft Excel to facilitate analysis. The eight variables of interest were extracted from the master database containing all 39 water quality parameters, and data were formatted to be read and analyzed by SPSS. 


\section{$\underline{\text { Methods }}$}

Seasonal groupings were created for each water quality variable to isolate time periods where the values of a variable were statistically similar. The groupings were produced by performing a non-parametric analysis of variance (ANOVA) with a multiple comparison test on the data for each for each of the 8 water quality variables of interest (Helsel and Hirsch 2002). Because of the non-normal distribution associated with this type of environmental data, the non-parametric rank-factor test was used (Helsel and Hirsch 2002). An analysis of variance (ANOVA) was performed on the ranks of the data rather that than on the data itself to increase the power of the test. The non-parametric version of ANOVA tested whether the mean rank differed between groups (months) rather than just the mean of the data (Helsel and Hirsch 2002). This technique also allowed for proper analysis of censored data which was present for ammonia, total phosphorous, orthophosphate, fecal coli form, and E. coli. Because the ANOVA was performed on the ranks rather that the measured values, the presence of minimum detection limits (MDL) in the datasets did not skew the results of the ANOVA. The use of the rank-factor test also allowed for a multiple comparison test to be run which was necessary to determine which groups (months) were similar to others.

The Tukey multiple comparison test was run when the null hypothesis $\left(\mathrm{H}_{\mathrm{o}}\right.$ : water quality for a variable is the same during all months) was rejected by ANOVA. The multiple comparison tests were performed to determine which, if any, of the months exhibited like 
behavior. The null hypothesis was rejected for all eight water quality variables during the seven years sampling period, which was expected. Not rejecting the null hypothesis would have meant that the variables exhibited no seasonal variation and that the values of a particular variable were constant throughout the year. It was therefore necessary to perform the Tukey multiple comparison test on all variables to determine which months had like water quality. The purpose of this analysis was to create subsets of the data where values where similar from month to month. Groupings were performed when 1) months exhibited like behavior, 2) the months were temporally connected, and 3) the values during a grouping exceeded a TMDL or critical level. Temperature was the only one of the eight variables where the multiple comparison test yielded significant groupings that met the test specifications. Figure 9 shows the results of the multiple comparison test on temperature. The output for the remaining seven variables resulted in inconclusive groupings, where a month was part of several multiple comparison subsets. The results of Tukey multiple comparison tests for these variables are presented in Appendix A. 


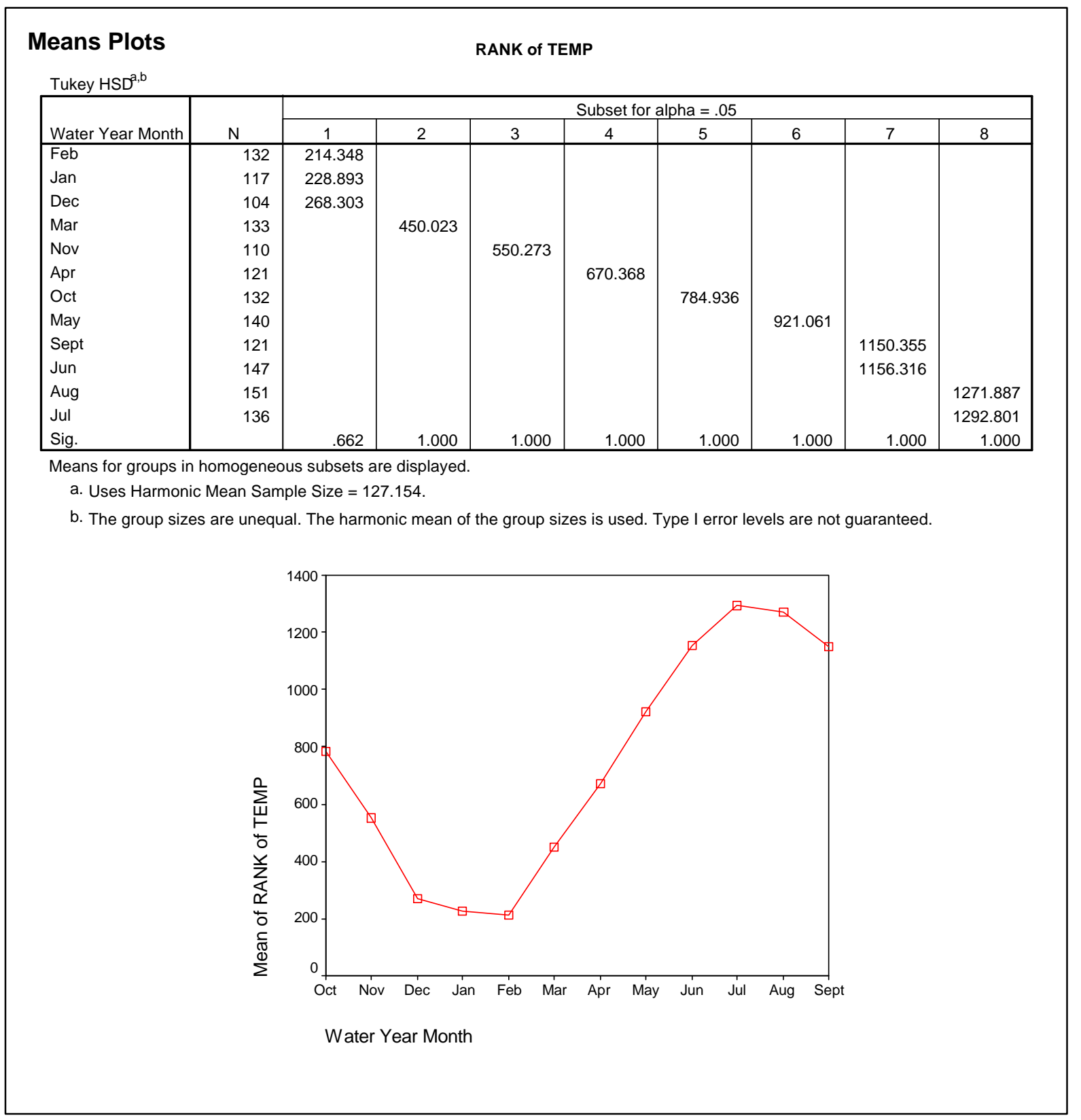

Figure 11 Multiple comparison output for temperature 
For the remaining seven variables, seasonal groupings were determined by interpreting monthly box plots along with the results from the multiple comparison tests. Box plots were constructed for each of the variables using all data $(1994-2001)$ at all nine of the sampling sites. Figures $12-18$ show the monthly box plots that were used to determine the periods of like behavior for the variables that could not be conclusively grouped by the multiple comparison tests.

Water temperature

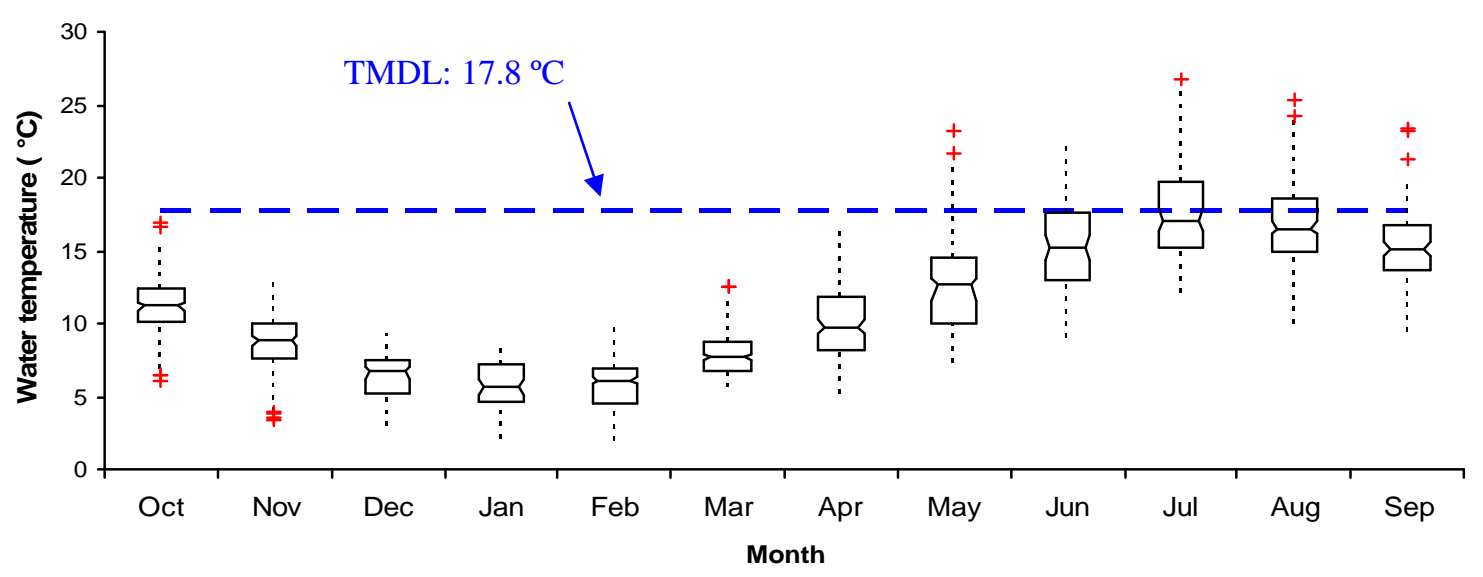

Figure 12 Water temperature box plot 
Total suspended solids

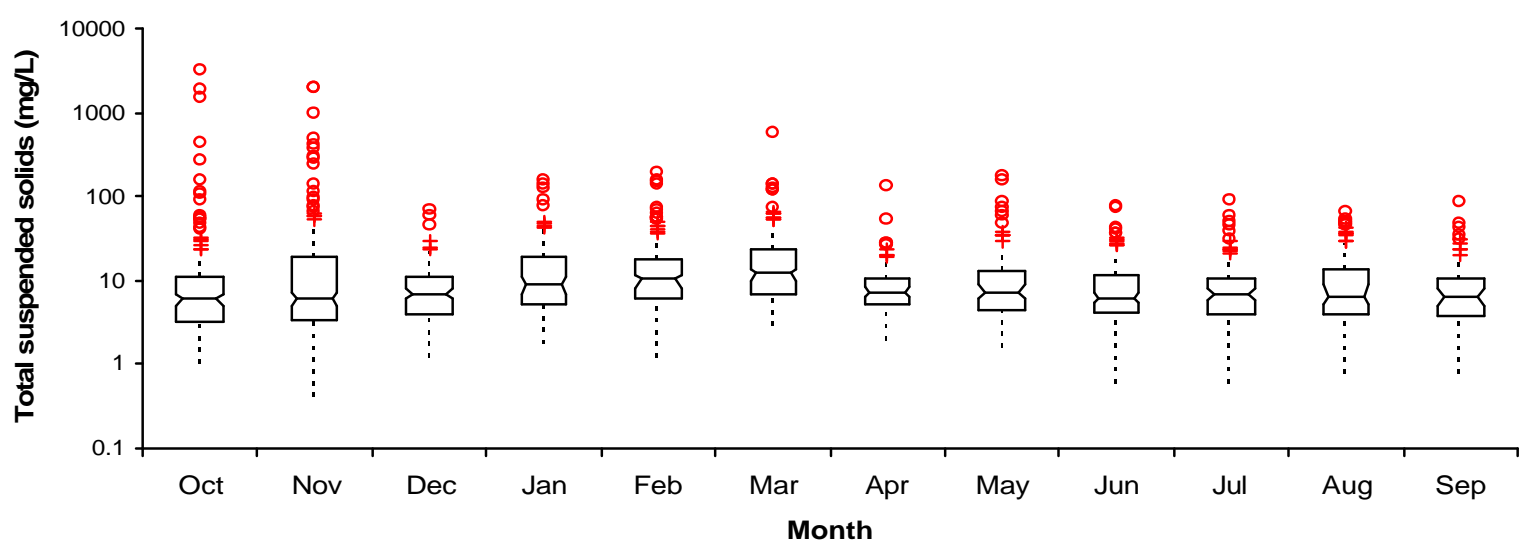

Figure 13 Total suspended solids Box plot

Total Phosphate as Phosphorus

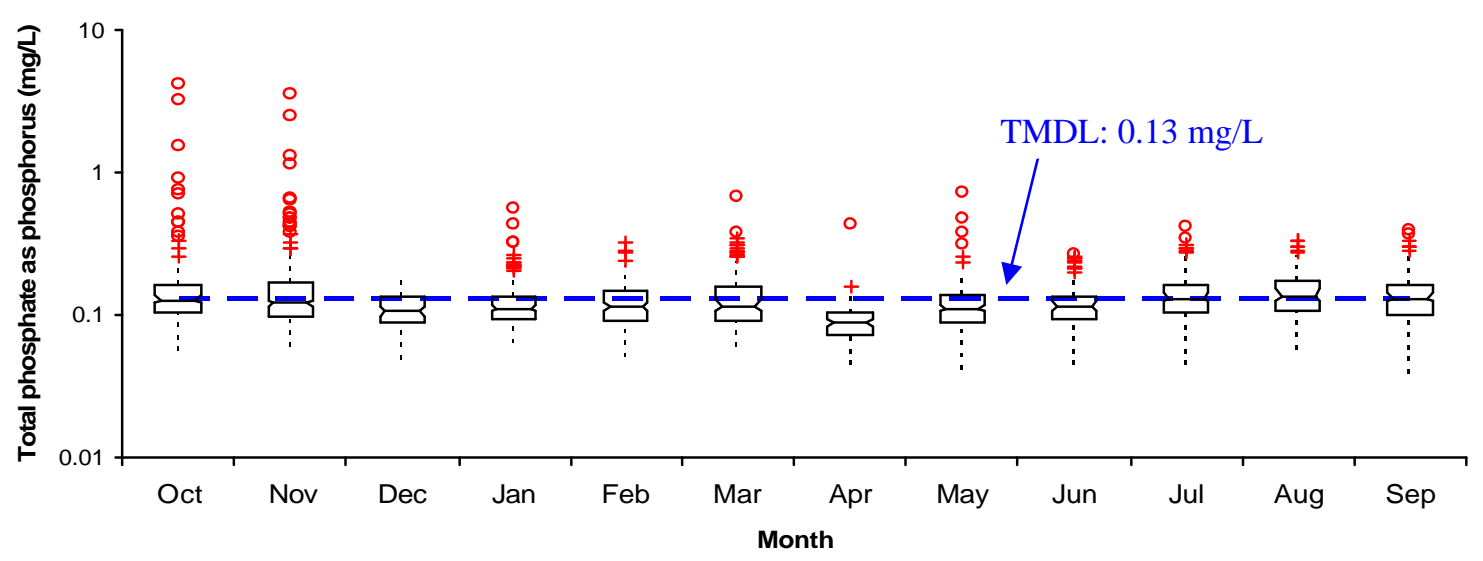

Figure 14 Total phosphorous boxplot 
Soluble ortho-phosphate

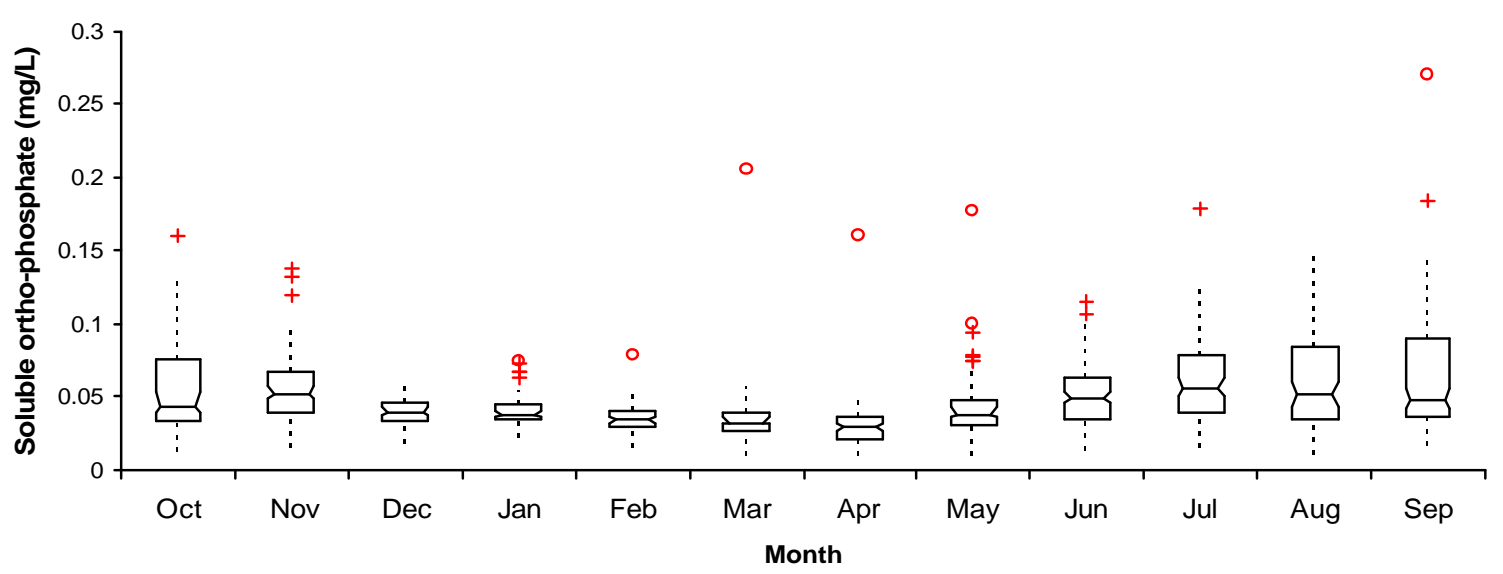

Figure 15 Soluable ortho-phosphate boxplot

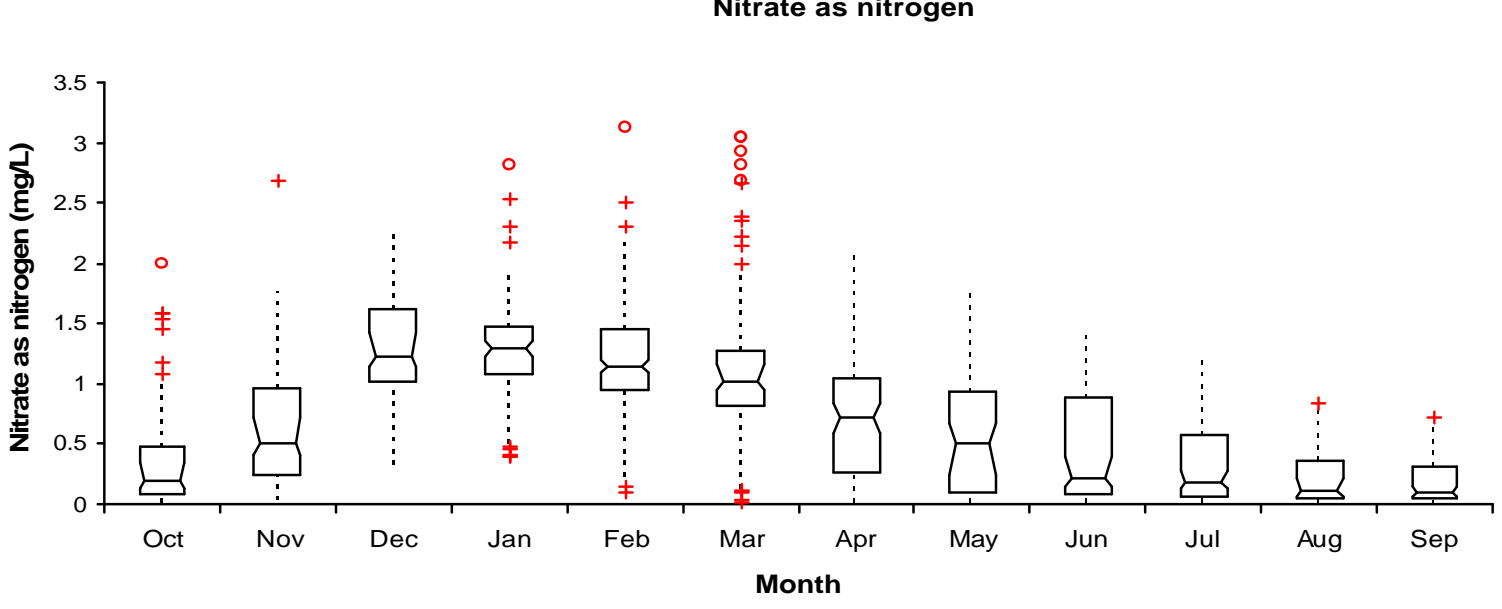

Figure 16 Nitrate Boxplot 
Ammonia as Nitrogen

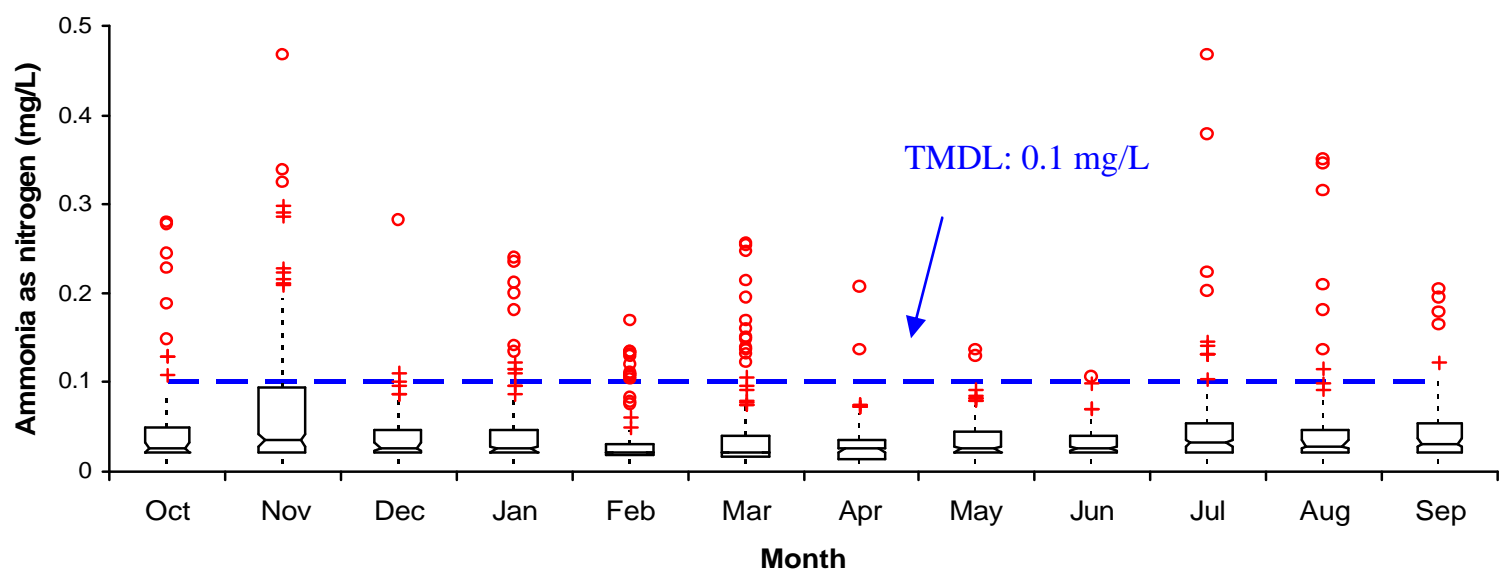

Figure 17 Ammonia Boxplot

E. coliform agar

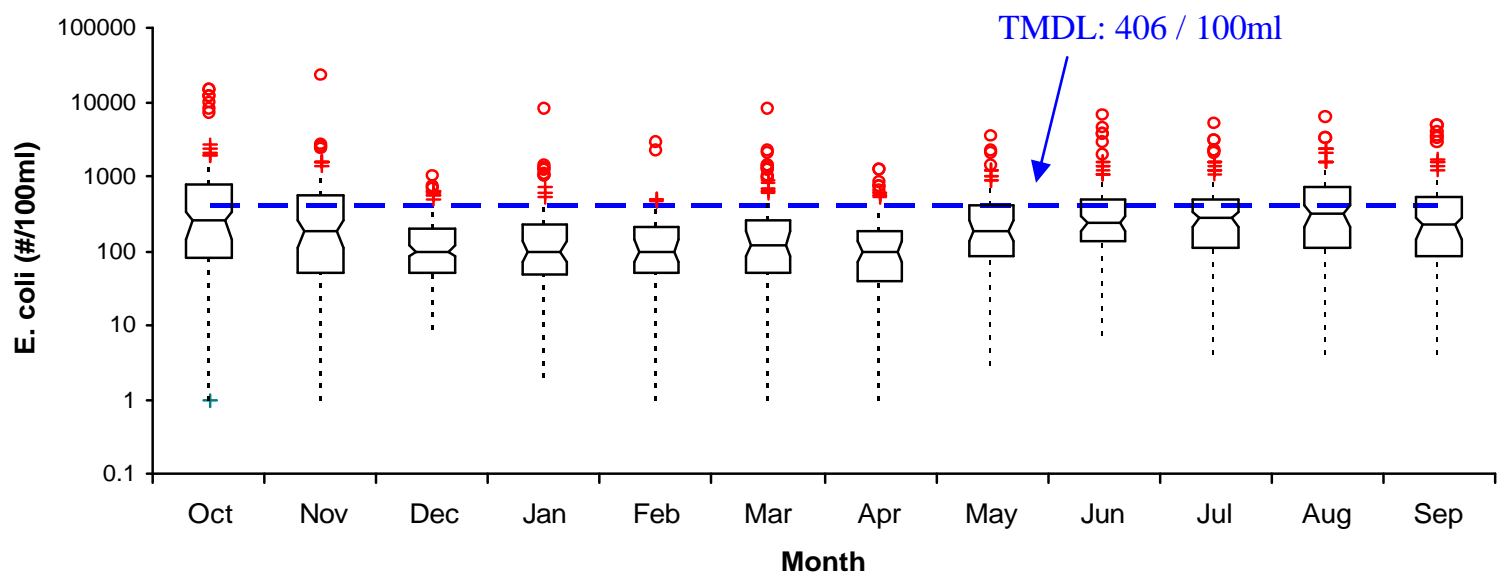

Figure 18 E. Coli Boxplot

Table 14 lists the final monthly groupings that resulted from the ANOVA and box plot analysis. Data that fell within the selected months were combined and used in the subsequent trend analysis and the association analysis between water quality and total impervious area. 
Table 13 Clusters and method for each variable

\begin{tabular}{|l|c|c|}
\hline WQ Variable & Clustering Method & Period \\
\hline Temperature & ANOVA & July - Aug \\
\hline OP & Box Plots & July - Nov \\
\hline TSS & Box Plots & July - Nov \\
\hline Fecal Coliform & Box Plots & July - Nov \\
\hline Ammonia & Box Plots & July - Nov \\
\hline TP & Box Plots & July - Nov \\
\hline E. Coli & Box Plots & July - Nov \\
\hline Nitrogen & Box Plots & Dec - Jan \\
\hline
\end{tabular}

The non-parametric rank-factor test with multiple comparison output was also run on the data to determine if there were any significant similarities between variables longitudinally up or downstream. The output of this part of the analysis showed differences but they were inconclusive with regard to combining locations. The results have been included in Appendix B for review.

\section{Trend Analysis}

The initial part of the analysis was performed to determine if water quality has changed within Bronson Creek over time; that is, whether there is a trend. This was an important question to answer prior to performing other analysis, in order to understand how the eight water quality variables have behaved during the seven year study period.

\section{Methods}

There were many statistical techniques available to determine if a trend was present for the data. For this project, the unadjusted Mann - Kendall test was used. This test 
determined if the median value for one of the 8 water quality variables changed over time. Because it uses the Kendalls $t$, it measures a monotonic relationship between the two variables, water quality $(\mathrm{Y})$ and time $(\mathrm{T})$. This is different from the standard Pearson's Correlation statistic which only measures a linear association between two variables. The Mann - Kendall test was chosen over other available techniques for two crucial reasons; 1) the presence of non-parametric data and 2) the presence of censored data (Helsel and Hirsch 2002).

The Kendall's t statistics, which were not adjusted for flow, were calculated for each water quality variable and time at each sampling site during the selected seasons. Flow data were not available for this analysis, which prevented for the correction of an important exogenous variable and therefore reduced the power of the test (Helsel and Hirsch 2002). However, analysis of precipitation data suggests that no trend in flow exists for the watershed.

\section{$\underline{\text { Results }}$}

The Kendall's analysis found several decreasing trends within Bronson Creek during the 1994 - 2001 study period (Table 15). The majority of the significant trends were negative which signify decreasing sample values over time. For the variables in this study, all of which are considered distressed as sample values increase, these results suggest that water quality improved over the seven year study period. Most notable is the relationship of nitrate/nitrogen over time. All nine sampling sites exhibited significant 
(0.05) negative trends during December and January. Five of the nine sites had statistically significant trends for Ammonia. The uppermost 4 sample sites all had negative trends while the site at Bronson and $205^{\text {th }}$ which was the furthest downstream site (river mile 0.1) had a significant positive trend, indicating that nitrogen is monotonically increasing over time for data collected over the period from July to November.

E. Coli, total phosphorus, and TSS all has significant negative trends at multiple locations. A significant positive trend was found at the Bannister at $124^{\text {th }}$ site for soluble phosphorous and a negative trend was found at West Union. The only variable that did not exhibit a trend at ant of the sample sites was temperature.

Table 14 Association between Water Quality and Time (Trend) Kendall's t statistic computed for the indicated water quality variable at each site BOLD indicates significant correlation (trend) at 0.05 level during the specified time period (1994-2001)

\begin{tabular}{|r|c|c|c|c|c|c|c|c|}
\hline \multicolumn{2}{|c|}{} & \multicolumn{7}{c|}{ Variable } \\
\cline { 2 - 9 } \multicolumn{2}{|c|}{ Temp. } & TSS & Total P & Soluble P & Nitrogen & Ammonia & E. coli \\
\hline BA 124th & 6 & -0.217 & -0.022 & 0.024 & $\mathbf{0 . 2 2 8}$ & $\mathbf{- 0 . 6 6 9}$ & $\mathbf{- 0 . 4 6 9}$ & -0.153 \\
Saltzman & 5.6 & -0.179 & -0.079 & -0.072 & 0.096 & $\mathbf{- 0 . 2 7 5}$ & $\mathbf{- 0 . 2 5 9}$ & -0.031 \\
BA. Laid & 5.5 & -0.246 & -0.105 & -0.130 & 0.040 & $\mathbf{- 0 . 3 6 5}$ & $\mathbf{- 0 . 2 7 4}$ & $\mathbf{- 0 . 2 8 2}$ \\
143rd & 4 & 0.002 & $\mathbf{- 0 . 3 1 0}$ & $\mathbf{- 0 . 3 2 5}$ & -0.033 & $\mathbf{- 0 . 5 6 2}$ & $\mathbf{- 0 . 3 4 6}$ & -0.056 \\
W. Union & 3.5 & -0.074 & $\mathbf{- 0 . 2 6 8}$ & $\mathbf{- 0 . 4 5 0}$ & $\mathbf{- 0 . 3 6 1}$ & $\mathbf{- 0 . 5 5 2}$ & -0.031 & $\mathbf{- 0 . 3 6 4}$ \\
B. Park & 2.2 & 0.005 & 0.059 & $\mathbf{- 0 . 1 5 6}$ & -0.049 & $\mathbf{- 0 . 5 5 9}$ & 0.075 & $\mathbf{- 0 . 2 8 2}$ \\
185th & 1.5 & 0.088 & -0.098 & -0.044 & -0.018 & $\mathbf{- 0 . 6 1 7}$ & -0.006 & 0.080 \\
Walker & 1.2 & -0.005 & -0.016 & 0.018 & 0.108 & $\mathbf{- 0 . 5 6 1}$ & 0.047 & -0.082 \\
205th & 0.1 & 0.209 & 0.103 & 0.061 & 0.126 & $\mathbf{- 0 . 4 6 6}$ & $\mathbf{0 . 2 5 8}$ & 0.117 \\
\hline
\end{tabular}




\section{Correlation between TIA and Water Quality}

\section{Methods}

TIA and water quality statistics from the initial part of the project were used to determine if a relationship exists between TIA and water quality in Bronson Creek watershed. Again, the Kendalls's t correlation statistic was used because of its nonparametric strength and ability to measure monotonic relationships. Pearson's correlation coefficient was not used because it is only as measure of linear association between two variables, in this case TIA and a water quality variable such as water temperature. The purpose of this analysis was to determine if increases in urbanization have caused changes in water quality. Pearson's coefficient is strictly applicable to linear association, while Kendall's $\mathrm{t}$ allowed for any monotonic relationship (exponential, linear, power) to be identified (Helsel and Hirsch 2002).

In order to test for an association, it was necessary to cluster the TIA data into subsets that could be compared with the water quality data. TIA values were calculated for each of Bronson Creek's 33 subbasins over the 7 year period. Water quality statistics were calculated at the eight sampling sites along Bronson Creek over the same period of record. Each water quality sample value was matched to a TIA value prior to performing the correlation analysis. Yearly subbasin TIA values were matched to the appropriate water quality sample during the same year. Each of the 33 subbasins was linked to one of the 8 sampling sites before running statistics on the data. Water quality data were limited to the seasons that were used in the trend analysis. Because instream water quality is controlled by upstream water quality (citation) each sampling station was linked to all 
upstream subbasins. Therefore, the downstream sampling site (Bronson at $205^{\text {th }}$, River Mile 0.1) was linked to all 33 subbasins within Bronson Creek Watershed and the most upstream sampling site (Bannister Creek at $124^{\text {th }}$, River mile 6.0) was linked to the 3 subbasins in the headwaters of Banister Creek. This procedure was followed for all samples during all years. Figure 19 shows the location of the sampling sites and associated subbasins used in the analysis. 


\section{Subbasins Used in the Total Impervious Surface Water Quality Correlation}

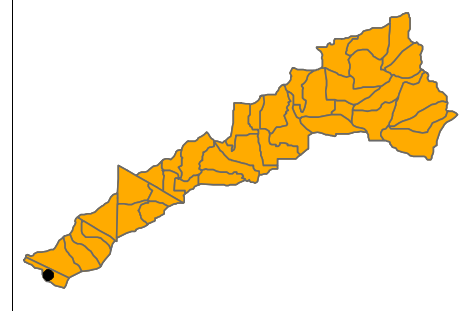

Bronson @ 205th

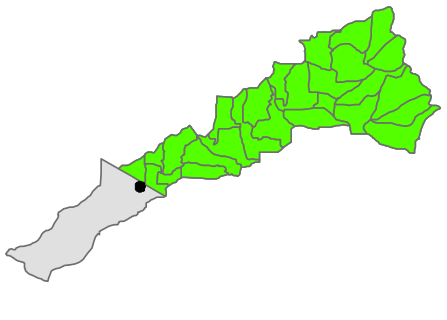

Bronson @ Bronson Park

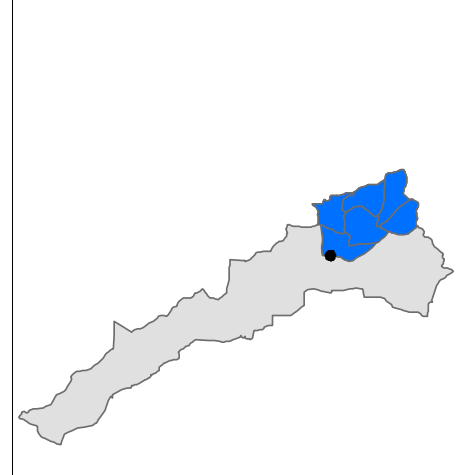

Bannister @ Laidlaw

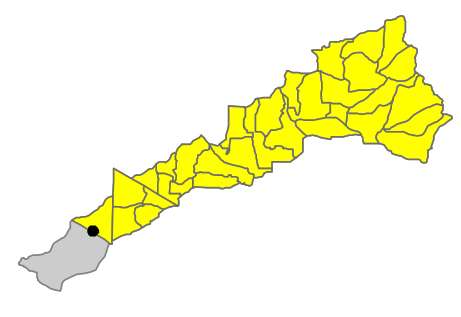

Bronson@Walker

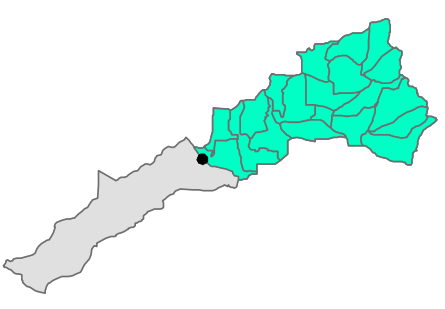

Bronson@ West Union

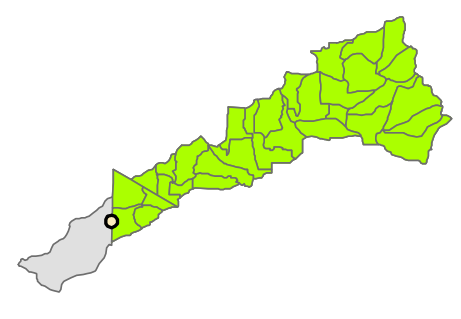

Bronson @ 185th

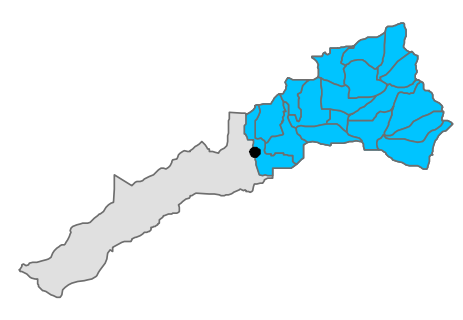

Bronson @ 143rd

Only the subbasins upstream of the sampling stations were used in the correlation

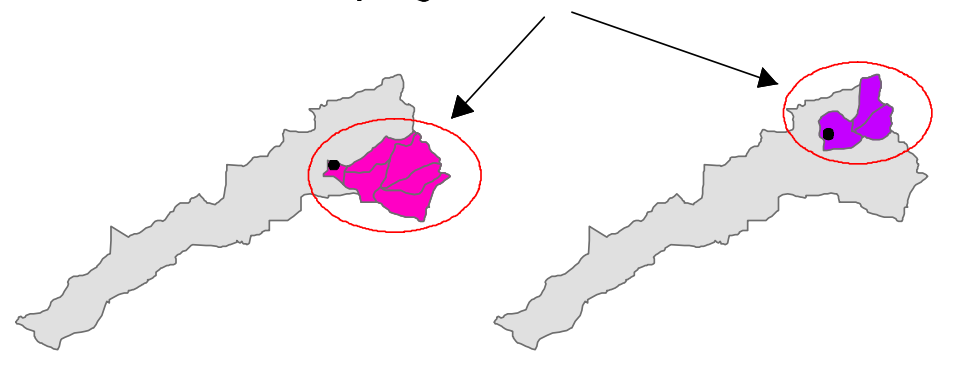

Bronson @ Saltzman

Bannister @ 124th

Figure 19 Location of the sampling sites and associated subbasins 
Kendall's t correlation statistic was computed for every water quality statistic at each of the 9 sampling sites along Bronson Creek. In total, 63 correlation statistics were produced with statistical correlation levels at 0.05 .

\section{$\underline{\text { Results }}$}

A statistically significant association (5\% level) was found at least one sampling site for all of the 7 variables and 27 of the 63 values were deemed significant at the 0.05 level.

Results of the Kendall's t analysis are presented in Table 16

\section{Table 15 Association between Water Quality and TIA}

Kendall's t statistic computed for the indicated water quality variable at each site BOLD indicates significant correlation at 0.05 level during the specified time period (1994-2001)

\begin{tabular}{|r|c|c|c|c|c|c|c|c|}
\hline \multicolumn{2}{|c|}{} & \multicolumn{7}{c|}{ Variable } \\
\cline { 3 - 9 } \multicolumn{2}{|c|}{ Location } & Temp. & TSS & Total P & Soluble P & Nitrogen & Ammonia & E. coli \\
\hline BA 124th & 6 & -0.288 & 0.012 & -0.140 & $\mathbf{0 . 2 8 0}$ & $\mathbf{- 0 . 4 4 9}$ & $\mathbf{- 0 . 7 5 6}$ & -0.005 \\
Saltzman & 5.6 & $\mathbf{- 0 . 2 9 6}$ & -0.172 & -0.038 & $\mathbf{0 . 2 6 9}$ & $\mathbf{- 0 . 4 2 3}$ & $\mathbf{- 0 . 3 0 5}$ & -0.003 \\
BA. Laid & 5.5 & -0.255 & -0.099 & -0.148 & 0.033 & $\mathbf{- 0 . 2 4 8}$ & $\mathbf{- 0 . 3 7 8}$ & $\mathbf{- 0 . 3 0 4}$ \\
143rd & 4 & 0.027 & $\mathbf{- 0 . 3 2 9}$ & $\mathbf{- 0 . 3 2 5}$ & -0.022 & $\mathbf{- 0 . 6 1 7}$ & $\mathbf{- 0 . 3 5 0}$ & -0.048 \\
W. Union & 3.5 & -0.074 & $\mathbf{- 0 . 2 7 3}$ & $\mathbf{- 0 . 4 7 2}$ & $\mathbf{- 0 . 3 4 2}$ & $\mathbf{- 0 . 6 4 7}$ & 0.009 & $\mathbf{- 0 . 3 6 6}$ \\
B. Park & 2.2 & 0.030 & 0.064 & $\mathbf{- 0 . 1 8 1}$ & 0.062 & $\mathbf{- 0 . 6 5 8}$ & 0.107 & $\mathbf{- 0 . 2 9 7}$ \\
185th & 1.5 & 0.124 & -0.125 & -0.072 & -0.035 & $\mathbf{- 0 . 6 9 2}$ & -0.029 & 0.078 \\
Walker & 1.2 & 0.034 & -0.044 & 0.001 & 0.109 & $\mathbf{- 0 . 6 6 2}$ & 0.029 & -0.096 \\
205th & 0.1 & $\mathbf{0 . 2 7 0}$ & 0.104 & 0.073 & 0.149 & $\mathbf{- 0 . 5 5 6}$ & $\mathbf{0 . 2 9 5}$ & 0.154 \\
\hline
\end{tabular}

Nitrogen was the only variable with a statistically significant association with TIA at all sites over the seven year period. The output of this analysis was unexpected when taking the published literature into account (Schuler and Holland 2001b, Arnold and Gibbons 1996). Water quality and TIA within Bronson Creek watershed exhibited a negative association over the seven year period. Of the 27 significant Kendall's values, 25 of the 
statistics were negative while only 2 of the 63 statistics align themselves with the literature and exhibit a positive correlation (0.05 significance). 


\section{Implications and Recommendations}

\section{A. Discussion of negative trends}

The dramatic decline in nitrogen levels within the Bronson Creek watershed are most likely the result of conversion from agricultural to residential land use. During the NWQA study of the Willamette Basin, the USGS found increasing nitrate concentrations as the percent area of agricultural use within the basin increased. As lands have been converted from agriculture, fertilizer application within the watershed has been reduced, which may account for the reduction in the amount of nitrogen entering Bronson Creek (Weintz et al. 1998).

In the 2001 CWS found declining trends for unadjusted total phosphorous, soluble phosphorous, and ammonia (May-Oct) for Rock Creek watershed from 1986 to 2000. A negative trend was also found for ammonia (Nov-April) during the same period. Similar results were found during this study. Negative trends were found for phosphorous at sites in the mid watershed (RM 2.2-4.0) and for ammonia at sites in the upper watershed (RM 4.0-6.0) (Aroner 2001).

Management practices have changed as a result of TMDL requirements, National Discharge Elimination System (NPDES) permits, and Clean Water Service's storm water management programs (CWS 2001b). These changes may be responsible for the results of the Kendall's correlation analysis. 
Clean Water Services has implemented many best management practices within their service area to reduce the release of pollutants. Water quality facilities have been constructed with new development, erosion control programs have been put in place, storm water management practices have been updated, conversion from septic to sewer has been encouraged, policies have been implemented to reduce and discourage pesticide and herbicide use, a riparian management program has been enacted, and maintenance programs have been established to keep the stormwater system operational at optimum levels (CWS 2001a).

Several BMPs were enacted exclusively within Bronson Creek watershed as part of a pilot program to test the effectiveness of stormwater treatment facilities and other BMPs (CWS 2001b). The Bronson Watershed Project began in 1995 in an attempt to assess the impacts of urbanization of streams. According to CWS, the purpose of the study was to "advance the scientific understanding of sediment-based stream systems, which are typical of the Tualatin River Basin" (CWS 2001a). Water quality has been improving for several of the parameters over the past seven years.

27 storm water ponds have been installed within the Bronson Creek watershed (CWS 2002). All of these facilities are adjacent to and upstream of the 3 sampling sites that are experiencing the most significant negative trends (improving water quality) within the watershed (Figure 20). This discovery is extremely interesting, but it is not known if the improving water quality at the 3 sampling sites has resulted from the installation of the stromwater facilities. This finding deserves additional investigation. 


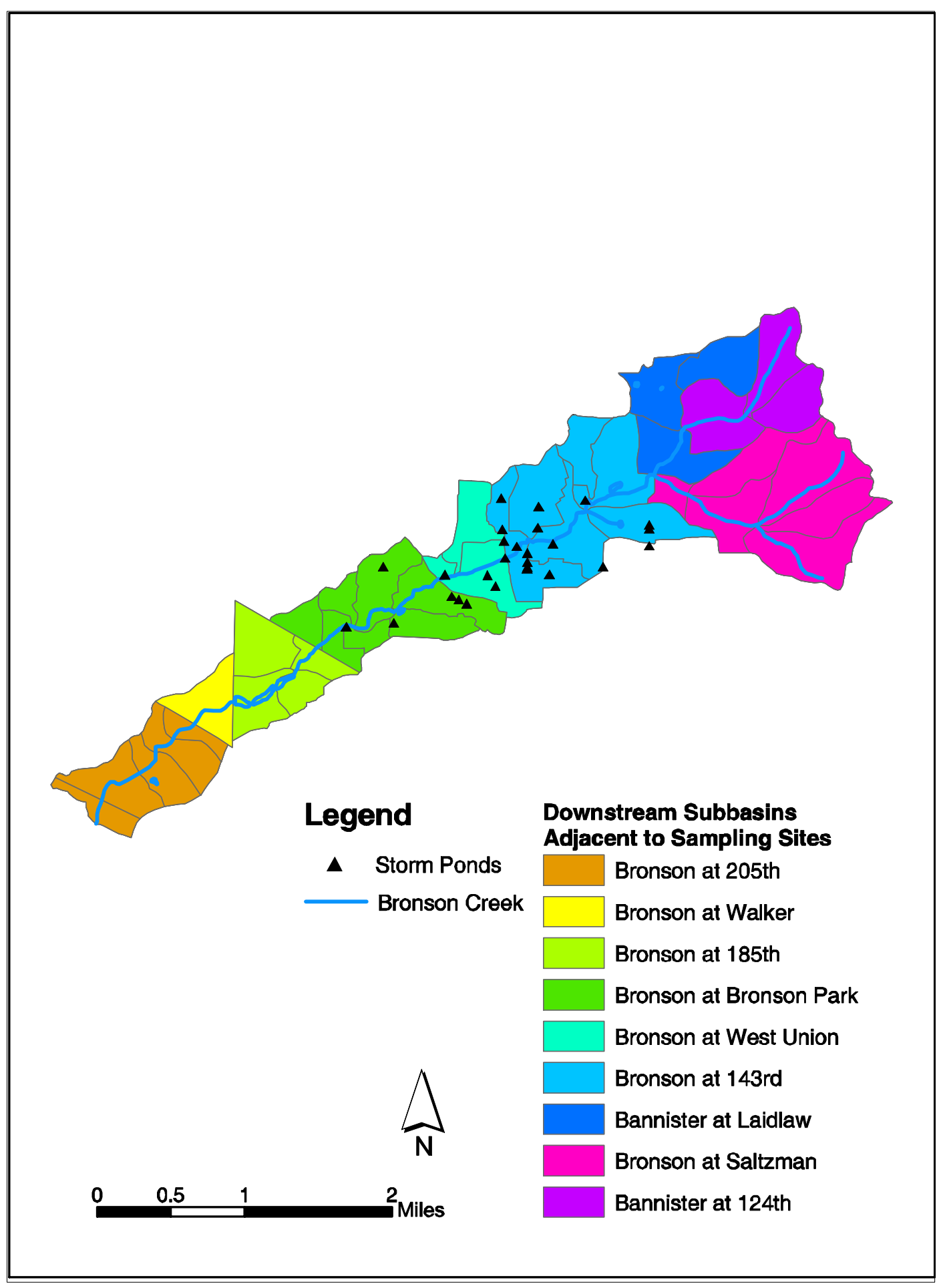

Figure 20 Stromwater facilities within Bronson Creek watershed 


\section{B. Value of Digitizing TIA}

Using land use classifications to estimate TIA values did not produce reliable results. The estimated TIA values were appreciably different from those produced by digitizing aerial photography. Large discrepancies were found between TIA percentages produced by the two methods in the heavily developed areas of the watershed. Areas in the middle of the watershed that were dominated by single family residential land use were underestimated. Mixed use areas in the lower watershed, in the Tannisborn shopping complex, were severely overestimated.

However, the land use estimates for 2001 took substantially less time and manpower to produce, partly because up to date land use data were readily available. It took a team of 2 to 3 digitizers approximately 1 week to digitize all impervious features within the watershed from the 2001 imagery. It only took a student one day to estimate TIA values from the 2001 RLIS GIS land use data.

The failure of the land use estimation procedure to produce dependable results does not necessarily preclude this technique from future use, but rather that the input coefficients for the TR-55 model are not accurate for Bronson Creek. Published values from other literature may have produced more accurate results for the Bronson Creek watershed. The Stormwater Manager's Resource Center (2003) has catalogued a number of impervious cover values from various models that could be used instead of the TR-55 values. It may also be possible to adjust estimation coefficients to match the output with 
the digitized values. A representative subset of a watershed could be digitized and used to calibrate this procedure. This would most likely produce coefficients that are applicable for specific development practices within a small watershed or larger region.

Due to the fact that the estimation procedure can produce inaccurate results, users of this type of data should be aware of its limitations. The ease of the technique, especially when land use data are available, makes it attractive to many management agencies when TIA values are needed for making management decisions or for modeling purposes.

\section{Recommendations for the future}

The data that has been collected within Bronson Creek provides a look at the water quality of an urbanizing watershed and holds many opportunities for future study. This project has taken a first look at urbanization and its effect on water quality with surprising results. As the watershed continues to develop, the water quality sampling regimen should continue to be maintained to allow for future analysis. The function and success of BMPs such as the installation of stormwater ponds deserves addition study. Preliminary analysis of trend results suggest that storm water ponds may have played a roll in the reduction of key water quality parameters such as TSS and phosphorous.

The addition of a new sampling site on the mainstem of Bronson Creek upstream of the Saltzman site (RM 5.6) would be extremely beneficial. This would allow the impact of development in the headwaters area to be monitored or investigated. At this time the 
upstream subbasins are only slightly developed and have TIA values less than $8.2 \%$, with the majority of the subbasin having TIA levels less than $4 \%$.

Finally, it is recommended that the total impervious area statistics continue to be digitized within Bronson Creek watershed and that yearly GIS layers are updated. Yearly updates are not time intensive because only new development needs to be added to the prior year's data layer. 


\section{References}

Alley, W.A., and Veenhuis, J.E., 1983. Effective impervious area in urban runoff modeling. Journal of Hydraulic Engineering, ASCE, 109(2): 313-319.

Arnold, C. L. and C. J. Gibbons. 1996. Impervious Surface Coverage: The emergence of a key environmental indicator. Journal of the American Planning Association 62(2): 243258.

Aroner, E.R. 2001. Tualatin River Basin Tributary Water Quality Status Report, 2001.

Report prepared for the Unified Sewerage Agency (now CWS) of Washington County by WQHYDRO. Portland, OR.

Booth D.B. 1991. Urbanization and the Natural Drainage System-Impacts, Solutions, and Prognosis. The Northwest Environmental Journal 7:93-118.

Clean Water Services (CWS). 2001a. Nonpoint Source Program for Total Maximaum Daily Load Requirements. January 2001.

Clean Water Services (CWS). 2001b. Stormwater Annual Report. August 2001.

Clean Water Services (CWS). 2002. Stormwater Ponds shapefile.

Clean Water Services (CWS). 2003. Clean Water Services Home Page. URL: http://www.cleanwaterservices.org/. Viewed April 14, 2003.

Hawksworth, J.T. 2001. Middle Tualatin-Rock Creek Watershed Analysis. U.S. Department of the Interior, Bureau of Land Management, Salem District Office, Tillamook Resource Area. Salem, Oregon

Helsel D.R. and R.M. Hirsch. 2002. Statistical Methods in Water Resources. Techniques of Water-Resources Investigations of the United States Geological Survey, US Geological Survey_TWRI Book 4, Chapter A3. 2002.

Klein, R. D. 1979. Urbanization and Stream Quality Impairment. Water Resources Bulletin. 15(4): 948-963.

Koski, M., C. Novak, et al. 2001. Unit Boundary Database Attribute Standards -Draft. Bureau of Land Management. URL:

http://www.reo.gov/gis/projects/watersheds/Data_Standards2.htm, Viewed April 28, 2003.

Leopold, L.B. 1968. Hydrology for Urban Land Planning - A Guidebook of the Hydrologic Effects of Urban Land Use. USGS Circular 554. 
Metro. 2001. Portland Oregon Metropolitan Regional Land Information System (RLIS) Digital Data.

Metro. 2003. Portland Oregon Metropolitan Regional Land Information System (RLIS) RLIS Metadata Viewer, Portland, Oregon, http://www.metroregion.org/article.cfm?articleid=1024, Viewed January 23, 2003.

Natural Resources Conservation Service (NRCS). 1996. Urban Hydrology for Small Watersheds TR-55. Natural Resources Conservation Service, US Department of Agriculture, Washington, DC.

Oregon Department of Environmental Quality (ODEQ). 2001. Tualatin Subbasin Total Maximum Daily Load (TMDL). ODEQ Water Quality Division. Portland, OR.

Regional Ecosystem Office (REO). 2003a. Fifth and Sixth Field Watersheds. Bureau of Land Management, Regional Ecosystem Office. URL:

http://www.reo.gov/gis/projects/watersheds/, Viewed April 28, 2003.

Regional Ecosystem Office (REO). 2003b. Version 1.3 Sixth Filed Watersheds Digital Coverages.

Schuler, T.R and H.K. Holland (Eds.). 2000a. Impact of Suspended and Deposited Sediment. Watershed Protection Techniques. Article 14.

Schuler, T.R and H.K. Holland (Eds.). 2000b. The Importance of Imperviousness. Watershed Protection Techniques. 1(3): 100-111.

Sleavin, W., S. Prisloe, L. Giannotti, J. Stocker, D.L. Civco. 2000. Measuring Impervious Surfaces for Non-point Source Pollution Modeling. Proc. 2000 ASPRS Annual Convention, Washington, D.C. 11 p.

Stormwater Manager's Resource Center. 2003. The Simple Method. URL: http://www.stormwatercenter.net/. Viewed May 28, 2003.

Sutherland, R.C. 2000. Methods for Measuring the Effective Impervious Area of Urban Watersheds. In T.R. Schueler, and H.K. Holland. The Practice of Watershed Protection. Center for Watershed Protection, Ellicott City, MD

U.S. Environmental Protection Agency (USEPA). 1997. Urbanization and Streams: Studies of Hydrologic Impacts. EPA841-R-97-009. U.S. Environmental Protection Agency, Office of Water, Washington, DC.

U.S. Environmental Protection Agency (USEPA). 2002. National Management Measures Guidance to Control Nonpoint Source Pollution from Urban Areas- DRAFT. 
EPA 842-B-02-003 U.S. Environmental Protection Agency, Office of Wetlands, Oceans, and Watersheds, Washington, DC.

US Geological Survey (USGS). 1997. Relations of the Tualatin River Water Temperatures to Natural and Human-caused Factors. Water-Resources Investigations Report 97-4071. US Geological Survey, US Department of Interior, Reston, VA.

Weintz D.A. et al. 1998. Water Quality in the Willamette Basin, Oregon, 1991-95. U.S. Geological Survey Circular 1161. US Geological Survey, US Department of Interior, Reston, VA.

Zielinski.J. 2002. Watershed Vulnerability Analysis. Center for Watershed Protection, Ellicott City, MD. 


\section{APPENDICES}




\section{Appendix A: SPSS ANOVA Output for Monthly Analysis}

Output of ANOVA Tukey analysis on ranks for the appropriate season for each water quality variable. All water quality variables failed the null hypothesis that the population means for all months were the same.

\section{Ammonia}

RANK of AMMONIA

\begin{tabular}{|c|c|c|c|c|c|}
\hline & $\begin{array}{c}\text { Sum of } \\
\text { Squares }\end{array}$ & df & Mean Square & F & Sig. \\
\hline $\begin{array}{c}\text { Between } \\
\text { Groups }\end{array}$ & 14577409.609 & 11 & 1325219.055 & 6.615 & .000 \\
\hline Within Groups & 314950826.003 & 1572 & 200350.398 & & \\
\hline Total & 329528235.612 & 1583 & & & \\
\hline
\end{tabular}

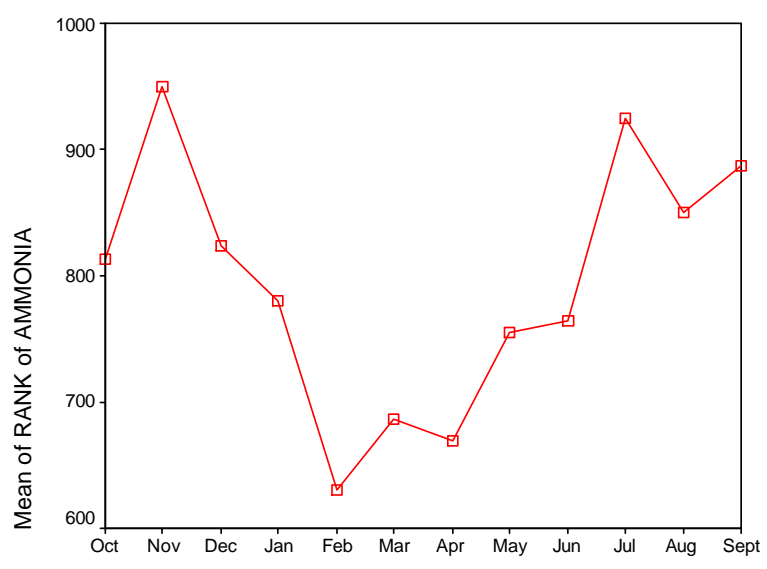

Water Year Month

RANK of AMMONIA

Tukey HSD ${ }^{a, b}$

\begin{tabular}{|l|r|r|c|c|c|}
\hline \multirow{2}{*}{ Water Year Month } & & \multicolumn{4}{|c|}{ Subset for alpha $=.05$} \\
\cline { 3 - 6 } & $\mathrm{N}$ & 1 & 2 & 3 & \multicolumn{1}{c|}{4} \\
\hline Feb & 136 & 630.283 & & & \\
Mar & 112 & 669.509 & 669.509 & & \\
May & 151 & 685.821 & 685.821 & & \\
Jun & 135 & 754.533 & 754.533 & 754.533 & \\
Jan & 147 & 764.483 & 764.483 & 764.483 & \\
Oct & 127 & 780.094 & 780.094 & 780.094 & 780.094 \\
Dec & 134 & & 812.896 & 812.896 & 812.896 \\
Aug & 104 & & 823.385 & 823.385 & 823.385 \\
Sept & 151 & & 850.228 & 850.228 & 850.228 \\
Jul & 121 & & & 887.256 & 887.256 \\
Nov & 145 & & & 924.486 & 924.486 \\
Sig. & 121 & & & & 949.628 \\
\hline
\end{tabular}

Means for groups in homogeneous subsets are displayed.

a. Uses Harmonic Mean Sample Size = 130.273.

b. The group sizes are unequal. The harmonic mean of the group sizes is used. Type I error levels are not guaranteed. 


\section{E. COLI}

RANK of EC

\begin{tabular}{|c|c|c|c|c|c|}
\hline & $\begin{array}{c}\text { Sum of } \\
\text { Squares }\end{array}$ & df & Mean Square & F & Sig. \\
\hline $\begin{array}{c}\text { Between } \\
\text { Groups }\end{array}$ & 18040306.171 & 11 & 1640027.834 & 12.555 & .000 \\
\hline Within Groups & 169685211.329 & 1299 & 130627.568 & & \\
\hline Total & 187725517.500 & 1310 & & & \\
\hline
\end{tabular}

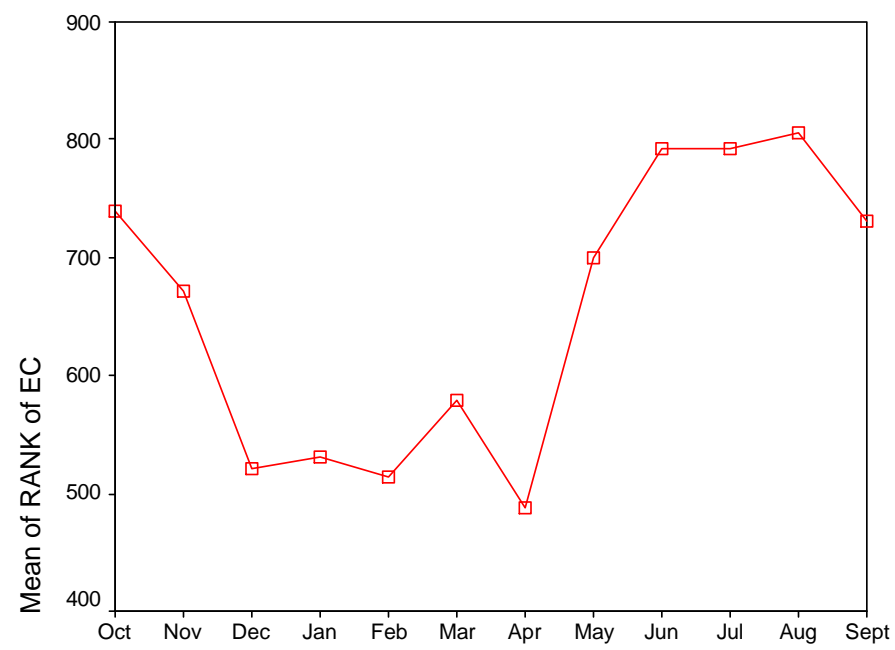

Water Year Month

RANK of EC

Tukey HSD ${ }^{a, b}$

\begin{tabular}{|l|r|r|r|r|r|}
\hline \multirow{2}{*}{ Water Year Month } & & \multicolumn{4}{|c|}{ Subset for alpha $=.05$} \\
\cline { 3 - 6 } & $\mathrm{N}$ & 1 & 2 & 3 & 4 \\
\hline Apr & 120 & 488.454 & & & \\
Feb & 109 & 514.725 & 514.725 & & \\
Jec & 88 & 520.574 & 520.574 & & \\
Man & 109 & 530.174 & 530.174 & & \\
Nov & 128 & 578.633 & 578.633 & 578.633 & \\
May & 94 & & 671.617 & 671.617 & 671.617 \\
Sept & 131 & & & 699.595 & 699.595 \\
Oct & 87 & & & 730.851 & 730.851 \\
Jul & 91 & & & 740.198 & 740.198 \\
Jun & 126 & & & & 792.056 \\
Aug & 122 & & & & 793.102 \\
Sig. & 106 & & & & 805.222 \\
& & .804 & .067 & .051 & .226 \\
\hline
\end{tabular}

Means for groups in homogeneous subsets are displayed.

a. Uses Harmonic Mean Sample Size $=106.971$.

b. The group sizes are unequal. The harmonic mean of the group sizes is used. Type I error levels are not guaranteed. 


\section{FECAL COLIFORM}

RANK of FC

\begin{tabular}{|c|c|c|c|c|c|}
\hline & $\begin{array}{c}\text { Sum of } \\
\text { Squares }\end{array}$ & df & Mean Square & F & Sig. \\
\hline $\begin{array}{c}\text { Between } \\
\text { Groups }\end{array}$ & 674600.199 & 11 & 61327.291 & 5.830 & .000 \\
\hline Within Groups & 3860562.801 & 367 & 10519.245 & & \\
\hline Total & 4535163.000 & 378 & & & \\
\hline
\end{tabular}

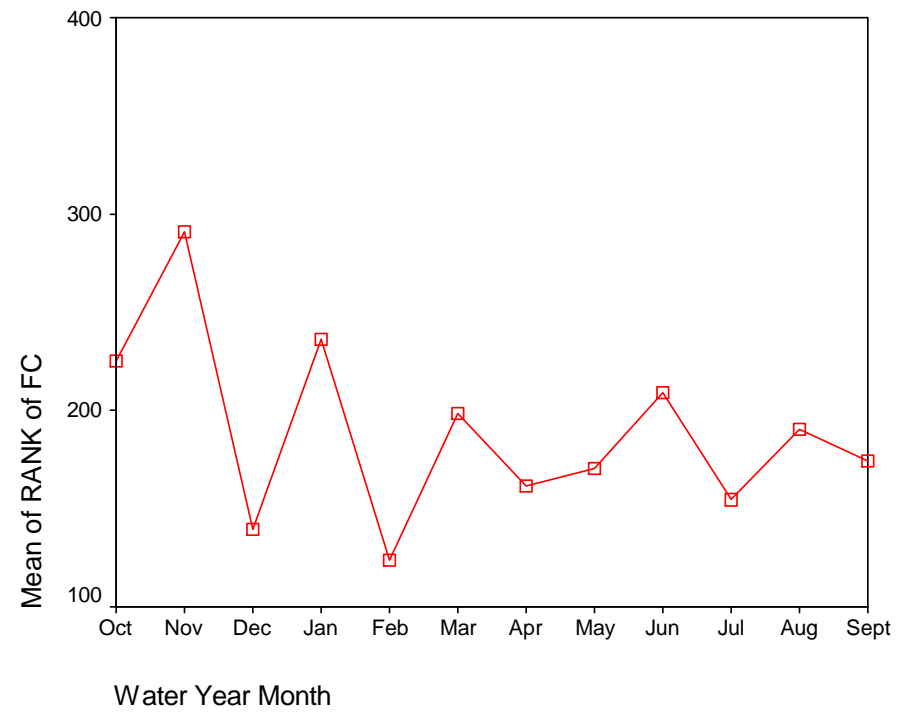

RANK of FC

Tukey HSD ${ }^{\mathrm{a}, \mathrm{b}}$
\begin{tabular}{|l|r|r|r|r|r|}
\hline \multirow{3}{*}{ Water Year Month } & $\mathrm{N}$ & \multicolumn{4}{|c|}{ Subset for alpha $=.05$} \\
\hline Feb & 30 & 124.300 & 2 & 3 & 4 \\
Dec & 18 & 139.778 & 139.778 & & \\
Jul & 31 & 154.468 & 154.468 & 154.468 & \\
Apr & 33 & 161.576 & 161.576 & 161.576 & \\
May & 35 & 170.229 & 170.229 & 170.229 & \\
Sept & 32 & 174.125 & 174.125 & 174.125 & \\
Aug & 43 & 190.733 & 190.733 & 190.733 & \\
Mar & 45 & 198.222 & 198.222 & 198.222 & \\
Jun & 32 & 209.172 & 209.172 & 209.172 & 209.172 \\
Oct & 28 & & 225.339 & 225.339 & 225.339 \\
Jan & 21 & & & 236.405 & 236.405 \\
Nov & 31 & & & & 291.145 \\
Sig. & & .067 & .062 & .091 & .091 \\
\hline
\end{tabular}

Means for groups in homogeneous subsets are displayed.

a. Uses Harmonic Mean Sample Size $=29.733$.

b. The group sizes are unequal. The harmonic mean of the group sizes is used. Type I error levels are not guaranteed. 


\section{NITROGEN}

RANK of NITROGEN

\begin{tabular}{|c|c|c|c|c|c|}
\hline & Sum of Squares & df & Mean Square & F & Sig. \\
\hline Between Groups & 166429787.259 & 11 & 15129980.660 & 140.608 & .000 \\
\hline Within Groups & 170014768.034 & 1580 & 107604.284 & & \\
\hline Total & 336444555.293 & 1591 & & & \\
\hline
\end{tabular}

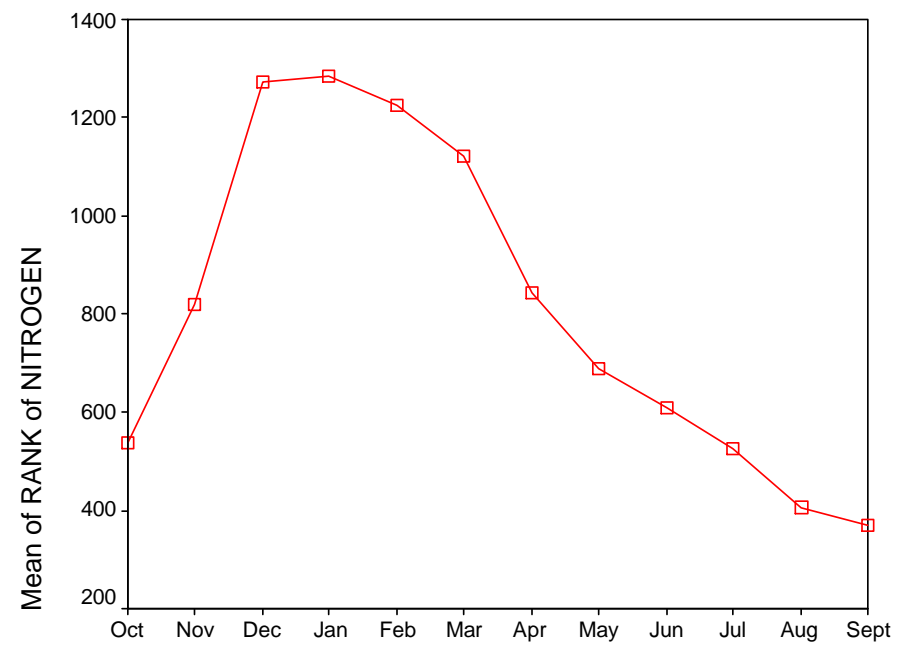

Water Year Month

RANK of NITROGEN

Tukey HSD ${ }^{\mathrm{a}, \mathrm{b}}$

\begin{tabular}{|c|c|c|c|c|c|c|c|c|c|}
\hline \multirow[b]{2}{*}{ Water Year Month } & \multirow[b]{2}{*}{$\mathrm{N}$} & \multicolumn{8}{|c|}{ Subset for alpha $=.05$} \\
\hline & & 1 & 2 & 3 & 4 & 5 & 6 & 7 & 8 \\
\hline Sept & 121 & 369.562 & & & & & & & \\
\hline Aug & 151 & 405.974 & 405.974 & & & & & & \\
\hline Jul & 145 & & 525.348 & 525.348 & & & & & \\
\hline Oct & 134 & & 536.716 & 536.716 & & & & & \\
\hline Jun & 147 & & & 609.466 & 609.466 & & & & \\
\hline May & 135 & & & & 689.441 & 689.441 & & & \\
\hline Nov & 121 & & & & & 818.719 & 818.719 & & \\
\hline Apr & 120 & & & & & & 842.488 & & \\
\hline Mar & 151 & & & & & & & 1119.911 & \\
\hline Feb & 136 & & & & & & & 1224.316 & 1224.316 \\
\hline Dec & 104 & & & & & & & & 1271.284 \\
\hline Jan & 127 & & & & & & & & 1286.630 \\
\hline Sig. & & .999 & .057 & .640 & .711 & .064 & 1.000 & .294 & .930 \\
\hline
\end{tabular}

Means for groups in homogeneous subsets are displayed.

a. Uses Harmonic Mean Sample Size $=131.120$.

b. The group sizes are unequal. The harmonic mean of the group sizes is used. Type I error levels are not guaranteed. 
ORTHO-PHOSPHATE

RANK of OP

\begin{tabular}{|c|c|c|c|c|c|}
\hline & $\begin{array}{c}\text { Sum of } \\
\text { Squares }\end{array}$ & df & Mean Square & F & Sig. \\
\hline $\begin{array}{c}\text { Between } \\
\text { Groups }\end{array}$ & 71643821.528 & 11 & 6513074.684 & 38.499 & .000 \\
\hline Within Groups & 268145103.234 & 1585 & 169176.721 & & \\
\hline Total & 339788924.763 & 1596 & & & \\
\hline
\end{tabular}

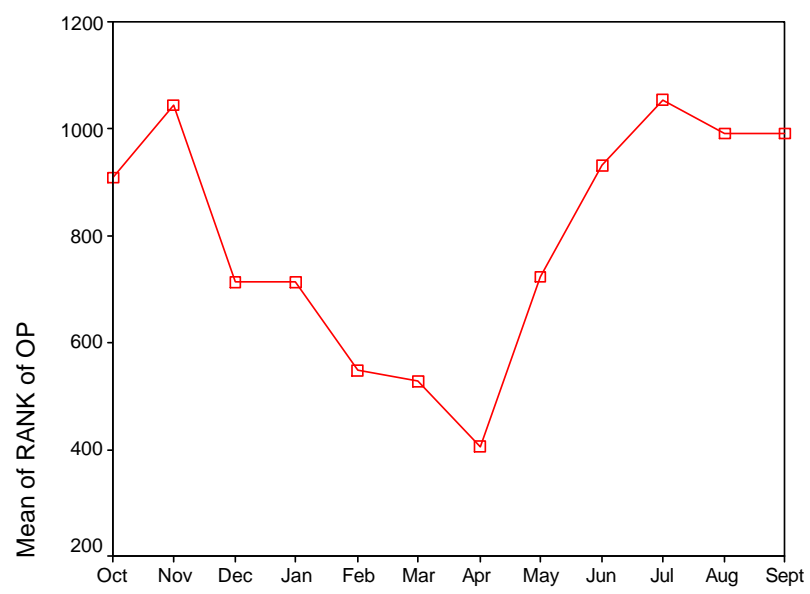

Water Year Month

RANK of OP

Tukey $\mathrm{HSD}^{\mathrm{a}, \mathrm{b}}$

\begin{tabular}{|l|r|r|c|c|c|}
\hline \multirow{2}{*}{ Water Year Month } & & \multicolumn{4}{|c|}{ Subset for alpha $=.05$} \\
\cline { 3 - 6 } & $\mathrm{N}$ & 1 & 2 & 3 & 4 \\
\hline Apr & 120 & 406.871 & & & \\
Feb & 151 & 528.060 & & & \\
Jan & 136 & 547.088 & 547.088 & & \\
Dec & 127 & & 711.594 & 711.594 & \\
May & 104 & & & 713.601 & \\
Oct & 140 & & & 724.032 & \\
Jun & 134 & & & & 908.657 \\
Sept & 147 & & & & 931.048 \\
Aug & 121 & & & & 991.289 \\
Nov & 151 & & & & 992.808 \\
Jul & 121 & & & & 1043.211 \\
Sig. & 145 & & & & 1053.948 \\
\hline
\end{tabular}

Means for groups in homogeneous subsets are displayed.

a. Uses Harmonic Mean Sample Size $=131.500$.

b. The group sizes are unequal. The harmonic mean of the group sizes is used. Type I error levels are not guaranteed. 


\section{TEMPERATURE}

RANK of TEMP

\begin{tabular}{|c|c|c|c|c|c|}
\hline & $\begin{array}{c}\text { Sum of } \\
\text { Squares }\end{array}$ & df & Mean Square & F & Sig. \\
\hline $\begin{array}{c}\text { Between } \\
\text { Groups }\end{array}$ & 239175308.683 & 11 & 21743209.880 & 491.239 & .000 \\
\hline Within Groups & 67809317.650 & 1532 & 44261.957 & & \\
\hline Total & 306984626.334 & 1543 & & & \\
\hline
\end{tabular}

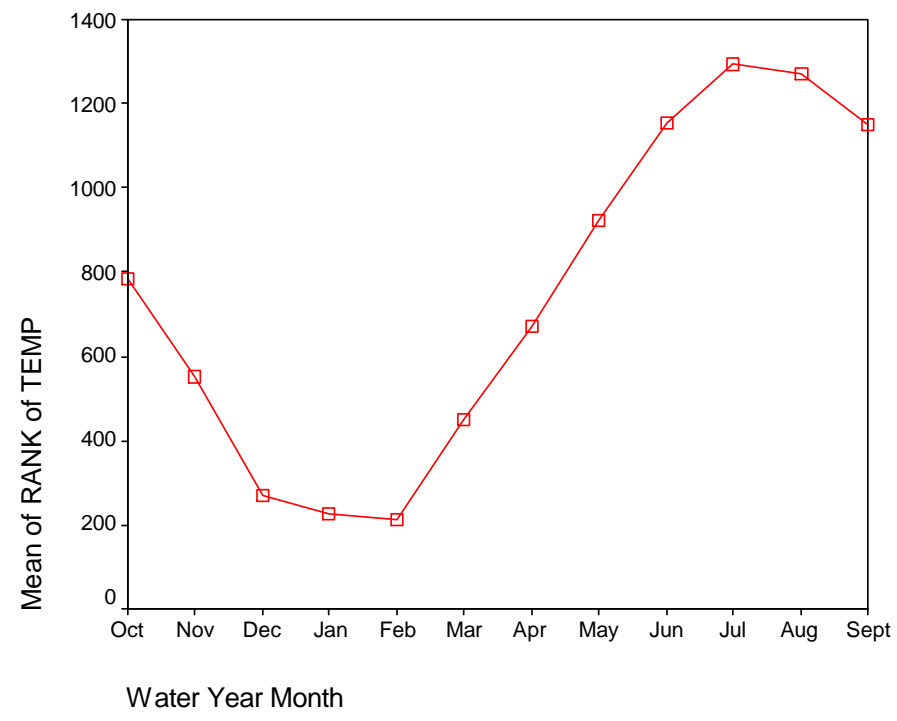

RANK of TEMP

Tukey HSD ${ }^{\mathrm{a}, \mathrm{b}}$

\begin{tabular}{|c|c|c|c|c|c|c|c|c|c|}
\hline \multirow[b]{2}{*}{ Water Year Month } & \multirow[b]{2}{*}{$\mathrm{N}$} & \multicolumn{8}{|c|}{ Subset for alpha $=.05$} \\
\hline & & 1 & 2 & 3 & 4 & 5 & 6 & 7 & 8 \\
\hline Feb & 132 & 214.348 & & & & & & & \\
\hline Jan & 117 & 228.893 & & & & & & & \\
\hline Dec & 104 & 268.303 & & & & & & & \\
\hline Mar & 133 & & 450.023 & & & & & & \\
\hline Nov & 110 & & & 550.273 & & & & & \\
\hline Apr & 121 & & & & 670.368 & & & & \\
\hline Oct & 132 & & & & & 784.936 & & & \\
\hline May & 140 & & & & & & 921.061 & & \\
\hline Sept & 121 & & & & & & & 1150.355 & \\
\hline Jun & 147 & & & & & & & 1156.316 & \\
\hline Aug & 151 & & & & & & & & 1271.887 \\
\hline Jul & 136 & & & & & & & & 1292.801 \\
\hline Sig. & & .662 & 1.000 & 1.000 & 1.000 & 1.000 & 1.000 & 1.000 & 1.000 \\
\hline
\end{tabular}

Means for groups in homogeneous subsets are displayed.

a. Uses Harmonic Mean Sample Size $=127.154$.

b. The group sizes are unequal. The harmonic mean of the group sizes is used. Type I error levels are not guaranteed. 


\section{TOTAL PHOSPHOROUS}

RANK of TP

\begin{tabular}{|c|c|c|c|c|c|}
\hline & $\begin{array}{c}\text { Sum of } \\
\text { Squares }\end{array}$ & df & Mean Square & F & Sig. \\
\hline $\begin{array}{c}\text { Between } \\
\text { Groups }\end{array}$ & 31884236.381 & 11 & 2898566.944 & 15.001 & .000 \\
\hline Within Groups & 305483411.051 & 1581 & 193221.639 & & \\
\hline Total & 337367647.433 & 1592 & & & \\
\hline
\end{tabular}

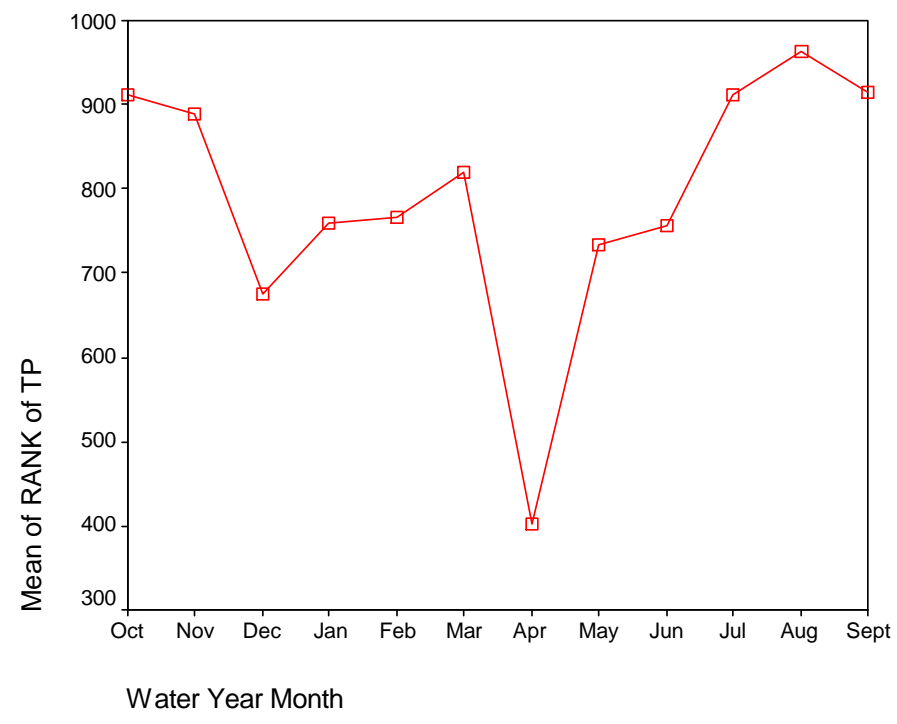

RANK of TP

Tukey $\mathrm{HSD}^{\mathrm{a}, \mathrm{b}}$

\begin{tabular}{|c|c|c|c|c|c|c|}
\hline \multirow[b]{2}{*}{ Water Year Month } & \multirow[b]{2}{*}{$\mathrm{N}$} & \multicolumn{5}{|c|}{ Subset for alpha $=.05$} \\
\hline & & 1 & 2 & 3 & 4 & 5 \\
\hline Apr & 120 & 402.967 & & & & \\
\hline Dec & 104 & & 676.034 & & & \\
\hline May & 140 & & 732.318 & 732.318 & & \\
\hline Jun & 147 & & 756.139 & 756.139 & 756.139 & \\
\hline Jan & 127 & & 758.929 & 758.929 & 758.929 & \\
\hline Feb & 136 & & 765.051 & 765.051 & 765.051 & \\
\hline Mar & 151 & & 818.245 & 818.245 & 818.245 & 818.245 \\
\hline Nov & 121 & & & 888.178 & 888.178 & 888.178 \\
\hline Oct & 134 & & & & 911.280 & 911.280 \\
\hline Jul & 141 & & & & 912.695 & 912.695 \\
\hline Sept & 121 & & & & 914.165 & 914.165 \\
\hline Aug & 151 & & & & & 963.881 \\
\hline Sig. & & 1.000 & .269 & .152 & .138 & .235 \\
\hline
\end{tabular}

Means for groups in homogeneous subsets are displayed.

a. Uses Harmonic Mean Sample Size = 131.219.

b. The group sizes are unequal. The harmonic mean of the group sizes is used. Type I error levels are not guaranteed. 


\section{TOTAL SUSPENDED SOLIDS}

RANK of TSS

\begin{tabular}{|r|rr|r|r|r|}
\hline & $\begin{array}{r}\text { Sum of } \\
\text { Squares }\end{array}$ & $\mathrm{df}$ & Mean Square & $\mathrm{F}$ & Sig. \\
\hline $\begin{array}{r}\text { Between } \\
\text { Groups }\end{array}$ & 18967912.450 & 11 & 1724355.677 & 8.576 & .000 \\
\hline Within Groups & 317691122.368 & 1580 & 201070.331 & & \\
\hline Total & 336659034.818 & 1591 & & & \\
\hline
\end{tabular}

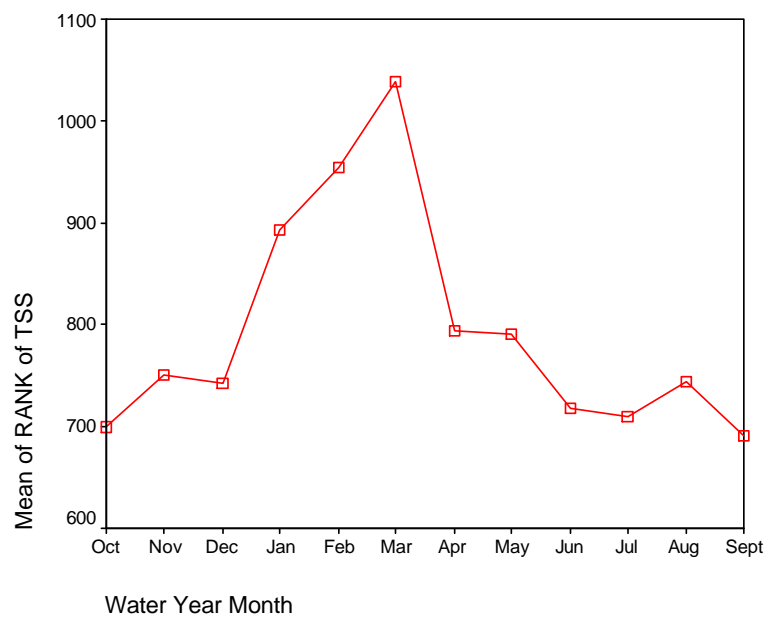

RANK of TSS

Tukey HSD ${ }^{\mathrm{a}, \mathrm{b}}$

\begin{tabular}{|l|r|r|r|r|r|}
\hline \multirow{2}{*}{ Water Year Month } & & \multicolumn{4}{|c|}{ Subset for alpha $=.05$} \\
\cline { 3 - 6 } & $\mathrm{N}$ & 1 & 2 & 3 & \multicolumn{1}{|c|}{4} \\
\hline Sept & 116 & 691.375 & & & \\
Jul & 134 & 699.172 & & & \\
Jun & 145 & 709.355 & & & \\
Dec & 147 & 718.000 & 718.000 & & \\
Aug & 104 & 743.000 & 743.000 & & \\
Nov & 151 & 743.709 & 743.709 & & \\
May & 121 & 750.045 & 750.045 & & \\
Apr & 140 & 790.375 & 790.375 & 790.375 & \\
Jan & 120 & 793.046 & 793.046 & 793.046 & \\
Feb & 127 & & 892.469 & 892.469 & 892.469 \\
Mar & 136 & & & 954.618 & 954.618 \\
Sig. & 151 & & & & 1038.642 \\
& & .799 & .072 & .120 & .259 \\
\hline
\end{tabular}

Means for groups in homogeneous subsets are displayed.

a. Uses Harmonic Mean Sample Size $=130.989$.

b. The group sizes are unequal. The harmonic mean of the group sizes is used. Type I error levels are not guaranteed. 


\section{Appendix B: SPSS ANOVA Output for Downstream Analysis}

Output of ANOVA Tukey analysis on ranks for the appropriate season for each water quality variable. All water quality variables failed the null hypothesis that the population means for all sampling sites were the same.

\section{TEMPERATURE}

RANK of TEMP

\begin{tabular}{|c|c|c|c|c|c|c|}
\hline \multicolumn{2}{|c|}{} & $\begin{array}{c}\text { Sum of } \\
\text { Squares }\end{array}$ & df & Mean Square & F & Sig. \\
\hline \multicolumn{2}{|c|}{ Between Groups } & 6336622.721 & 8 & 792077.840 & 76.573 .000 \\
\hline \multicolumn{2}{|c|}{ Within Groups } & 2875668.557 & 278 & 10344.132 & & \\
\hline Total & 9212291.279 & & & & & \\
\hline
\end{tabular}

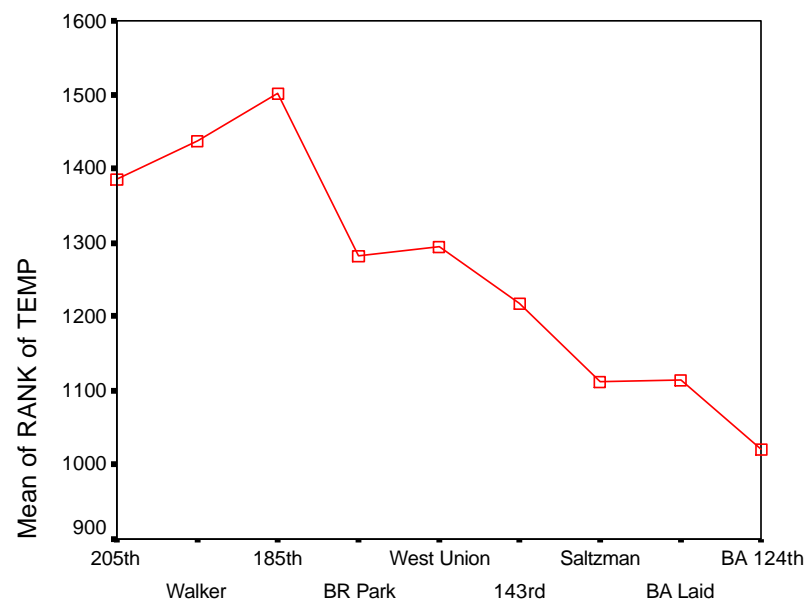

Site number

\begin{tabular}{|c|c|c|c|c|c|c|}
\hline & N & $\begin{array}{c}\text { Subset for } \\
\text { alpha } \\
.05\end{array}$ & & & & \\
\hline $\begin{array}{c}\text { Site } \\
\text { number }\end{array}$ & & 1 & 2 & 3 & 4 & 5 \\
\hline BA 124th & 21 & 1020.167 & & & & \\
\hline Saltzman & 30 & & 1111.933 & & & \\
\hline BA Laid & 30 & & 1115.183 & & & \\
\hline 143rd & 34 & & & 1218.529 & & \\
\hline BR Park & 35 & & & 1281.486 & & \\
\hline $\begin{array}{c}\text { West } \\
\text { Union }\end{array}$ & 30 & & & 1295.183 & & \\
\hline 205th & 34 & & & & 1384.441 & \\
\hline Walker & 34 & & & & 1438.529 & 1438.529 \\
\hline 185th & 39 & & & & & 1500.526 \\
\hline Sig. & & 1.000 & 1.000 & .078 & .479 & .288 \\
\hline
\end{tabular}

RANK of TEMP

Tukey HSD

Means for groups in homogeneous subsets are displayed.

a Uses Harmonic Mean Sample Size $=31.027$.

b The group sizes are unequal. The harmonic mean of the group sizes is used. Type I error levels are not guaranteed. 


\section{TOTAL PHOSPHOROUS}

RANK of TP

\begin{tabular}{|c|c|c|c|c|c|}
\hline & $\begin{array}{c}\text { Sum of } \\
\text { Squares }\end{array}$ & df & Mean Square & F & Sig. \\
\hline $\begin{array}{c}\text { Between } \\
\text { Groups }\end{array}$ & 43063867.905 & 8 & 5382983.488 & 42.365 & .000 \\
\hline Within Groups & 68359295.719 & 538 & 127061.888 & & \\
\hline Total & 111423163.623 & 546 & & & \\
\hline
\end{tabular}

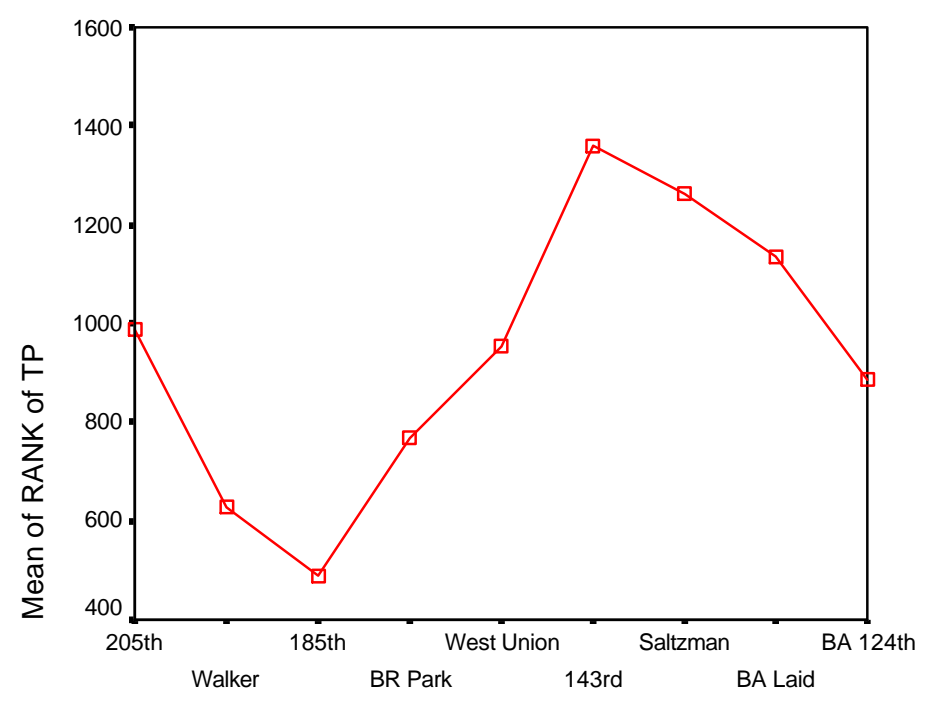

Site number

RANK of TP

Tukey HSD

\begin{tabular}{|c|c|c|c|c|c|c|c|c|}
\hline & N & $\begin{array}{c}\text { Subset for } \\
\text { alpha } \\
.05\end{array}$ & & & & & & \\
\hline $\begin{array}{c}\text { Site } \\
\text { number }\end{array}$ & & 1 & 2 & 3 & 4 & 5 & 6 & 7 \\
\hline 185th & 73 & 487.568 & & & & & & \\
\hline Walker & 67 & 629.993 & 629.993 & & & & & \\
\hline BR Park & 68 & & 768.456 & 768.456 & & & & \\
\hline BA 124th & 39 & & & 887.590 & 887.590 & & & \\
\hline $\begin{array}{c}\text { West } \\
\text { Union }\end{array}$ & 56 & & & 955.491 & 955.491 & 955.491 & & \\
\hline 205th & 68 & & & & 986.647 & 986.647 & & \\
\hline BA Laid & 55 & & & & & 1134.982 & 1134.982 & \\
\hline Saltzman & 55 & & & & & & 1262.745 & 1262.745 \\
\hline 143rd & 66 & & & & & & & 1360.818 \\
\hline Sig. & & .429 & .470 & .105 & .852 & .140 & .584 & .859 \\
\hline
\end{tabular}

Means for groups in homogeneous subsets are displayed.

a Uses Harmonic Mean Sample Size $=58.805$.

b The group sizes are unequal. The harmonic mean of the group sizes is used. Type I error levels are not guaranteed. 


\section{NITROGEN}

RANK of NITROGEN

\begin{tabular}{|c|c|c|c|c|c|}
\hline & $\begin{array}{c}\text { Sum of } \\
\text { Squares }\end{array}$ & df & Mean Square & F & Sig. \\
\hline $\begin{array}{c}\text { Between } \\
\text { Groups }\end{array}$ & 2279031.575 & 8 & 284878.947 & 5.741 & .000 \\
\hline Within Groups & 11066150.001 & 223 & 49623.991 & & \\
\hline Total & 13345181.577 & 231 & & & \\
\hline
\end{tabular}

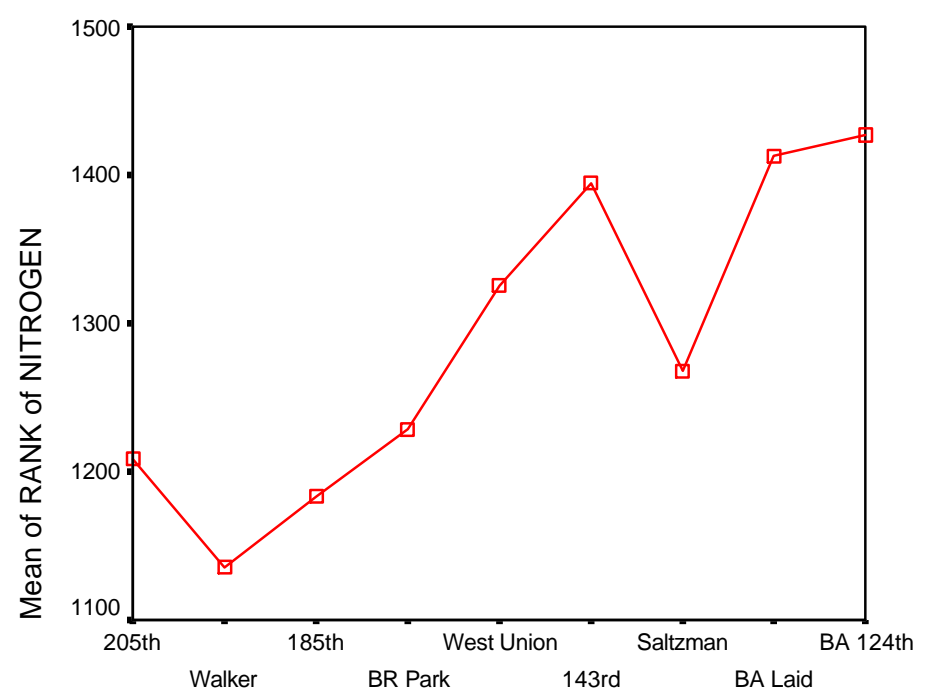

Site number

RANK of NITROGEN

Tukey HSD

\begin{tabular}{|c|c|c|c|c|c|}
\hline & N & $\begin{array}{c}\text { Subset for } \\
\text { alpha }= \\
.05\end{array}$ & & & \\
\hline $\begin{array}{c}\text { Site } \\
\text { number }\end{array}$ & & 1 & 2 & 3 & 4 \\
\hline Walker & 26 & 1135.577 & & & \\
\hline 185th & 30 & 1183.250 & & & \\
\hline 205th & 26 & 1208.673 & 1208.673 & & \\
\hline BR Park & 27 & 1228.833 & 1228.833 & 1228.833 & \\
\hline Saltzman & 26 & 1267.077 & 1267.077 & 1267.077 & 1267.077 \\
\hline $\begin{array}{c}\text { West } \\
\text { Union }\end{array}$ & 26 & 1324.654 & 1324.654 & 1324.654 & 1324.654 \\
\hline 143rd & 27 & & 1393.926 & 1393.926 & 1393.926 \\
\hline BA Laid & 26 & & & 1413.231 & 1413.231 \\
\hline BA 124th & 18 & & & & 1426.222 \\
\hline Sig. & & .068 & .081 & .084 & .218 \\
\hline
\end{tabular}

Means for groups in homogeneous subsets are displayed.

a Uses Harmonic Mean Sample Size $=25.333$.

b The group sizes are unequal. The harmonic mean of the group sizes is used. Type I error levels are not guaranteed. 


\section{AMMONIA}

RANK of AMMONIA

\begin{tabular}{|c|c|c|c|c|c|}
\hline & $\begin{array}{c}\text { Sum of } \\
\text { Squares }\end{array}$ & df & Mean Square & F & Sig. \\
\hline $\begin{array}{c}\text { Between } \\
\text { Groups }\end{array}$ & 64057727.182 & 8 & 8007215.898 & 70.345 & .000 \\
\hline Within Groups & 75467865.312 & 663 & 113827.851 & & \\
\hline Total & 139525592.494 & 671 & & & \\
\hline
\end{tabular}

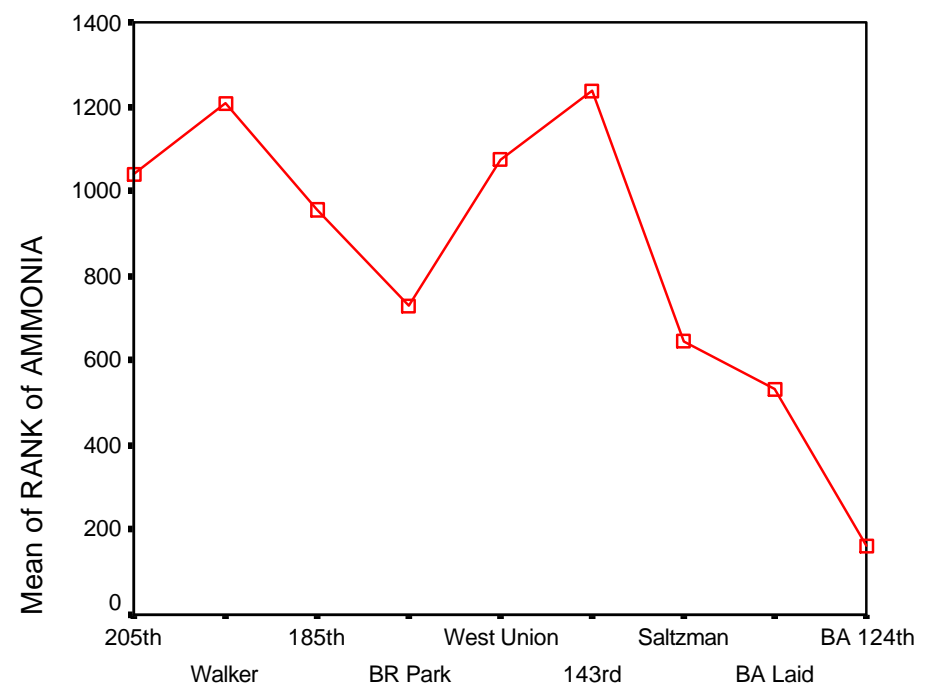

Site number

RANK of AMMONIA

Tukey HSD

\begin{tabular}{|c|c|c|c|c|c|c|c|}
\hline & N & $\begin{array}{c}\text { Subset for } \\
\text { alpha } \\
.05\end{array}$ & & & & & \\
\hline $\begin{array}{c}\text { Site } \\
\text { number }\end{array}$ & & 1 & 2 & 3 & 4 & 5 & 6 \\
\hline BA 124th & 50 & 165.080 & & & & & \\
\hline BA Laid & 68 & & 534.184 & & & & \\
\hline Saltzman & 68 & & 644.088 & 644.088 & & & \\
\hline BR Park & 83 & & & 730.669 & & & \\
\hline 185th & 88 & & & & 958.460 & & \\
\hline 205th & 83 & & & & 1040.602 & 1040.602 & \\
\hline $\begin{array}{c}\text { West } \\
\text { Union }\end{array}$ & 68 & & & & 1075.154 & 1075.154 & 1075.154 \\
\hline Walker & 82 & & & & & 1210.000 & 1210.000 \\
\hline 143rd & 82 & & & & & & 1238.524 \\
\hline Sig. & & 1.000 & .570 & .833 & .485 & .064 & .086 \\
\hline
\end{tabular}

Means for groups in homogeneous subsets are displayed.

a Uses Harmonic Mean Sample Size $=72.599$.

b The group sizes are unequal. The harmonic mean of the group sizes is used. Type I error levels are not guaranteed. 


\section{E. COLI}

RANK of EC

\begin{tabular}{|c|c|c|c|c|c|}
\hline & $\begin{array}{c}\text { Sum of } \\
\text { Squares }\end{array}$ & df & Mean Square & F & Sig. \\
\hline $\begin{array}{c}\text { Between } \\
\text { Groups }\end{array}$ & 14244399.837 & 8 & 1780549.980 & 21.363 & .000 \\
\hline Within Groups & 28754265.100 & 345 & 83345.696 & & \\
\hline Total & 42998664.938 & 353 & & & \\
\hline
\end{tabular}

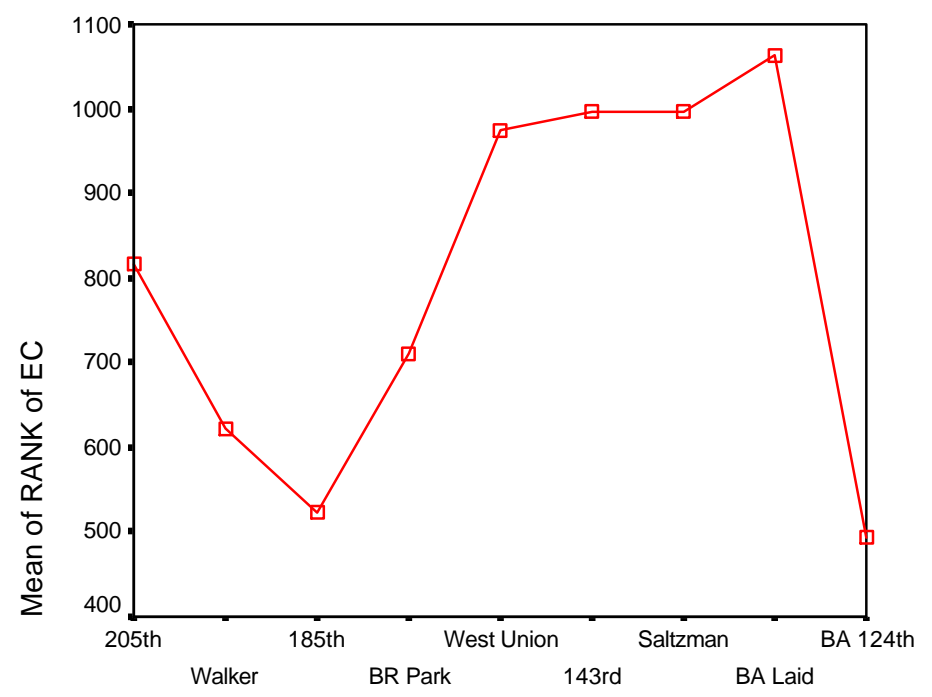

Site number

RANK of EC

Tukey HSD

\begin{tabular}{|c|c|c|c|c|c|c|}
\hline & $\mathrm{N}$ & $\begin{array}{c}\text { Subset for } \\
\text { alpha = } \\
.05\end{array}$ & & & & \\
\hline $\begin{array}{c}\text { Site } \\
\text { number }\end{array}$ & & 1 & 2 & 3 & 4 & 5 \\
\hline BA 124th & 25 & 494.860 & & & & \\
\hline 185th & 48 & 522.490 & 522.490 & & & \\
\hline Walker & 43 & 622.372 & 622.372 & 622.372 & & \\
\hline BR Park & 45 & & 709.456 & 709.456 & & \\
\hline 205th & 45 & & & 817.233 & 817.233 & \\
\hline $\begin{array}{l}\text { West } \\
\text { Union }\end{array}$ & 36 & & & & 974.708 & 974.708 \\
\hline 143rd & 43 & & & & 995.314 & 995.314 \\
\hline Saltzman & 33 & & & & 995.333 & 995.333 \\
\hline BA Laid & 36 & & & & & 1062.861 \\
\hline Sig. & & .599 & .114 & .084 & .157 & .922 \\
\hline
\end{tabular}

Means for groups in homogeneous subsets are displayed.

a Uses Harmonic Mean Sample Size $=37.871$.

b The group sizes are unequal. The harmonic mean of the group sizes is used. Type I error levels are not guaranteed. 


\section{ORTHO-PHOSPHATE}

RANK of OP

\begin{tabular}{|c|c|c|c|c|c|}
\hline & $\begin{array}{c}\text { Sum of } \\
\text { Squares }\end{array}$ & df & Mean Square & F & Sig. \\
\hline $\begin{array}{c}\text { Between } \\
\text { Groups }\end{array}$ & 78518771.494 & 8 & 9814846.437 & 79.153 & .000 \\
\hline Within Groups & 100439079.505 & 810 & 123998.864 & & \\
\hline Total & 178957850.999 & 818 & & & \\
\hline
\end{tabular}

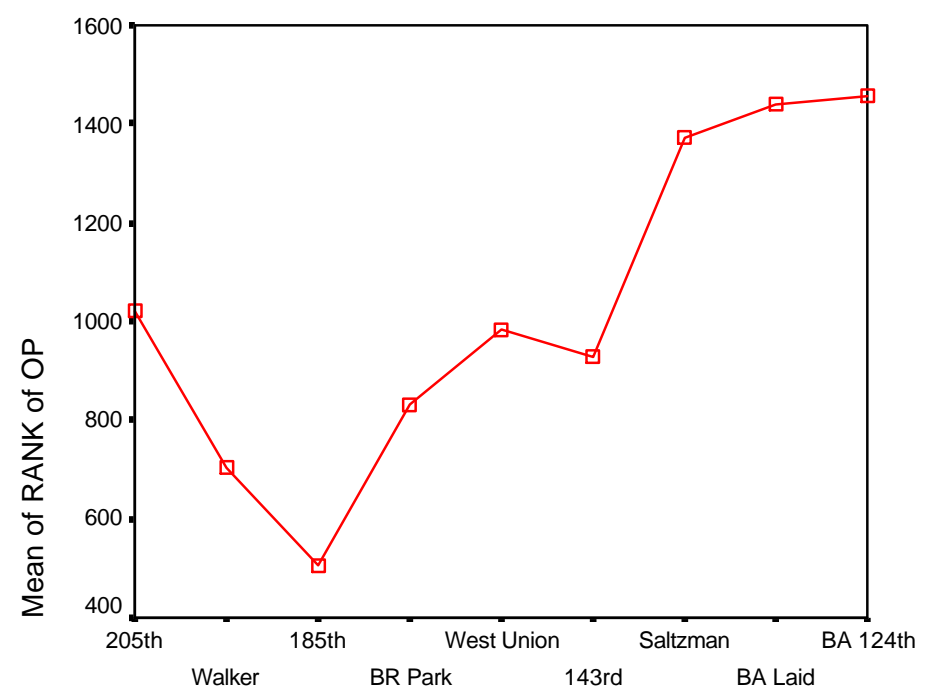

Site number

RANK of OP

Tukey HSD

\begin{tabular}{|c|c|c|c|c|c|c|}
\hline & N & $\begin{array}{c}\text { Subset for } \\
\text { alpha }= \\
.05\end{array}$ & & & & \\
\hline $\begin{array}{c}\text { Site } \\
\text { number }\end{array}$ & & 1 & 2 & 3 & 4 & 5 \\
\hline 185th & 108 & 506.296 & & & & \\
\hline Walker & 100 & & 705.560 & & & \\
\hline BR Park & 101 & & 829.658 & 829.658 & & \\
\hline 143rd & 99 & & & 928.040 & 928.040 & \\
\hline $\begin{array}{c}\text { West } \\
\text { Union }\end{array}$ & 84 & & & 983.554 & 983.554 & \\
\hline 205th & 101 & & & & 1020.391 & \\
\hline Saltzman & 81 & & & & & 1373.148 \\
\hline BA Laid & 84 & & & & & 1440.190 \\
\hline BA 124th & 61 & & & & & 1454.893 \\
\hline Sig. & & 1.000 & .317 & .089 & .719 & .834 \\
\hline
\end{tabular}

Means for groups in homogeneous subsets are displayed.

a Uses Harmonic Mean Sample Size $=88.486$.

b The group sizes are unequal. The harmonic mean of the group sizes is used. Type I error levels are not guaranteed. 


\section{TOTAL SUSPENDED SOLIDS (TSS)}

RANK of TSS

\begin{tabular}{|c|c|c|c|c|c|}
\hline & $\begin{array}{c}\text { Sum of } \\
\text { Squares }\end{array}$ & df & Mean Square & F & Sig. \\
\hline $\begin{array}{c}\text { Between } \\
\text { Groups }\end{array}$ & 21669434.730 & 8 & 2708679.341 & 15.148 & .000 \\
\hline Within Groups & 96023874.538 & 537 & 178815.409 & & \\
\hline Total & 117693309.267 & 545 & & & \\
\hline
\end{tabular}

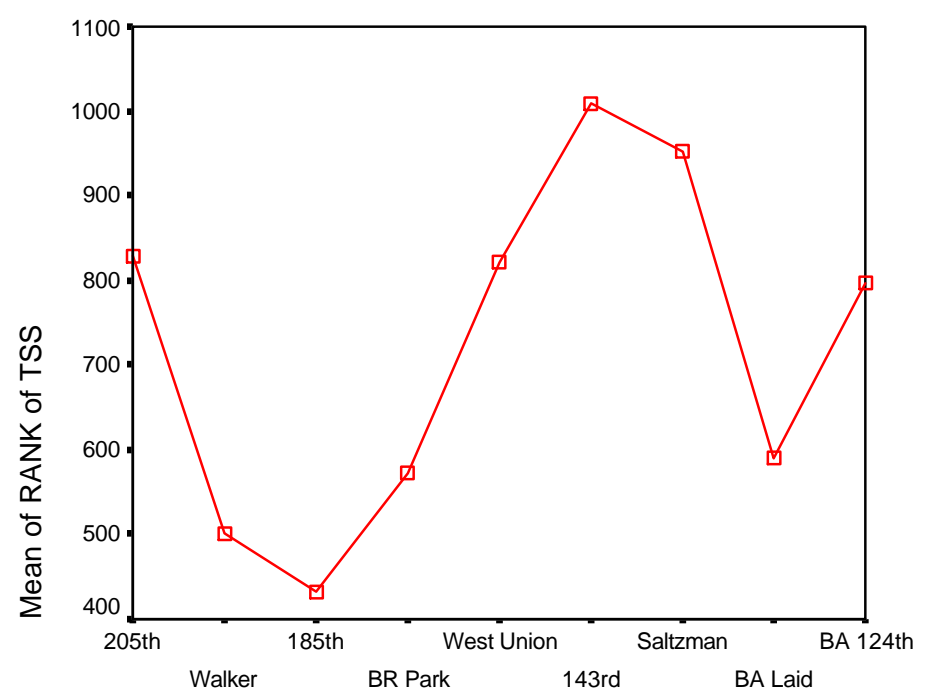

Site number

RANK of TSS

Tukey HSD

\begin{tabular}{|c|c|c|c|c|c|}
\hline & $\mathrm{N}$ & $\begin{array}{c}\text { Subset for } \\
\text { alpha }= \\
.05\end{array}$ & & & \\
\hline $\begin{array}{c}\text { Site } \\
\text { number }\end{array}$ & & 1 & 2 & 3 & 4 \\
\hline 185th & 72 & 432.646 & & & \\
\hline Walker & 66 & 500.758 & & & \\
\hline BR Park & 67 & 572.679 & 572.679 & & \\
\hline BA Laid & 56 & 590.107 & 590.107 & 590.107 & \\
\hline BA 124th & 40 & & 797.475 & 797.475 & 797.475 \\
\hline $\begin{array}{c}\text { West } \\
\text { Union }\end{array}$ & 56 & & & 821.330 & 821.330 \\
\hline 205th & 67 & & & 829.134 & 829.134 \\
\hline Saltzman & 56 & & & & 952.196 \\
\hline 143rd & 66 & & & & 1010.008 \\
\hline Sig. & & .529 & .094 & .057 & .140 \\
\hline
\end{tabular}

Means for groups in homogeneous subsets are displayed.

a Uses Harmonic Mean Sample Size = 58.972.

b The group sizes are unequal. The harmonic mean of the group sizes is used. Type I error levels are not guaranteed. 


\section{Appendix C: Digital GIS Data and Report}

